\title{
Early synaptic imbalance in genetic mice models of Autistic Spectrum Disorders
}

\author{
PhD Thesis \\ in partial fulfilment of the requirements \\ for the degree "Doctor of Philosophy (PhD)" \\ in the Neuroscience Program \\ at the Georg August University Göttingen, \\ Faculty of Biology
}

submitted by

Lucian Medrihan

born in

Bucharest, Romania

Göttingen 2008 
I hereby declare that I wrote this thesis independently, with no other sources and aids than the ones quoted

Göttingen, $27^{\text {th }}$ of March 2008

Lucian Medrihan 
To Marcela 


\section{Abstract}

Autism and Rett Syndrome have been proposed to result from a dysfunction in postnatal or experience-dependent synaptic plasticity. Mice models in which selected candidate genes were mutated were generated and the behavioural phenotype of these mice presents strong similarities with the symptoms of human patients.

Mutations in the X-chromosomal gene that encodes the transcriptional repressor methyl-CpG-binding protein 2 (MeCP2) lead to Rett syndrome, thus MeCP2-mutant mice have been generated to study the molecular mechanisms of the disease. Behavioural abnormalities and the development of disease in the MeCP2 deficient mice are similar to human patients. Various synaptic impairments have been proposed for these mice, however, it remained unclear, which transmitter and receptor systems are predominantly involved, and when in development the cellular defects become apparent.

Neuroligins are a family of cell adhesion proteins involved in synaptic maturation and frequently found to be mutated in autistic patients. Deletions of all neuroligins leads to lethality, thus individual KO mice in which only one isoform was deleted were created in order to investigate the functional role of these proteins. We investigate here postnatal changes in synaptic transmission of neuroligin-1 deficient mice.

Neurobeachin (Nbea) is a multidomain neuron-specific protein, highly expressed in the brain during development. Although the function of Nbea is still unknown, published evidence suggests a role in synaptic membrane protein trafficking. The Nbea gene spans in one of the chromosomal fragile sites with high risk for autism, and the deletion of this gene in mice leads to a lethal phenotype.

Although all these mice models show no obvious neurodegeneration, the mutations always lead to a lethal phenotype, leaving us to investigate if dysfunctions in synaptic maturation and transmission may be the cause of such a dramatic outcome. We restricted our research to postnatal stages, since the ASDs have an interesting development in the first stages of life in human patients. For this, we used as a model brainstem respiratory network, 
a neuronal network that is functional at birth. Our aim is to find common patterns in postnatal maturation of synaptic transmission in these mice models in order to get an insight in the development of ASDs from early stages. 


\section{Table of contents}

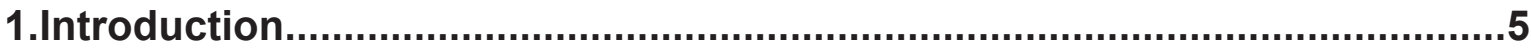

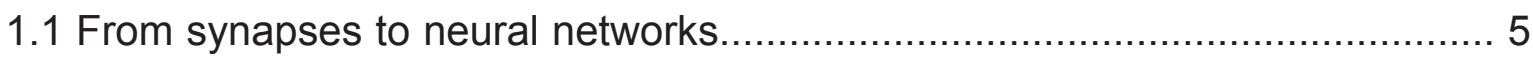

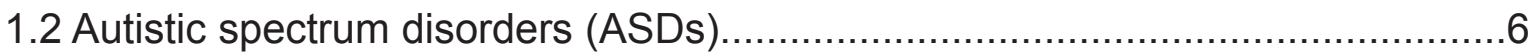

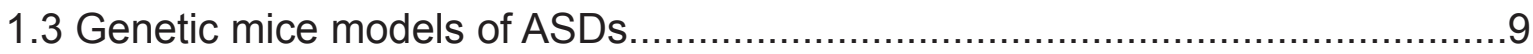

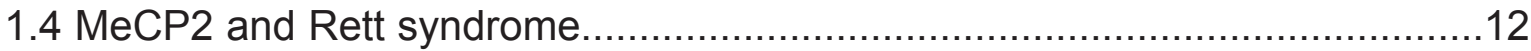

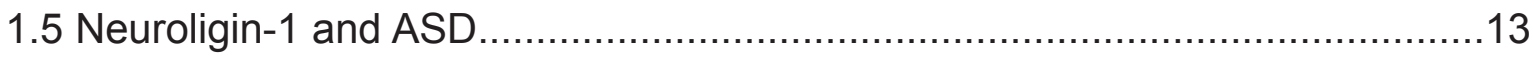

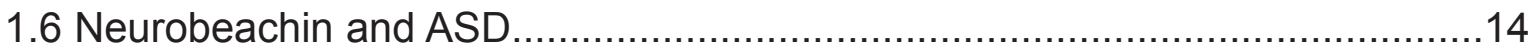

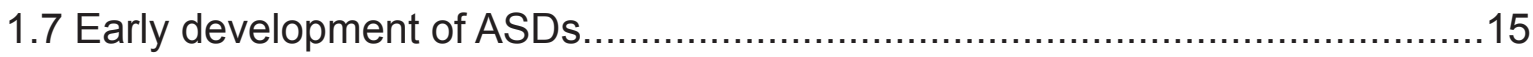

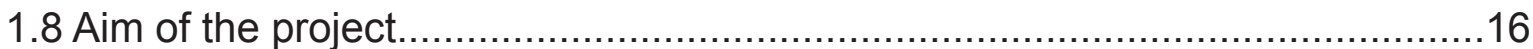

2.Materials and methods............................................................................17

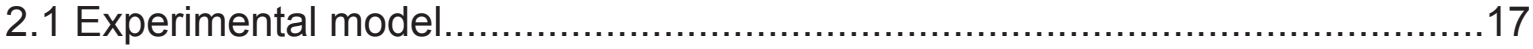

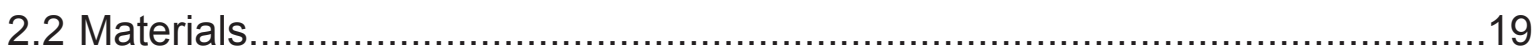

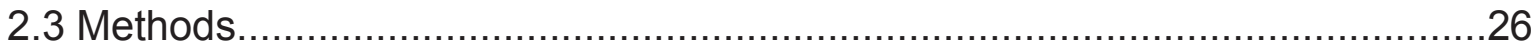

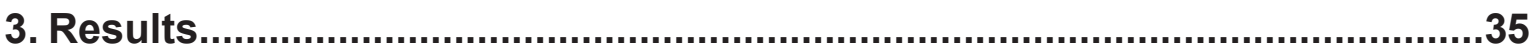

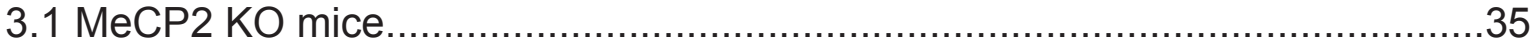

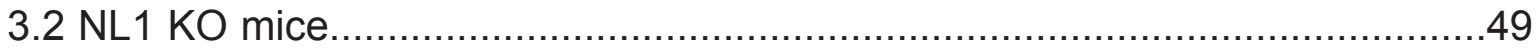

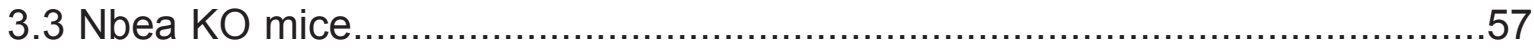

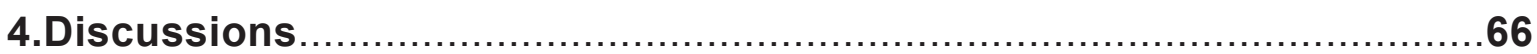

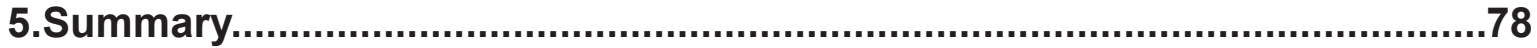

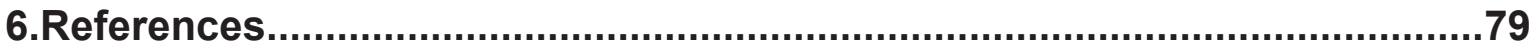

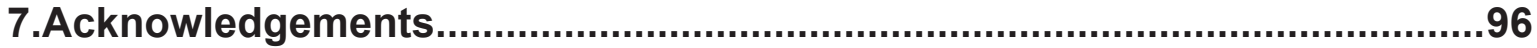

8.Curriculum vitae................................................................................97

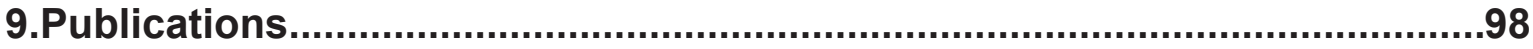




\begin{tabular}{|c|c|}
\hline aa & aminoacid \\
\hline ACSF & artificial cerebrospinal fluid \\
\hline AMPA & $\begin{array}{l}\alpha \text {-amino-3-hydroxy-5-methylisoxazole-4-propionic } \\
\text { acid }\end{array}$ \\
\hline $\mathrm{AP}$ & action potential \\
\hline (D)-AP5 & D-2-amino-5-phosphonopentanoate \\
\hline ASD & autistic spectrum disorder \\
\hline ATP & adenosine triphosphate \\
\hline BSA & bovine serum albumine \\
\hline $\mathrm{CaCl}_{2}$ & calcium chloride \\
\hline CNQX & 6-cyano-7-nitroquinoxaline-2,3-dione \\
\hline CNS & central nervous system \\
\hline EDTA & ethylenediaminetetraacetic acid \\
\hline eEPSC & evoked excitatory postsynaptic currents \\
\hline EGTA & ethylene glycol tetraacetic acid \\
\hline elPSC & evoked inhibitory postsynaptic currents \\
\hline et. al. & and others \\
\hline $\mathrm{Hz}$ & hertz \\
\hline HEPES & $N$-hydroxyethylpiperazine- $N$ '-ethanosulphonic acid \\
\hline HRP & horseradish peroxidase \\
\hline HSP70 & heat shock protein 70 \\
\hline GABA & $\gamma$-aminobutiric acid \\
\hline GABAR & $\gamma$-aminobutiric acid receptor \\
\hline GluR & AMPA receptor \\
\hline GlyR & glycine receptor \\
\hline GTP & guanosine triphosphate \\
\hline $\mathrm{KCl}$ & potassium chloride \\
\hline $\mathrm{kDa}$ & kilodalton \\
\hline $\mathrm{kHZ}$ & kilohertz \\
\hline $\mathrm{KO}$ & knock-out \\
\hline M & molar \\
\hline $\mathrm{mA}$ & miliamper \\
\hline MeCP2 & methyl-CpG-binding protein 2 (MeCP2) \\
\hline mEPSC & miniature excitatory postsynaptic currents \\
\hline
\end{tabular}




\begin{tabular}{|c|c|}
\hline $\mathrm{MgCl}_{2}$ & magnesium chloride \\
\hline$\mu \mathrm{M}$ & micromolar \\
\hline $\mathrm{M} \Omega$ & megaohm \\
\hline mIPSC & miniature inhibitory postsynaptic currents \\
\hline Mint & Munc-18 interacting protein \\
\hline $\mathrm{mM}$ & milimolar \\
\hline $\mathrm{mV}$ & milivolt \\
\hline $\mathrm{nA}$ & nanoamper \\
\hline $\mathrm{NaCl}$ & sodium chloride \\
\hline $\mathrm{NaHCO}_{3}$ & sodium carbonate \\
\hline $\mathrm{NaH}_{2} \mathrm{PO}_{4}$ & sodium posphate \\
\hline Nbea & neurobeachin \\
\hline NGS & normal goat serum \\
\hline $\mathrm{NH}$ & hypoglossal nucleus \\
\hline NL & neuroligin \\
\hline NMDA & $N$-methyl-D-aspartate \\
\hline NMDAR/NR & N-methyl-D-aspartate receptor \\
\hline NMJ & neuromuscular junction \\
\hline $\mathrm{pA}$ & picoamper \\
\hline PAGE & polyacrylamide gel electrophoresis \\
\hline PBC & pre-Bötzinger complex \\
\hline PBS & phosphate buffered saline \\
\hline PCR & polymerase chain reaction \\
\hline $\mathrm{pF}$ & picofarad \\
\hline PFA & paraformaldehide \\
\hline PSD-95 & postsynaptic density protein of $95 \mathrm{kDa}$ \\
\hline RVLM & rostroventrolateral medulla \\
\hline SDS & sodiumdodecylsulphate \\
\hline sEPSC & spontaneous excitatory postsynaptic currents \\
\hline SIPSC & spontaneous inhibitory postsynaptic currents \\
\hline SNAP-25 & synaptosomal-associated protein of $25 \mathrm{kDa}$ \\
\hline SV2 & synaptic vesicle protein 2 \\
\hline TBS & tris borate EDTA buffer \\
\hline TEMED & tetramethylenediamine \\
\hline
\end{tabular}


TKO

TRIS

TTX

VIAAT

VGLUT triple knock-out

tris-(hydroxymethyl)-aminomethan

tetradotoxin

vesicular inhibitory aminoacid transporter

vesicular glutamatergic transporter 


\section{Introduction}

\subsection{From synapses to neural networks}

\subsubsection{Synapses are the communication unit of the neurons}

The term synapse (from Greek, meaning to clasp) was introduced for the first time as a physiological concept by Charles Sherrington in 1897. Synapses are higly asymmetric contact sites between neurons specialized in chemical transmission. The presynaptic site contains a network of scaffolding proteins that ensure the release of the neurotransmitter-containing vesicles into the synaptic cleft, as response to an action potential that reaches the nerve terminal (Südhof, 2004). From the synaptic cleft neurotransmitter binds to specific receptors clustered by postsynaptic scaffolding proteins opposite to the active zone.

There are two categories of chemical transmission between nerve cells, which we refer to as fast and slowsynaptic transmission. Synaptic transmissionat fast synapses occurs in less than $1 / 1000$ of a second and is attributable to the ability of the fastacting neurotransmitters to open ligand-operated ion channels present in the plasma membrane of the postsynaptic cells. In fast excitatory transmission, glutamate opens the glutamate receptors AMPA ( $\alpha$-amino-3-hydroxy-5-methylisoxazole-4-propionic acid) and NMDA ( $\mathrm{N}$-methyl-D-aspartate), which allows positively charged $\mathrm{Na}^{+}$and/ or $\mathrm{Ca}^{2+}$ ions to rush into the cell and causes a depolarizing (excitatory) signal to be generated in the target cell (Hollmann and Heinemann, 1994). In fast inhibitory transmission, GABA or glycine binds to the $\mathrm{GABA}_{\mathrm{A}}$ or glycine receptors, causing a change in the conformation of the receptor, which allows negatively charged chloride ions to permeate the cell and causes a hyperpolarizing (inhibitory) signal to be generated in the target cell (Farrant and Nusser, 2005).

Besides the action-potential-dependent form of neurotransmission there is another form of neurotransmitter release, action-potential-independent, called miniature synaptic transmission. Although discovered first at the neuromuscular junction (Katz, 1969) all synapses manifest spontaneous neurotransmitter release in the absence of presynaptic action potentials. In most cases, these low-probability release events correspond to a single quantum of neurotransmitter that presumably originates from fusion of a single synaptic vesicle (Frerking et al., 1997). As for their functional role, these spontaneous release events are required for signalling leading to maturation and stability of synaptic networks and regulation of local dendritic protein synthesis (McKinney et. al., 1999; Sutton et. al., 2004). In contrast to the highly regulated and precisely timed nature of action-potential-dependent neurotransmitter release, spontaneous synaptic vesicle fusion can only be partially regulated by extracellular 
calcium, and neuromodulators (Angleson and Betz, 2001; Llano et. al., 2000)

\subsubsection{Excitatory/inhibitory balance in neural networks}

The human brain contains approximately $10^{15}$ synapses organized in neural networks. The formation of a synapse, synaptogenesis, it is an extremely complex process, subject of many regulatory factors. After the initial contact between the axonal growth cone and the target neuron, synapses have to assemble at these contacts in the right number, with the correct pre- and postsynaptic molecular composition and spatial distribution (McAllister, 2007). The spatial distribution and cell-specificity of the synapses determine the complexity and operational roles of neural network.

For the proper function of a neural network, one of the most important conditions is the maintaining of a strict balance between inhibition and excitation. One component of the balance is the spatial one, with different networks having different composition in the number of excitatory and inhibitory synapses. For example, in the adult rodent somatosensory cortex the ratio between excitatory and inhibitory synapses is $85.4 \% / 14.6 \%$ (De Felipe et. al., 1997), with similar values (75-95\%/10-25\%) being reported for different cortical areas (Beaulieu et. al., 1994; Micheva and Beaulieu, 1996). In the adult rodent hippocampus the ratio between glutamatergic and GABA synapses changes according to the layer analysed: $94.9 \% / 5.1 \%$ in stratum oriens, $95.8 \% / 4.2 \%$ in stratum radiatum and $84.2 \% / 15.8 \%$ in stratum lacunosum moleculare (Megias et. al., 2001). Besides the spatial component, the temporal (developmental) component of the inhibitory/excitatory balance is as equal as important because it permits activity-dependent plasticity while avoiding excitotoxicity or unstable, seizure-generating activity. For example, at early developmental stages (due to the lack of expression of the $\mathrm{K}^{+}-\mathrm{Cl}^{-}$transporter (KCC2)) immature neurons have a higher intracellular $\mathrm{Cl}^{-}$concentration, thus both GABA and glutamate are excitatory (Ben-Ari et. al., 2004). This early depolarizing GABAergic transmission seems to be important for the future excitatory/inhibitory balance since it was shown that a premature hyperpolarizing shift of GABA leads to disturbances in this balance (Akerman and Cline, 2007). In general, a neural network has to change from a functional, but immature phase, with low frequency firing and slow receptors kinetics to a mature phase in which is able to respond to various high frequency stimuli (Takahashi, 2005; Futai et. al., 2000).

\subsection{Autistic spectrum disorders (ASDs)}

\subsubsection{Features of ASDs}

Autistic spectrum disorders (autism, ASDs) are severe neurodevelopmental 
disorders that affects approximately 1 in 166 born children (DiCicco-Bloom et al, 2006). The modern basis of autism research were set in 1943 by the AustrianAmerican psychiatrist Leo Kanner in a paper that describes the cases of 11 children with inborn autistic features of affective contact (Kanner L., 1943).

According to DSM-IV-TR and ICD-10 by autistic spectrum disorders is understood the spectrum of developmental disorders that comprise impairments in 3 behavioural domains: 1) social interaction, 2) language, communication and imaginative play and 3) range of interest and activities. Children with autism usually fail to develop appropriate interpersonal relationships with their parents or peers, show delay or lack in the development of language, present unusual repetitive behaviours and abnormal interests and activities. In Asperger syndrome, spoken language and non-verbal intelligence are normally developed, however Asperger patients show a stereotyped use of language and inability of sustaining a conversation. Mental retardation is present in $75 \%$ of the patients (Smalley et al., 1997), but there are cases ("autistic savant syndrome") were intelligence is normal.

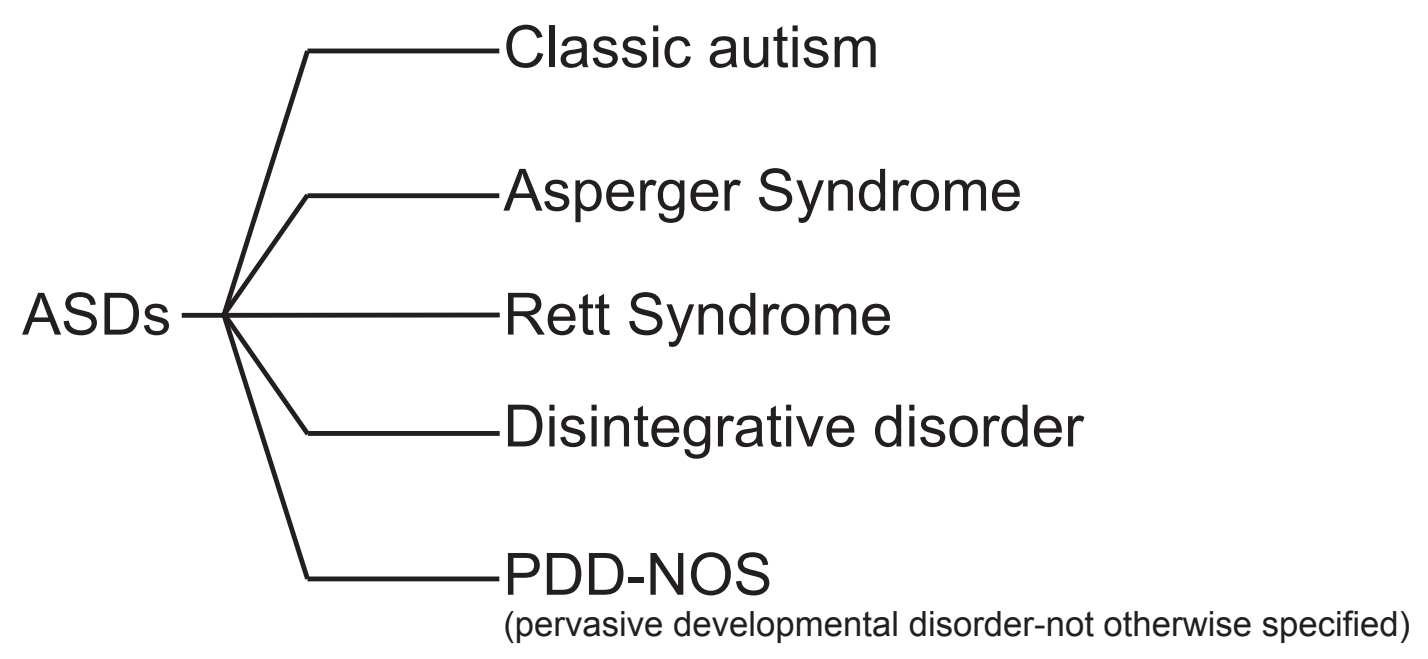

Figure 1.1 Classification of Autistic Spectrum Disorders (ASDs) according to DSM-IV and ICD-10

Anatomical abnormalities have been identified in many brain areas in autistic patients. These include the cerebellum, the brainstem, the cortex, the hippocampus and the amygdala (Courchesne et. al., 2002; Moldin et. al., 2007). Head circumference and MRI studies showed that neonatal brain undergrowth is followed by rapid and excessive brain growth (Courchesne and Pierce, 2005). In terms of neuropathology, the number of Purkinje cells in cerrebelum and is very low (Ritvo et. al., 1986) and the density of packing of neurons in hippocampus and amygdala is increased (Belmonte et. al., 2004). It is believed that local connectivity is favoured over long-range connectivity, probably due to alterations in synapse elimination and/ 
or formation (Belmonte et. al., 2004; Zoghbi et. al., 2004). Based on these data, the current hypothesis is that autism might be caused by an imbalance between excitation and inhibition in key neural systems (Rubenstein and Merzenich, 2003; Polleux and Lauder, 2004).

\subsubsection{Rett Syndrome-a special case of autism}

Rett Syndrome (OMIM, 312750) is a progressive neurodevelopmental disorder that affects mainly girls and the only disorder from the autistic spectrum that is caused by mutations in a single gene, the transcriptional repressor methyl-CpG-binding protein 2 (MeCP2) (Amir et al., 1999; Chahrour et al., 2007). It was first described in 1966 by the Austrian peditrician Andreas Rett (Rett, 1966), but it took almost 20 years until the disorder became recognized in the medical community (Hagberg et al., 1983). RTT patients are supposed to achieve normal developmental milestones until 6-18 months of age when they begin to regress (Hanefeld et al. 1986; Kozinetz et al. 1993). As the disease progresses patients present microcephaly, growth deceleration, weight lose, muscle hypotonia, lost of purposeful movements of hands (Chahrour et al., 2007). Among the autistic features are social withdrawal, loss of language, lack of facial expressivity and eye-to eye communication (Nomura, 2005). Subsequently, patients develop cognitive and motor symptoms, including severe ventilation problems (Hanefeld et al. 1986) that may lead to lethal apnea (Kerr and Burford 2001). Seizures are usually present at the beginning of the disease but they decrease in severity in the teenage years being a minor problem in adulthood (Jian et al., 2006).

\subsubsection{Genetics of ASDs}

One important aspect of ASDs is that the genetic risk is higher than any other neuropsychiatric disorder. Kanner himself noted in his pioneering paper (Kanner L., 1943) that the behaviour of children was abnormal since early infancy, suggesting the presence of an inborn, presumably genetic defect. The concordance between monozygotic twins is more than $90 \%$ and ranges from 10 to $25 \%$ between dyzigotic twins (Ritvo et al., 1985; Bailey et al, 1995). The familial risk of autism ranges from 2.9 to $4.5 \%$ (Bolton et al., 1994; Jorde et al., 1990), a rate 10 times higher than in normal population. Around 15 chromosomal loci have been identified as carrying genes involved in autism (OMIM) and whole-genome screens suggest interactions of at least 10 genes in the causation of autism (Muhle et al., 2006). Until now there is no record of an autistic child having an overtly autistic parent (Folstein, 1977) so epigenetic factors must interfere in the initiation of the disorder. Indeed, several environmental factors like toxic exposures during pregnancy, teratogens, perinatal 
insults and prenatal infections have been associated with autism (Muhle et al., 2006). Thus, we can conclude that ASDs are behaviourally complex disorders with multiple genetic and nongenetic causes that affect early brain development.

In the late years, several linkage studies have managed to enrich the database of genes mutated in autistic patients. Several genes, ranging from transcription factors like MeCP2, ELN, WNT2 and HOXA1 to genes involved in neuronal migration like RELN are mutated in patients of ASDs (Persico and Bourgeron, 2006). However, a review of the genes mutated in autism surprises by the amount of genes that are involved in synaptic maturation and synaptic function, leading researchers to propose that ASDs are disorders of the synapse (Zoghbi, 2004). Special attention has been granted to the NLGN-NRX pathway. NLGN-3 and NLGN-4 have been since several years connected with autism (Jamain et. al., 2003; Laumonier et. al., 2004), but recently mutation in the NRX gene, the transynaptic partner of neuroligins (The International Autism Consortium, 2007) and in SHANK-3, a postsynaptic scaffolding protein that binds indirectly to neuroligins (Durand et. al., 2007) lead to the hypothesis that at least $1 \%$ of the autism cases are produce by mutation in the NLGN-NRX pathway (DiCicco-Bloom et. al., 2007). Other genes involved in synaptic function and autism are the gene encoding Nbea (Castermans et. al., 2003), a protein of neuronal membranes or the gene encoding NrCAM, a cell adhesion molecule involved in neuronal migration (Persico and Bourgeron, 2006). A large amount of mutated genes are encoding for neurotransmitter and postsynaptic receptors. Among them are genes that encodes for the serotonin transporter 5-HTT and one subunit of the serotonin receptor, 5-HT2A, GABR3, a gene that encodes for the $\beta 3$ subunit of $\mathrm{GABA}_{\mathrm{A}}$ receptor, or genes encoding for glutamate receptor subunits like GRIN2A or GRIK2 (Persico et. Bourgeron, 2006; Muhle et. al., 2004). These are all genes involved in synaptic transmission, thus suggesting that at least one of the underlieng mechanism of autism would be a functionally impaired synapse.

\subsection{Genetic mice models of ASDs}

In recent years, a new field is emerging in the autism research: behavioural genetics. The aim is to bring autism to an experimental level by creating mice models that mimic the behavioural traits of the autistic patients. However, given the multifactorial origin of autism and its great symptomatic diversity, to create a mouse model that captures all of the features of ASDs seems an impossible task. One more reasonable approach was to focus on single features of ASDs and then study the underlying mechanism of the respective feature. In the case of the genetic mice models, genes considered important for ASDs are mutated, deleted or overexpressed in mice in order to study the consequences of their dysfunction in the assembly of the whole 
organism. The importance of these studies is tremendous and they show for the first time that the loss-of-function of one gene alone can be enough to produce autisticlike symptoms in mice without the intervention of environmental factors.

\subsubsection{MeCP2 mice}

Several lines of genetically engineered MeCP2 mice have been generated to study the cellular and molecular mechanisms of Rett syndrome (Chen et. al., 2001; Guy et. al., 2001; Shahbazian et. al., 2002; Collins et. al., 2004; Pelka et. al., 2005). In these lines the exons 3 and 4 of the MeCP2 gene were completely deleted on a normal (MeCP2-/y; Guy et al. 2001) or an XO background (MeCP2-/O; Pelka et. al., 2006), deleted only in the forebrain (MeCP2 ${ }^{\mathrm{Cre}}$; Chen et. al., 2001), or truncated (MeCP2 ${ }^{308 / y}$; Shahbazian et. al., 2002). Similar to patients, the MeCP2-mutant mice are apparently normal until some developmental stage, when they begin to exhibit Rett-like symptoms: abnormal motor and social behavior, including respiratory irregularities, seizures, hypoactivity etc. (see Table 1.1). Since morphological alterations in brain architecture are subtle in the MeCP2 lines, most studies have focused on functional impairments to explain their profound behavioural abnormalities. In Table 1.1 we

Table 1.1. Behavioural and neurophysiologichal features of available MeCP2 mice lines.

\begin{tabular}{|c|c|c|}
\hline Mouse line & Behavioural features & $\begin{array}{c}\text { Neurophysiologichal } \\
\text { features }\end{array}$ \\
\hline $\begin{array}{c}\text { MeCP2 -ly } \\
\text { (Guy et. al., } \\
\text { 2001) }\end{array}$ & $\begin{array}{l}\text { - onset of phenotype at } \\
\text { 3-6 weeks } \\
\text { - uncoordinated gait, } \\
\text { hypoactivity, tremor, } \\
\text { respiratory dysrhytmia, } \\
\text { apnea } \\
\text { - death at } 10 \text { weeks }\end{array}$ & $\begin{array}{l}\text { - } \text { reduced LTP in cortical } \\
\text { slices (Asaka et. al., } \\
2006) \\
\text { - decrease mEPSC } \\
\text { frequency in } \\
\text { hippocampal cultures } \\
\text { (Nelson et. al., 2005) } \\
\text { - decrease mEPSC } \\
\text { frequency in autaptic } \\
\text { cultures accompanied } \\
\text { by a decrease in } \\
\text { glutamatergicsynapses } \\
\text { (Chao et. al., 2007) }\end{array}$ \\
\hline
\end{tabular}




\begin{tabular}{|c|c|c|}
\hline $\begin{array}{l}\text { MeCP2 Cre } \\
\text { (Chen et. al., } \\
\text { 2001) }\end{array}$ & $\begin{array}{l}\text { - onset of phenotype at a } \\
\text { later age } \\
\text { - gait ataxia, increased } \\
\text { anxiety, impaired social } \\
\text { behaviour }\end{array}$ & $\begin{array}{l}\text { - decrease in excitatory } \\
\text { input and increase in } \\
\text { inhibitory input in cortex } \\
\text { (Dani et. al., 2005) }\end{array}$ \\
\hline $\begin{array}{l}\text { MeCP2 } \\
\text { (Shandy } \\
\text { et. al., 2002) }\end{array}$ & $\begin{array}{l}\text { - onset of phenotype at } 6 \\
\text { weeks } \\
\text { - motor dysfunctions, } \\
\text { hypoactivity, seizures, } \\
\text { impaired social } \\
\text { behaviour, increased } \\
\text { anxiety, learning and } \\
\text { memory deficits } \\
\text { dies at } 15 \text { months }\end{array}$ & $\begin{array}{l}\text { - } \text { reduced LTP in cortical } \\
\text { and hippocampal slices } \\
\text { ( Moretti et. al., 2006) }\end{array}$ \\
\hline $\begin{array}{l}\text { MeCP2 }^{\mathrm{Tg}} \\
\text { (Collins et. } \\
\text { al., 2004) }\end{array}$ & $\begin{array}{l}\text { - onset of phenotype at } \\
10 \text { weeks } \\
\text { - initial enhancement } \\
\text { in motor and learning } \\
\text { abilities } \\
\text { - } \mathrm{h} \text { y p o a c t i v i t y, } \\
\text { agressivenes, seizures, } \\
\text { motor dysfunctions } \\
\text { - dies at } 1 \text { year }\end{array}$ & 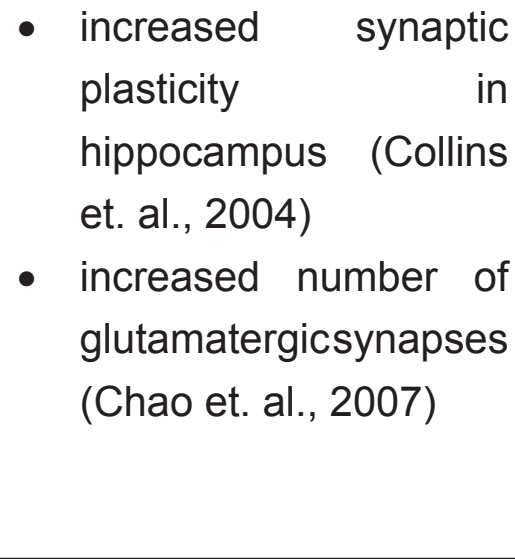 \\
\hline $\begin{array}{l}\text { MeCP2 }^{-/ o} \\
\text { (Pelka et. al., } \\
\text { 2006) }\end{array}$ & $\begin{array}{l}\text { - hypoactivity, learning } \\
\text { deficits and reduced } \\
\text { anxiety }\end{array}$ & - no data \\
\hline
\end{tabular}

review behavioural and neurophysiological findings in these mice lines. Although these studies found opposite effects of MeCP2 on excitatory versus inhibitory neurotransmission, it appears likely that an imbalance of synaptic activity is a crucial aspect of the phenotype.

\subsubsection{Neuroligin mice}

As described above, NLGN3 and NLGN4 genes have been associated with autism (Jamain et. al., 2003; Laumonnier et. al., 2004). Tabuchi et. al. (2007) introduced the R451C (arg451 to cys) substitution in neuroligin-3 into mice. R451C mutant 
mice showed impaired social interactions but enhanced spatial learning abilities. At a synaptic level these behavioural changes were accompanied by an increase in inhibitory synaptic transmission with no apparent effect on excitatory synapses. The R451C substitution represents a gain-of-function mutation since the deletion of neuroligin-3 did not cause such changes. Tabuchi et. al. (2007) concluded that increased inhibitory synaptic transmission might contribute to human autism spectrum disorders. A mutant mouse lacking the murine ortholog of human NL-4 presents even more autistic-like features (Jamain, 2008). The NL $-4 \mathrm{KO}$ mice show impaired social interaction with other mice and reduced vocalization in the presence of female mice. Moreover, NL-4 mice show reduction in the total brain size and that is the key anatomical finding in autistic patients. The specific regions that are reduced in size, cerrebelum and brainstem, are regions previously shown to have a reduced size in autistic patients.

\subsection{MeCP2 and Rett syndrome}

\subsubsection{MeCP2 is a transcriptional repressor}

MeCP2 was identified as a mammalian protein that binds methylated CpG dinucleotides (Lewis et. al., 1992) leading to repressed transcription in vitro (Nan et. al., 1997). The protein is composed of three domains: the MDB (methyl-binding domain), the TRD (transcriptional repressor domain) and a C-terminal domain (Chahrour and Zoghbi, 2007). MDB binds to the methylated CpGs of target genes and TRD recruits the corepressor Sin3A and histone deacetylases (HDAC 1 and 2) leading to compaction of chromatin and inhibition of transcription (Jones et. al., 1998; Nan et. al., 1998). The transcriptional repressor activity of MeCP2 can be also through direct interaction between its C-terminal domain and chromatin (Nikitina et. al., 2007). As for the importance of different domains in the context of Rett Syndrome, it has been shown that mutation in all domains cause the disorder, although the severity of the disorder may vary (for example, mutations in the C-terminal domain have been associated with milder symptoms of RTT patients. (Christodoulou et. al., 2003; Chahrour et. al., 2007).

\subsubsection{MeCP2 is involved in synaptic development}

Based on the temporal expression patterns of MeCP2 it has been hypothesised that the main function of the protein is to modulate the activity of genes involved in synaptic development (Shahbazian et. al., 2002, Johnston et. al., 2001). MeCP2 levels are low during embryogenesis and they are progressively increasing with the postnatal neuronal maturation (Balmer et. al., 2003; Kishi et. al., 2004; Matarazzo et. 
al., 2003; Mullaney et al., 2004; Shahbazian et. al., 2002). For example, in olfactory receptor neurons (ORNs) high expression levels of MeCP2 are connected with maturation and they precede the onset of synaptogenesis (Matarazzo et. al., 2003). In cortex expression of MeCP2 is increased within each layer during the formation of the respective layer and synaptogenesis (Mullaney et. al., 2004). Recent data from $\mathrm{KO}$ mice support the synaptic functions of MeCP2. In general, although changes in brain morphology are subtle in KO mice they present several impairments in synaptic transmission and plasticity (see Table 1.1). Moreover, deletion of MeCP2 in mice leads to delay in neuronal maturation and synaptogenesis (Fukuda et. al., 2004). A role in synaptogenesis for MeCP2 it is implied also by its target genes, since its transcriptional repression is localized at specific promoters crucial to brain development and plasticity, including those regulating levels of brain-derived neurotrophic factor (BDNF), the transcription factor distal-less homeobox 5 (DLX5), ubiquitin-protein ligase E3A (UBE3A) and the GABA receptor subunit GABRB3 (Chahrour et. al, 2007).

\subsection{Neuroligin-1 and ASD}

\subsubsection{Function of Neuroligin-1}

Neuroligins (NLs) are cell adhesions postsynaptic proteins that interact with the presynaptic $\alpha$ - and $\beta$-neurexins (Ichtchenko et al., 1995; Song et. al., 1999; Boucard et. al., 2005). The neuroligin family comprises 4 genes in rodents (NLGN1-4) and 5 members in humans and higher primates (NLGN1-3, NLGN4X and NLGN4Y) (Ichtchenko et al., 1995; Jamain et. al., 2003). It has been proposed that NLs, along with their transsynaptic partners, neurexins, act as transneuronal signals and recrute the synaptic component necessary for the synaptic formation (Craig and Kang, 2007). NL-1 expressed in HEK293 cells cocultured with neurons induces presynaptic differentiaon at the site of contact (Scheiffele et. al., 2000; Boucard et. al., 2005; Chih et. al., 2006). It was shown that different members of the family localize at different type of synapses. While NL-2 localize at inhibitory synapses (Varoqueaux et. al., 2004), NL-1 has been associated with excitatory synapses (Song et. al., 1999). Overexpression of NL-1 in neurons leads to increased density of excitatory synapses and clustering of postsynaptic excitatory components accompanied by increase in the frequency and amplitude of miniature excitatory currents (Dean et. al., 2003; Chih et. al., 2005). These data suggest a role for NLs in synaptic formation, however deletion of all major NLs in mice didn't lead to changes in synaptic density (Varoqueaux et. al., 2006). On the other hand, NL TKOs show a severe reduction in both excitatory and inhibitory spontaneous currentssuggesting that NLs play an 
essential role in maintaining the proper function of synapses (Varoqueaux et. al., 2006). Recent research (Chubykin et. al., 2007) shows that deletion of NL-1 in mice results in changed AMPA/NMDA ratio and proposes a role for NL1 in the activitydependent maturation of NMDA synapses.

\subsubsection{NLs and autism}

The connection between neuroligins and autism started in 2003 with the finding that mutations of NL-3 and NL-4 were found in two brothers with ASD (Jamain et. al., 2003). Other mutations in the NL-3 and NL-4 genes were subsequently found (Laumonnier et. al., 2004; Yan et. al., 2004). Recent studies (The Autism Consortium Project, 2007) show the binding partners of neuroligins, neurexins to be candidate genes for autism. A mutation in Shank-3, a scaffolding protein that binds indirectly with NL, was also found in autistic spectrum disorders (Durand et. al., 2007). Thus, mutations in the NL-NRX pathway seem to be one cause of ASDs. Indeed, reproduction of the NL-3 mutations (Tabuchi et. al., 2007) or deletion of NL-4 (Jamain et. al., 2008) leads to autistic-like behaviours in mice. NL-1, the protein that is the object of our present study has not been mutated in ASDs. However, since neuroligins seem to exercite similar functions at different synapses (Dean et. al., 2003; Chih et. al., 2005; Chubykin et. al., 2007) analysis of the NL-1 KO may bring informations about the exact mechanism through which mutations in this family of proteins lead to ASDs.

\subsection{Neurobeachin and ASD}

\subsubsection{Structure and function of Nbea}

Neurobeachin was initially discovered as a component of neuronal synapses. The protein is 3000 a.a. long and is peripherally associated with polymorphic tubulocisternal endomembranes and a minority of postsynaptic plasma membranes (Wang et al., 2000). In particular, neurobeachin concentrates at trans-Golgi-near membranes, and its membrane association is stimulated by GTP and antagonized by brefeldin A (Wang et al., 2000). These circumstances suggest a functional link with a GTP-dependent vesicle coat and an involvement in the post-Golgi sorting or targeting of neuronal membrane proteins, including proteins of postsynaptic plasma membranes. Whereas neurobeachin expression seems to be restricted to neurons and endocrine cells, an isoform expressed in many tissues, Lrba, was discovered as a gene product whose expression is upregulated in B cells and macrophages in response to bacterial lipopolysaccharides (Wang et al., 2001). Neurobeachin but not Lrba can bind the regulatory subunit RII of protein kinase A, qualifying it as an AKAP (A-kinase anchor protein) (Wang et al., 2000). 
Introduction

\subsubsection{Nbea null-mouse}

The importance of neurobeachin for the functioning of the nervous system is underscored by the severe phenotype of mouse mutants. A Nbea null mutant mouse was obtained by coincidental insertion mutagenesis (Su et al., 2004). Homozygous Nbea (-/-) mice were found to die immediately after birth from breathing paralysis, due to a complete block of evoked synaptic transmission at the neuromuscular synapse (NMS) whereas nerve conduction, NMS morphology and spontaneous synaptic vesicle release were normal. Electrophysiological analysis of neuromuscular transmission in these mice indicated that the defect was presynaptic, most likely affecting either action potential invasion of nerve terminals or the coupling of action potential invasion to calcium-dependent neurotransmitter exocytosis. Brain cytoarchitecture of the Nbea mutant mice was apparently normal, but a functional analysis of neuro-neuronal synapses was not carried out (Su et al., 2004). Neurobeachin appears to be expressed pan-neuronally (Wang et al., 2000), suggesting that it is functionally important not only in motoneurons but throughout the nervous system.

\subsubsection{Nbea and ASD}

The human neurobeachin gene (NBEA) is large (580 kbp, 57 exons) and contains a region of enhanced chromosomal fragility (Savelyeva et al., 2006). A heterozygous rearrangement of NBEA was characterized in a patient with autism (Castermans et al., 2003), and in three other autism cases chromosomal deletions in the NBEA region were identified (Smith et al., 2002; Barrett et al., 1999; Ritvo et al., 1988). The above findings implicate neurobeachin as one genetic factor that can contribute to the etiology of ASD.

\subsection{Early development of ASDs}

Perhaps the most surprising observation in the field of autism research is that for this disorder of neural development, there are very few studies of early neural development. The genetic and developmental processes that organize developing brain networks and presumably are dysfunctional in the autistic brains are largely unstudied in the early developmental time period in both human patients and mice models of the disorder. For instance, in the case of Rett Syndrome, both RTT patients and MeCP2-mutant mice are born normally and show a period of apparently undisturbed postnatal development before clinical symptoms become obvious. However, it is probable that mild symptoms appear earlier since the expression of MeCP2 in normal brains starts already during the embryonic development, and reaches a peak in many brain regions before the onset of related symptoms 
Introduction

(Shahbazian et al., 2002; Mullaney et al., 2004). Clinical research has begun to emphasize the problems of young RTT and autistic patients (Einspieler et al. 2005; Nomura 2005; Trevarthen and Daniel 2005). The analysis of home made videos of girls later diagnosticized with Rett showed that abnormal hand movements and sleep disturbances are detectable from the first 4 months of life (Einspieler et. al., 2005; Nomura, 2005). Impairments in social behaviour appear on video at 11 months in an autistic patient (Trevarthen and Daniel 2005). Consistently, studies on young MeCP2deficient mice revealed that more subtle behavioural alterations might be present early in development. Picker et. al. (2006) shows that starting with postnatal day 5 MeCP2 null mice exhibit dramatic increases in ultrasonic vocalizations in response to social isolation. Other abnormalities of younger mice are hypoactivity, delay in the acquisition of postural reflexes and impaired growth maturation, abnormalities that resemble symptoms of RTT girls (Santos et al. 2007). Moreover, glutamatergic synapses in MeCP2 KO mice are altered in autaptic cultures and in vivo in the first 2 weeks of development (Chao et. al., 2007) indicating that cellular symptoms may be present in these mice much earlier than it was believed. Thus, a more thoroughly investigation of early developmental events in both human patients and mice models could bring more insight about the mechanistic of this terrible disorder.

\subsection{Aim of the project}

We started this project shortly after the first article that proposed that autistic spectrum disorders are disorders of the synapse (Zoghbi, 2003). Since then there has been a lot of work published in the field of autism research, but still most of the questions remain open. In this project we investigated the effect on synaptic function induced by the deletion in mice of three proteins (MeCP2, NL-1 and Nbea) associated with ASDs and with synaptic development. Our approach was novel because we choose to investigate the mice models early in development, in the first postnatal week. Two main questions guided us during this project:

When does the synaptic imbalance appears in our mice models and which transmitter systems are affected?

What structural impairments of synaptic components are the underlying causes of the functional imbalance? 


\section{Materials and methods}

\subsection{Experimental model}

To investigate the early synaptic dysfunctions in our mice models we studied neurotransmission in the respiratory brainstem network. Normal synaptic transmission and development has extensively been characterized in this brainstem model (Ritter and Zhang 2000) and various defects of synaptic function have been successfully studied in this system (Missler et al. 2003; Varoqueaux et al. 2006; Zhang et al. 2005).

We had particular reasons for choosing the respiratory brainstem network as a

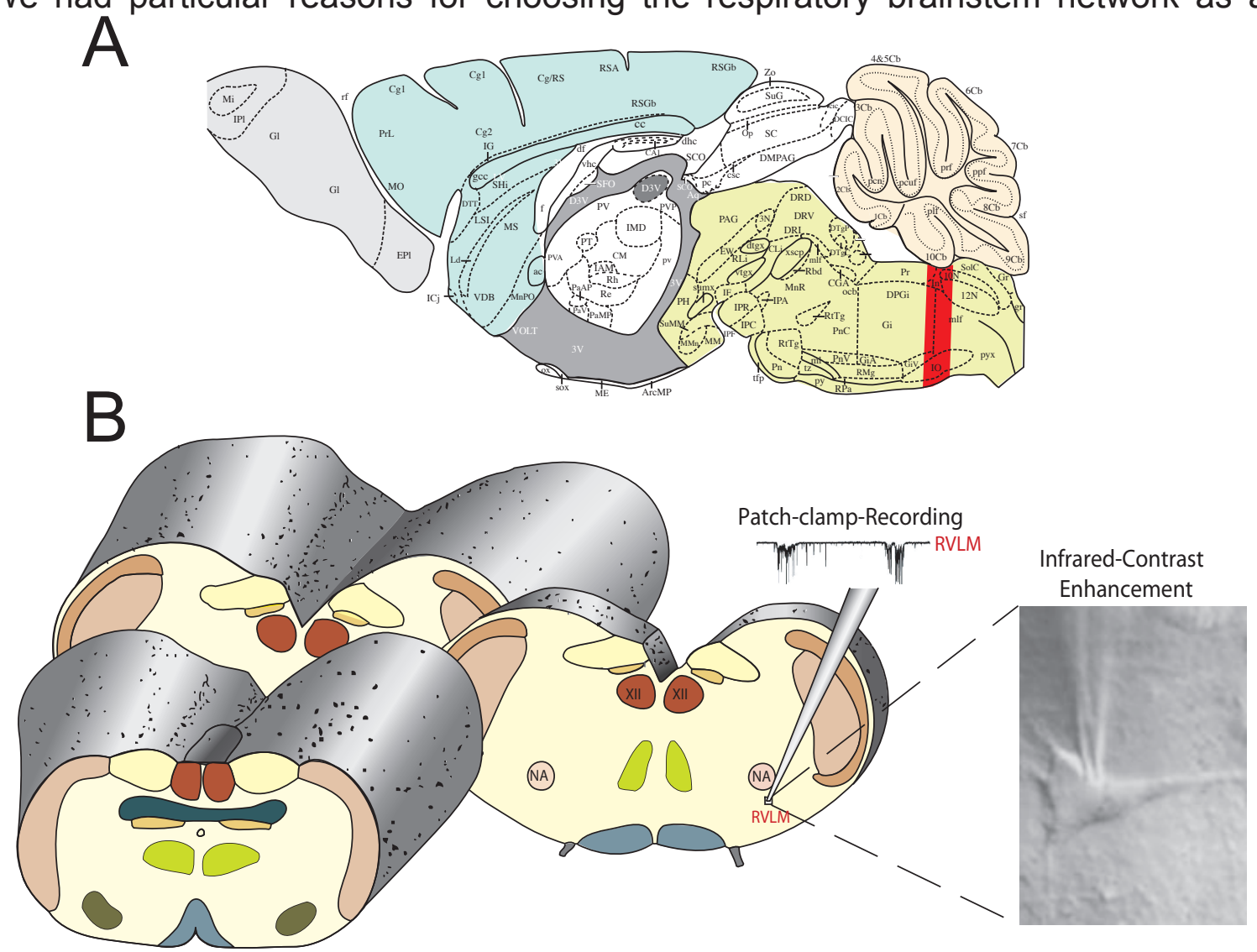

Figure 2.1 Respiratory brainstem network in mice. (A) Schematic sagital view of the mice brain (Franklin and Paxinos, 1997). (B) Slice from the respiratory medulla (in red in (A)) with the main nuclei. NA, nucleus ambiguous; RVLM, rostroventrolateral medulla; XII, hypoglossus nucleus. (B) Infrared contrast enhaced image from a patched neuron in RVLM

working model in the case of each mutant mouse analysed in the present work. The resting ventilation activity is strongly impaired in adult MeCP2-deficient mice (Stettner et al. 2007; Viemari et al. 2005) at least partly due to impaired synaptic function (Stettner et al. 2007). Thus, in the case of MeCP2 KO mice, we chose this model in order to look for early signs of impairments in ventilation and its underlying network activity. For the NL-1 KO mice, we chose this model because the NL TKO 
mice died at birth due to respiratory failure (Varoqueaux et. al., 2006) and we wanted to compare the role of NL-1 in comparison with other neuroligins. As for Nbea KO mice, since they die at birth, the respiratory brainstem network was the most appropiate to investigate the causes of the lethal phenotype.

We recorded neurons in the rostroventrolateral medulla (RVLM), an area of the reticular brainstem formation, that contains pre-Bötzinger complex (PBC), (Fig. 2.1) a neuronal network responsible for generating the respiratory rhythm (PBC, c.f. Richter and Spyer 2001). No further characterization of these neurons was performed in order to test whether these are inspiratory or other respiratory neurons, but, as Smith et. al. (1991) describes it, majority of neurons from RVLM are involved in ventilation.

To ensure that the observed phenotypes are not particular to RVLM neurons we extended our experiments to neurons from the hypoglossal nucleus (NH) (Fig. 2.1), a nucleus that synchronises with the firing of neurons in PBC (Tokumasu et. al, 2001) and controls movements of the tongue (Lowe et al, 1980). Neurons from $\mathrm{NH}$ receive mixed inhibitory and excitatory inputs from the ipsilateral PBC neurons ( $\mathrm{Li}$ et. al, 2003). 


\subsection{Materials}

\subsubsection{Equipment}

\section{Devices}

\begin{tabular}{ll}
\hline Name & Manufacturer \\
\hline $\begin{array}{l}\text { Differential pressure transducer (CD15 } \\
\text { Carrier Demodulator) }\end{array}$ & ValiDyne Engineering, USA \\
Vibratome slicer (752M Vibroslice) & Campden Ilnstruments, UK \\
Water pump (505LA) & Watson Marlow, USA \\
Water bath (D8) & Haake, Germany \\
Pipette puller (P87) & Sutter Instrument Co., USA \\
Light microscope (Axioscope 2 FSplus) & Zeiss, Germany \\
Patch-clamp amplifier (WPC-100) & E.S.F. electronic, Germany \\
Micromanipulator (1 MM3A) & Kleindiek nanotechnik, Germany \\
Isolated pulse stimulator (M2100) & A-M systems Inc., USA \\
Pressure ejector (PDES-2L) & NPI electronic, Germany \\
A/D converter (Digidata 1322) & Molecular Devices, USA \\
Confocal microscope (LSM 510 Meta) & Zeiss, Germany \\
Cryoscopic osmometer (Osmomat 030) & Gonotec, Germany \\
Electrophoresis power supply (EPS601) & Amersham Biosciences, Germany \\
WB ECL detection system (Chemi- & Vilber Lourmat, France \\
Smart 5000) & \\
\hline
\end{tabular}

\section{Additional materials}

\begin{tabular}{ll}
\hline Name & Manufacturer \\
\hline $\begin{array}{l}\text { Borosilicate glass micropipettes (GF150- } \\
\text { 10F) }\end{array}$ & Clark Electromedical Instruments, UK \\
Membrane hybond ECL & Amersham Biosciences, Germany \\
Whatman GB58 Blotting paper B002 & Heinemann Labortechnik GmbH, \\
& Germany \\
Hamilton syringe & Hamilton, USA \\
Microscope slides & Menzel-Gläser, Germany \\
\hline
\end{tabular}


Software

\begin{tabular}{ll}
\hline Use & Name and manufacturer \\
\hline Patch-clamp recording and analysis & pClamp 9.2, Molecular Devices, USA \\
Western analysis & MiniAnalysis, SynaptoSoft, USA \\
Microscopy analysis & Bio-1D, Vilber Lourmat, France \\
& Zeiss analysis software, Zeiss, \\
Statistics & Germany \\
& Instat 3, GraphPad Software Inc., \\
& USA \\
& Prism 4.0, GraphPad Software Inc., \\
Figures and tables & USA \\
& Prism 4.0, GraphPad Software Inc., \\
& USA \\
Text processing & Adobe Illustrator CS, Adobe, USA \\
& Microsoft Excel, Microsoft Corp., USA \\
& Adobe Photoshop CS, Adobe, USA \\
\hline Image processing & Microsoft Word, Microsoft Corp., USA \\
& Adobe InDesign CS, Adobe, USA \\
\hline
\end{tabular}

\subsubsection{Drugs and solutions}

2.2.2.1 Chemicals

\begin{tabular}{ll}
\hline Name & Manufacturer \\
\hline Acetic acid & Merck, Germany \\
AA30/rotiphorese gel 30 & Roth, Germany \\
Agarose & Merck, Germany \\
AMPA & Tocris, UK \\
(DL)-AP5 & Tocris, UK \\
Aprotinin A 1153 & Sigma-Aldrich, Germany \\
Bicuculline & Sigma-Aldrich, Germany \\
BSA & Amersham Pharmacia Biotech, UK
\end{tabular}


$\mathrm{CaCl}_{2}$

$\mathrm{CaCl}_{2} \times 2 \mathrm{H}_{2} \mathrm{O}$

Coomassie Brilliant Blue

CNQX

EGTA

EDTA

Ethanol

(D)-Glucose

Glycine

HEPES

$\mathrm{KCl}$

Leupeptin L 9783

(ß)-Mercaptoethanol

Methanol

$\mathrm{MgCl}_{2}$

$\mathrm{MgCl}_{2} \times 6 \mathrm{H}_{2} \mathrm{O}$

Mowiol

Muscimole

$\mathrm{Na}_{3}$ ATP

$\mathrm{NaCl}$

$\mathrm{Na}_{3}$ GTP

$\mathrm{NaHCO}_{3}$

$\mathrm{NaH}_{2} \mathrm{PO}_{4}$

$\mathrm{Na}_{2} \mathrm{HPO}_{4} \times 12 \mathrm{H}_{2} \mathrm{O}$

NGS

NMDA

PFA

Poinceau S

SDS

Strychnine

TEMED

TRIS

TritonX100
Roth, Germany

Sigma-Aldrich, Germany

Merck, Germany

Tocris, UK

Sigma-Aldrich, Germany

Sigma-Aldrich, Germany

Calbiochem, USA

Roth, Germany

Roth, Germany

Sigma-Aldrich, Germany

Sigma-Aldrich, Germany

Sigma-Aldrich, Germany

Sigma-Aldrich, Germany

Roth, Germany

Sigma-Aldrich, Germany

Sigma-Aldrich, Germany

Calbiochem, USA

Tocris, UK

Sigma-Aldrich, Germany

Roth, Germany

Sigma-Aldrich, Germany

Roth, Germany

Roth, Germany

Roth, Germany

Sigma-Aldrich, Germany

Tocris, UK

Roth, Germany

Sigma-Aldrich, Germany

Roth, Germany

Sigma Aldrich

Roth, Germany

Roth, Germany

Roth, Germany 
TTX

Alomone Labs, Israel

Tween 20

Roth, Germany

\subsubsection{Solutions}

\section{For electrophysiology}

Extracellular solution (ACSF):

$118 \mathrm{mM} \mathrm{NaCl}, 3 \mathrm{mM} \mathrm{KCl}, 1.5 \mathrm{mM} \mathrm{CaCl} 2,1 \mathrm{mM} \mathrm{MgCl}, 25 \mathrm{mM} \mathrm{NaHCO}{ }_{3}, 1 \mathrm{mM}$ $\mathrm{NaH}_{2} \mathrm{PO}_{4}, 5 \mathrm{mM}$ glucose

INK intracellular solution:

$140 \mathrm{mM} \mathrm{KCl}, 1 \mathrm{mM} \mathrm{CaCl}$, $10 \mathrm{mM}$ EGTA, $2 \mathrm{mM} \mathrm{MgCl}$, $4 \mathrm{mM} \mathrm{Na}{ }_{3}$ ATP, $0.5 \mathrm{mM}$ $\mathrm{Na}_{3} \mathrm{GTP}, 10 \mathrm{mM}$ HEPES

INTEA intracellular solution:

$110 \mathrm{mM} \mathrm{CsCl}, 30 \mathrm{mM}$ TEA-Cl, $1 \mathrm{mM} \mathrm{CaCl}, 10 \mathrm{mM}$ EGTA, $2 \mathrm{mM} \mathrm{MgCl}, 4 \mathrm{mM}$ Na3ATP, $0.5 \mathrm{mM} \mathrm{Na}_{3}$ GTP, $10 \mathrm{mM}$ HEPES

\section{For biochemical procedures}

Homogenization buffer:

$320 \mathrm{mM}$ sucrose, $5 \mathrm{mM}$ Hepes-NaOH ( $\mathrm{pH}$ 7.4), $0.1 \mathrm{mM}$ EDTA, proteases inhibitors (aprotinin, leupeptin)

Stacking gel buffer (Upper Tris):

$0.5 \mathrm{M}$ Tris (pH 6.8); $0.4 \%$ SDS

Separation gel buffer (Lower Tris):

$1.5 \mathrm{M}$ Tris (pH 8.8); 0.4\% SDS

10x SDS-PAGE-running buffer (for $1 \mathrm{~L}$ ):

$30.2 \mathrm{~g}$ Tris- $\mathrm{HCl} ; 144 \mathrm{~g}$ Glycine; $10 \mathrm{~g}$ SDS

10x Transfer buffer (for $1 \mathrm{~L}$ ):

$31.2 \mathrm{~g}$ Tris- $\mathrm{HCl} ; 144 \mathrm{~g}$ Glycine; $5 \mathrm{~g}$ SDS

$1 x$ Transfer buffer (for $100 \mathrm{ml}$ )

$10 \mathrm{ml} \mathrm{10x}$ transfer buffer; $20 \mathrm{ml}$ methanol; $70 \mathrm{ml} \mathrm{H}_{2} \mathrm{O}$ 
Ponceau-S solution (for $1 \mathrm{I}$ ):

2 g Ponceau-S; $50 \mathrm{ml}$ Acetic acid, $950 \mathrm{ml} \mathrm{H}_{2} \mathrm{O}$

$10 \times$ TBS buffer:

1.37 M NaCl, 200 mM Tris- $\mathrm{HCl}(\mathrm{pH} 7.6)$

1x TBS -Tween 20 buffer (for $1 \mathrm{~L}$ )

$100 \mathrm{ml}$ TBS, $900 \mathrm{ml} \mathrm{H}$ 0, $1 \mathrm{ml}$ Tween 20

Blocking buffer:

$5 \%$ non-fat powder milk in TBS-Tween 20

For immunocytochemistry

PFA 4\% (for $1 \mathrm{~L})$ :

80g PFA in $0.1 \mathrm{mM}$ PB

PB (phosphate buffer for $2 \mathrm{~L}$ ):

Buffer 1: $0.2 \mathrm{M} \mathrm{NaH}_{2} \mathrm{PO}_{4}$ ( $\left(27,6 \mathrm{~g} \mathrm{NaH} 2 \mathrm{PO} 4 \mathrm{xH}_{2} \mathrm{O}\right.$ )

Buffer 2: $0.2 \mathrm{M} \mathrm{Na}_{2} \mathrm{HPO}_{4}\left(71.7 \mathrm{~g} \mathrm{Na}_{2} \mathrm{HPO}_{4 \mathrm{x}} 12 \mathrm{H}_{2} \mathrm{O}\right.$ )

PBS (for $1 \mathrm{~L}$ ):

$10 \mathrm{mM} \mathrm{PB}, 150 \mathrm{mM} \mathrm{NaCl}, 2,7 \mathrm{mM} \mathrm{KCl}$,

(50 ml PB, 8,77 g NaCl, 200 mg KCl, $900 \mathrm{ml} \mathrm{H}_{2} \mathrm{O}$ )

\subsubsection{Antibodies}

\subsubsection{Primary antibodies}

\begin{tabular}{lll}
\hline Antibodies & Raised in & Provenience \\
\hline Anti-Actin & rabbit & S i g m a - A I d r i c h , \\
& Germany \\
Anti-Complexin 2 & rabbit & Prof. Dr. M. Missler \\
Anti-Dynamin & rabbit & Prof. Dr. M. Missler
\end{tabular}




\begin{tabular}{|c|c|c|}
\hline Anti-GABAR 1 & goat & Santa Cruz, USA \\
\hline Anti-GABAR 2 & rabbit & Abcam, UK \\
\hline Anti-GABAR 3 & rabbit & Abcam, UK \\
\hline Anti-GABAR 4 & rabbit & Abcam, UK \\
\hline Anti-GABAR ${ }_{\beta} 3$ & goat & Santa Cruz, USA \\
\hline Anti-Gephyrin & mouse & $\begin{array}{l}\text { Synaptic Systems, } \\
\text { Germany }\end{array}$ \\
\hline Anti-GluR 1 & rabbit & Chemicon, USA \\
\hline Anti-GluR 2/3 & rabbit & Chemicon, USA \\
\hline Anti-Gephyrin & mouse & $\begin{array}{l}\text { Synaptic Systems, } \\
\text { Germany }\end{array}$ \\
\hline Anti-GlyR & mouse & Alexis, UK \\
\hline Anti-HSP70 & goat & Santa Cruz, USA \\
\hline Anti-Mint1 & rabbit & Prof. Dr. M. Missler \\
\hline Anti-Munc18 & mouse & Prof. Dr. M. Missler \\
\hline Anti-NMDAR1(54.1) & mouse & Upstate, USA \\
\hline Anti-NMDAR1(54.2) & mouse & $\begin{array}{l}\text { Synaptic Systems, } \\
\text { Germany }\end{array}$ \\
\hline Anti-NMDAR2A & rabbit & Chemicon, USA \\
\hline Anti-NMDAR2B & rabbit & Chemicon, USA \\
\hline Anti-PSD-95 & mouse & Abcam, UK \\
\hline Anti-Rab3A & mouse & Prof. Dr. M. Missler \\
\hline Anti-SNAP-25 & mouse & $\begin{array}{l}\text { Synaptic Systems, } \\
\text { Germany }\end{array}$ \\
\hline Anti-Syntaxin1 & mouse & Prof. Dr. M. Missler \\
\hline Anti-Synaptotagmin 1 & rabbit & Prof. Dr. M. Missler \\
\hline Anti-Synaptophysin & mouse & Dako, Denmark \\
\hline Anti-Synaptobrevin & mouse & Prof. Dr. M. Missler \\
\hline Anti-Synapsin1\&2 & rabbit & Prof. Dr. M. Missler \\
\hline Anti-VIAAT & rabbit & Chemicon, USA \\
\hline Anti-VGLUT 1 & rabbit & Chemicon, USA \\
\hline
\end{tabular}


Materials and methods

\begin{tabular}{cccc} 
Anti-VGLUT 2 & rabbit & \multicolumn{2}{c}{ Chemicon, USA } \\
\hline $\begin{array}{c}\text { 2.2.3.2 Secondary antibodies } \\
\text { Secondary antibody } \\
\text { specificity }\end{array}$ & Host & Conjugates & Provenience \\
\hline Anti-mouse lgG & Goat & HRP & Chemicon, USA \\
Anti-goat lgG $(\mathrm{H}+\mathrm{L})$ & Donkey & HRP & Dianova, USA \\
Anti-rabbit lgG & Donkey & HRP & Amersham \\
& & & Biosciences, UK \\
Rabbit Cy5 IgG $(\mathrm{H}+\mathrm{L})$ & Goat & Cy5 & Dianova, USA \\
\hline
\end{tabular}




\subsection{Methods}

\subsubsection{Animals}

All animal experiments were carried out in accordance with the guidelines of the Ethics committee of the University of Göttingen.

\subsubsection{MeCP2 -/y mice}

We used the strain [B6.129P2(C)-Mecp2 tm1-1Bird] as a mouse model for Rett syndrome (17). The mice were obtained commercially from The Jackson Laboratory (Bar Harbor, ME) and maintained on a C57BL/6J background. Hemizygous mutant Mecp2 males were generated by crossing heterozygous knockout females with C57BL/6J wild-type males. All experiments were performed on hemizygous (/y) MeCP2 males and their sex- and age-matched littermate controls (+/y). We used (-/y) MeCP2 males because heterozygous (+/-) MeCP2 female mice have a heterogeneous phenotype as a result of the X-inactivation profile of the $X$ linked MeCP2 gene. Genotyping was performed as described before (Stettner et al. 2007), essentially following The Jackson Laboratory protocols (forward primer CreF, 5'-GACCGTACACCAAAATTTGCCTG-3'; reverse primer CreR, 5' $\square-$ TTACGTATATCCTGGCAGCGATC-3'). Many thanks to Anna-Maria Bischoff from the University of Göttingen for taking care of the breeding, handling, and genotyping of the mice.

\subsubsection{NL1 KO mice}

NL-1 KO mice were generated as previously described (Varoqueaux et. al., 2006). To generate mice that lacking NL-1, the exon sequence covering the translational start site and at least $380 \mathrm{bp}$ of $5^{\prime}$ coding sequence of the gene were deleted by homologous recombination in embryonic stem cells. The mice were generated and generously supplied by the lab of Prof. N. Brose. Many thanks to Ute Bormann for breeding and handling the mice and to Frederique Varoqueaux for taking care of all the organizational problems.

\subsubsection{Nbea KO mice}

Nbea KO mice were generated from the gene-trap ES cell line RRK418 obtained from BayGenomics, a member of the International Gene Trap Consortium. This Sv129-derived cell line has integrated the gene-trap vector pGT21xf in intron 6 of the Nbea gene. Genomic DNA from RRK418 around the integration site was amplified by PCR and sequenced. The vector was found to have inserted $385 \mathrm{bp}$ downstream of exon 6 . The first $389 \mathrm{bp}$ of the gene-trap vector had been lost in the course of 
insertion, but the sequence loss was upstream of the vector's splice acceptor site and did not affect the function of the vector (Fig. 1). ES cells were injected into C57BI/6N blastocysts and implanted into foster mothers at the Uppsala University Transgenic Facility (UUTF). Chimeric male offspring were mated with C57BI/6N females and agouti pups were genotyped by PCR of genomic DNA. The line was maintained by backcrossing of heterozygous transgenic animals with C57BI/6N mates. For PCR genotyping, three primers were employed in a single amplification reaction: a single forward primer for both the wt and the transgenic allele in exon 6 (Ex6F, 5'-TTTCGTACTAGCAAAGGAGTG-3') and specific reverse primers for the wt and transgenic alleles in intron 6 (Int6/7R, 5'-GACTAAAAGATGGCAGCTCTC3') and in the gene-trap insert (Trap5'R, 5'-TTTGAGCACCAGAGGACATC-3'), respectively (see Fig. 1A). Because of the length of the gene-trap insert (8.3 kb), the wt reverse primer produces an amplification product only from the unmodified allele. The mice were generated by Prof. Dr. Manfred W. Killiman from University of Uppsala and breed by Prof. Dr. Markus Missler from the University of Göttingen (currently Head of the Anatomy Institute at the University of Münster). Many thanks to Sandra Gerke from University of Göttingen and Kai Kerkhoff from University of Münster for breeding, handling, and genotyping of the mice.

\subsubsection{Ventilation recordings}

Ventilation patterns were recorded by whole-body pletysmography, for which unanaesthetized P1 (for NL1 mice) or P7 (for MeCP2 mice) wild-type and their KO littermates were placed in a $50 \mathrm{ml}$ closed chamber connected to a differential pressure transducer (CD15 Carrier Demodulator, ValiDyne Engineering, Northridge, CA). The analog signal of ventilation-related changes of air pressure was amplified and digitized using an A/D-converter (DigiData 1322A, Molecular Devices, Sunnyvale, $\mathrm{CA}$ ), and analyzed using commercially available pClamp 9.2 software (Molecular Devices, Sunnyvale, CA).

\subsubsection{Electrophysiology}

\subsubsection{Brain slice preparation}

The preparation of transverse brainstem slices containing the rostroventrolateral medula (RVLM) and hypoglossal nucleus $(\mathrm{NH})$ followed the general procedure of making thin slices from the tissue of mouse central nervous system described in Zhang et al. (1999). Mice were decapitated at C3-C4 spinal level. The whole brain 
was carefully removed from the cut-open skull, immediately transferred into ice-cold artificial cerebrospinal fluid (ACSF), which was already bubbled with carbogen (95\% $\mathrm{O}_{2}$ and $5 \% \mathrm{CO}_{2}$ ). The brainstem was separated from the cerebellum and forebrain. Transverse $200 \mu \mathrm{m}$-thick slices were cut using a vibratome slicer (752M Vibroslice, Campden IInstruments, UK). Sectioning of the brainstem was done from the rostral to caudal part and fourth ventricle was used as a marker for the start of the region of the interest. After sectioning, each slice was quickly placed into an incubation chamber containing aerated ACSF. Slices were kept at $28-30{ }^{\circ} \mathrm{C}$

\subsubsection{Whole-cell patch-clamp}

All electrophysiological recordings were done on acute brainstem slices containing RVLM and $\mathrm{NH}$. The slices were placed into the glass bottomed recording chamber and fixed by platinum wire with a grid of parallel nylon threads, to avoid of slice dislocation. The slice was continuously perfused with aerated extracellular solution during experiments, using a pump (Watson Marlow, USA). The brain slices were visualised under an Axioscope 2 FSplus microscope (Zeiss, Germany) using a $5 x$ and a 40x water immersion objective, respectively. Patch pipettes were pulled from borosilicate glass micropipettes (GC 150-10F, Clark Electromedical Instruments, UK) using a multistage puller (P87, Sutter Instrument Co. Novato, USA). Resistance of the electrodes varied between 4 and $8 \mathrm{M} \Omega$. Recordings were performed using a WPC-100 amplifier (ESF, Göttingen). All experiments were performed in the voltageclamp configuration, using "whole-cell patch-clamp" technique. The first step in this method is formation of a gigaseal, by touching the cell surface with pipette and applying gentle suction. After application of a short pulse of negative pressure to the electrode the patch of membrane under the pipette is ruptured, reaching the wholecell configuration. After establishing of whole-cell configuration the recordings were performed at a holding potential of $-70 \mathrm{mV}$.

The membrane currents were filtered by a four-pole Bessel filter set at a corner frequency of $1 \mathrm{kHz}$ and digitized at a sampling rate of $5 \mathrm{kHz}$ using the DigiData 1322 interface (Molecular Devices, USA). All experiments were conducted at $32{ }^{\circ} \mathrm{C}$.

\subsubsection{Spontaneous and miniature PSCs recordings}

For spontaneous and miniature experiments, patch electrodes were filled with INK solution (see 2.1.2.2). As the concentration of chloride-ions was similar between intra- and extracellular solutions, the reversal potential of chloride was close to $0 \mathrm{mV}$. Spontaneous GABA- and glycinergic IPSCs were recorded at a $\mathrm{Cl}^{-}$reversal potential of about $0 \mathrm{mV}$ in $10 \mu \mathrm{M} C N Q X$ and $40 \mu \mathrm{M}$ AP5. Miniature GABA- and glycinergic PSCs (mIPSCs) were recorded with the same drugs, but in presence of $0.5 \mu \mathrm{M}$ 
tetrodotoxin (TTX) to block action potentials. Spontaneous glutamatergic EPSCs were recorded in the presence of $1 \mu \mathrm{M}$ strychnine and $1 \mu \mathrm{M}$ bicuculine. Miniature glutamatergic EPSCs (mEPSCs) were recorded in presence of the same drugs, again with extra $0.5 \mu \mathrm{M}$ tetrodotoxin (TTX). In control and after drug applications, spontaneous and minis were recorded in presence for 3 minutes, Signals with amplitudes of at least 2 times above the background noise were selected.

\subsubsection{Evoked PSCs recordings}

For experiments of evoked EPSCs, patch electrodes were filled with INK solution (see 2.1.2.2). Evoked glutamatergic and GABAergic/glycinergic PSCs were recorded from hypoglossal neurons in the presence of $1 \mu \mathrm{M}$ strychnine and $1 \mu \mathrm{M}$ bicuculline or $10 \mu \mathrm{M} C N Q X$ and $40 \mu \mathrm{M} \mathrm{AP5}$, respectively. PSCs were evoked by stimulations of axons of interneurons close to the RVLM using a bipolar platinum electrode. A pulse stimulator (A-M systems Inc., USA) was used to apply currents of different stimulation strengths. Peak amplitudes were averaged from 25 consecutive responses. To monitor changes in input resistance, current responses to a $-10 \mathrm{mV}$ voltage step $(20 \mathrm{msec})$ from a holding potential of $-70 \mathrm{mV}$ were recorded before every fifth stimulus. In all experiments the distance between the stimulation and recording electrodes was similar between slices of different genotypes.

\subsubsection{Drug application experiments}

For drug application ("puff") experiments patch electrodes were filled with INK solution (see 2.1.2.2). Drug was directly applied in close proximity to neurons by glass pipettes filled with muscimol, glycine, NMDA or AMPA (all $5 \mathrm{mM}$ ) dissolved in above bath solution. For minimizing the variation between experiments, we kept tip size of pipette, pressure $(0.5 \mathrm{mbar})$ and time $(500 \mathrm{~ms})$ constant for all experiments. In addition, the distance between pipette tips and the cell were monitored using a LCD camera, and was also kept constant between different experiments. The remaining variation between experiments was random in nature, and was not specifically related to the genotype of the tested animals, especially because the experimenter was unaware of the genotype.

\subsubsection{Sucrose experiments}

In order to elicit a hypertonic response (Rosenmund and Stevens 1996), sucrose (300 mM) was applied in the perfusion flow for 2 seconds. The patch electrodes were filled with INK solution (see 2.1.2.2). 
2.3.3.7 Voltage-gated channels recordings

Voltage-activated currents were measured from neurons of the RVLM with patch electrodes containing INLOW intracellular solution. After establishing the wholecell configuration, membrane capacitance serial and membrane resistances were estimated from current transient induced by $20 \mathrm{mV}$ hyperpolarization voltage commands from a holding potential of $-70 \mathrm{mV}$. The serial resistance was compensated by $80 \%$. For correction of current measurements P/4 protocol was used. According to this protocol four leak-subtraction pulses were applied immediately before the main command step and leak currents were subtracted.

\subsubsection{Kinetic analysis}

mPSCs decay was fitted by double exponential equations of the form $I(t)=A_{\text {fast }}$ $\exp \left(-\mathrm{t} / \tau_{\text {fast }}\right)+A_{\text {slow }} \exp \left(-t / \tau_{\text {slow }}\right)$, where I ( $\left.t\right)$ was the amplitude of mPSCs at time $t$, $\mathrm{A}_{\text {fast }}$ and $\mathrm{A}_{\text {slow }}$ were the amplitudes of the fast and slow decay components, and $\tau_{\text {fast }}$ and $\tau_{\text {slow }}$ were their respective decay time constants (Jonas et al. 1998; Nabekura et al. 2004).To allow for easier comparison of decay times between experimental conditions, the two decay time components were combined into a weighted mean decay time constant $\tau_{w}=\left[I_{f} /\left(I_{f}+I_{s}\right)\right] \tau_{f}+\left[I_{s} /\left(I_{f}+I_{s}\right)\right] \tau_{s}$.

In some experiments (see Fig. 3.3) mIPSCs were considered to have a monoexponential decay when the relative contribution of one of the exponential distributions was $<1 \%$. Thus, the decision about whether a single mIPSC decayed with a single or dual component was completely objective. mGPSC decay was fitted to a monoexponential function.

\subsubsection{Data analysis}

All data are expressed as mean \pm standard error of the mean. $P$-values represent the results of two-tailed unpaired Student's $t$ tests, with or without Welch's correction, depending on the distribution of the data (tested with a Kolmogorov-Smirnov test). Data acquisition and analysis was done using commercially available software: pClamp 9.0 (Molecular Devices, Sunnyvale, CA), MiniAnalysis (SynaptoSoft, Decatur, GA) and Prism 4 (GraphPad Software, San Diego, CA).

\subsubsection{Biochemical procedures}

\subsubsection{Protein extracts preparation}

Brains from littermate wild-type and KO mice were quickly removed from the cutopen skull, btrainstem was cut and immediately frozen by immersion in liquid 
Materials and methods

nitrogen and stored at $-80^{\circ} \mathrm{C}$. The tissues of selected genotypes were homogenized in omogenization buffer with a glass Teflon homogenisator (homgen ${ }^{\text {plus }}$, Schütt) at setting $1200 \mathrm{rpm}$. Afterwards the homogenate was aliquoted ant stored at $-20^{\circ} \mathrm{C}$. The protein concentration was measured with the Lowry assay (see in section 2.3.1). For using the protein sample was resuspended in $3 x$ loading buffer and boiled at $100^{\circ} \mathrm{C}$ for $5 \mathrm{~min}$. The boiling denatures the proteins, unfolding them completely.

\subsubsection{Protein concentration estimation}

The total protein concentration was determined according to Lowry assay, using the total protein kit from Sigma with bovine albumin serum (Sigma-Aldrich, St.Louis $\mathrm{MO})$ as a standard. At first a BSA standard curve with sample of known protein

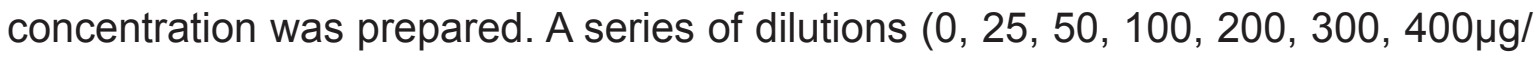
$\mathrm{ml}$ ) were made in replicates of three with a final volume of $50 \mu \mathrm{l}$.

Protein samples $(1-3 \mu \mathrm{l})$ were diluted in SDS to $50 \mu \mathrm{l}$. Each protein concentration measurement was performed in triplicate. The following step was the transferring of standards and samples into microplate (96 well plate; Sarsdedt Newton Inc., Newton USA). The Lowry reagent $(50 \mu \mathrm{l})$ was added to each well and incubated for 20 min at RT, which was followed by addition of $25 \mu$ l of Folin-Ciocaltau's phenol reagent. The addition this reagent leads finally to an intensive blue staining, which was measured by absorbance at e wavelength between 500 and $800 \mathrm{~nm}$. All absorbance estimations were done using a Microplate reader (BioRad). Samples without protein were served as reference. Analyses and statistics of the standard curve were performed using Sigma plot software.

\subsubsection{SDS-PAGE}

SDS-PAGE is a common biochemical method for protein separation. According to this method, proteins can be separated based on their molecular weight, as they move through polyacrilamide gel in response to an electric field. Protein samples before being subjected to electrophoresis are mixed with buffer containing SDS and ß-mercaptoethanol. SDS mediates the disruption of three-dimensional structure of proteins by breaking non-covalent bonds and the loading of proteins with negative charges. ß-mercaptoethanol breaks disulfide bonds. Protein gel electrophoresis was performed using a minigel vertical apparatus. Glass-plate sandwich was built for preparation of the gel. The glass walls $(10.5 \times 10)$ were cleaned, sealed with silicone rubber band and clamped. After assembling the glass-plate sandwich of the electrophoresis apparatus, the stacking and separating gel solutions were prepared. 
Materials and methods

\begin{tabular}{lll}
\hline \hline Solution & Separation gel (10\%) & Stacking gel (5\%) \\
\hline AA30 & $2.5 \mathrm{ml}$ & $0.325 \mathrm{ml}$ \\
\hline Tris buffer pH 8.8 & $1.875 \mathrm{ml}$ & \\
\hline Tris buffer $\mathrm{pH} 6.8$ & & $0.787 \mathrm{ml}$ \\
\hline $\mathrm{dH}_{2} 0$ & $3.125 \mathrm{ml}$ & $1.525 \mathrm{ml}$ \\
\hline Themed & $7.5 \mu \mathrm{l}$ & $3.7 \mu \mathrm{l}$ \\
\hline APS & $40 \mu \mathrm{l}$ & $20 \mu \mathrm{l}$ \\
\hline
\end{tabular}

The separation gel was poured first and the surface was covered with isopropanol, which straightens the surface of the gel. After the gel polymerized (in 30-40 min), isopropanol was removed. The stacking gel was then pored over the separation gel, and the comb of $0.6 \mathrm{~mm}$ thickness was inserted. When the stacking gel was polymerized (in 15-20 min), the comb and silicone rubber band were removed, and the gel was then placed into the gel electrophoresis apparatus and filled with running buffer. Shortly before loading the samples were boiled. The molecular weight marker (for estimating the molecular weight of unknown proteins) and samples were loaded into the wells of stacking gel using a Hamilton Syringe (Hamilton Company; Reno, Nevada, USA). The gel electrophoresis was carried out at 80 Volt until the samples got stacked at the lower border of the stacking gel, and then at 150 Volt for 1-2 Hours.

\subsubsection{Western blotting}

The protein samples separated from SDS-PAGE can be transferred onto nitrocellulose membranes (Hybond ECL, Amersham), on the surface of which they are accessible to detection with specific poly- or monoclonal antibodies. Transfer of proteins from the gel onto nitrocellulose membrane was done using semi-dry blotting method. The transfer nitrocellulose membrane and 6 sheets of Whatman filter papers of the same size as a gel were soaked with the transfer buffer for $15 \mathrm{~min}$. The transfer stack was assembled from the anode to the cathode in the following order: 3 sheets of Whatman filter paper, transfer membrane, gel and 3 sheets of Whatman filter paper and during this procedure bubbles were removed. For protein transfer a constant current of $150 \mathrm{~mA}$ was applied overnight. Afterwards the blotted membrane was removed and stained with removable Ponceau-S stain for 2 min at RT in order to test the efficiency of protein transfer. It was then distained by washing for a few minutes in TBS-Tween. 


\subsubsection{Immunodetection}

The membrane was first incubated in blocking solution for 1 hour at RT in order to inhibit non-specific binding sites of antibodies to proteins. Afterwards the membrane was incubated with the primary antibody in appropriate dilution in the blocking solution overnight at $4^{\circ} \mathrm{C}$. After three washing steps for 10 min each with TBS-Tween, the membrane was incubated with HRP-conjugated antibody solution for 1 hour at RT, which binds to the heavy chain of primary antibody, followed by extensive washing steps. HRP coupled to the secondary antibody reduces the hydrogen peroxide and the resulting oxygen oxidizes the luminal, which releases the light. To visualize antigen-antibody reaction enzymatic chemiluminescence's detection reagents were used (AceGlow reagents; psqLab biotechnoligie $\mathrm{GmbH}$ ). The detection reagents were mixed according to manufacturer's protocol. Briefly the mixture of Solution A and $B(1: 1)$ was poured over the membrane for $1 \mathrm{~min}$ at RT. The membrane was placed into dark chamber and a CCD camera detected the emitted light.

\subsubsection{Immunocytochemistry}

\subsubsection{Brain tissue preparation}

Mice were deeply anaesthetized with TBE (tribromoethanol) until they were unresponsive to painful stimuli. A thoracotomy was perormed and animals were perfused through the aorta with $0.9 \%$ sodium chloride followed by $100 \mathrm{ml} 2 \%$ paraformaldehyde in $0.1 \mathrm{M}$ phosphate buffer. The whole brain was removed, postfixed for 1 hour in the same fixative at $4{ }^{\circ} \mathrm{C}$. The tissue was cryoprotected in 10-30 \% sucrose overnight at $4{ }^{\circ} \mathrm{C}$. Afterwards it was frozen by tissue freezing medium on dry ice and stored at $-80^{\circ} \mathrm{C}$. Series of transverse sections of brainstem with a thickness of $12 \mu \mathrm{m}$ were cut using a cryoslicer. Each section was quickly placed on the slide. After sectioning the slides were kept at $-80^{\circ} \mathrm{C}$.

\subsubsection{Immunofluorescence staining}

Before starting the immunostaining, the slices were washed three times with PBS. The blocking of non-specific binding sites and permeabilisiation of slices were done using $2 \%$ NGS and $0.2-0.3 \%$ Triton X-100 in phosphate-saline buffer (PBS) for 20-30 min at RT. Sections were incubated overnight at $4^{\circ} \mathrm{C}$ in primary antibodies dissolved in PBS containing $2 \%$ NGS and 0.2-0.3 \% Triton X-100. After incubation with primary antibodies the sections were washed 3 times for each 10 min and then incubated for 1 Hour at RT in the dark with species-specific flurochromeconjugated secondary antibodies, followed by three washing steps for 10 min each. 
Finally, sections were slightly air-dried and coverslipped with fluorescent mounting medium.

\subsubsection{Data analysis}

Sections from immunofluorescence staining were visualized by confocal laser scanning microscopy (Zeiss LSM 510 META). The region for quantifications were chosen using same criteria as for electrophysiology The region of the ventrolateral medulla was recognized based on the appearance of nucleus ambiguus and inferior olive (Fig. 2.1). The region of the hypoglossal nucleus was easily identified based on the appearance of the nucleus (Fig. 2.1). Images (1024x1024 pixel) were recorded at a zoom factor of 5 , using a $40 x$ oil-immersion objective. For quantitative analyses, the gain and offset were held constant across all images, which give a possibility for intensity comparisons. For quantification, one image per mouse was chosen and VIAAT or VGLUT puncta were manually counted with the experimenter being blind respective to the genotype. Data analysis was done using commercially available software (Prism 4 Software, Graph Pad). 
Results

\section{Results}

\subsection{MeCP2 KO mice}

\subsubsection{Excitatory-inhibitory imbalance appears early in the brainstem respiratory network of MeCP2 KO mice}

Rett syndrome patients experience ventilation problems that may cause lethal apnea (Hanefeld et al. 1986; Kerr and Burford 2001) and the onset of these problems appears early in childhood (REF). Since MeCP2-deficient mice also show respiratory problems (Stettner et al. 2007; Viemari et al. 2005) but at an adult age we were interested in possible cellular defects leading to them before the onset of the symptoms. At postnatal day 7 (P7), no major difference could be observed in
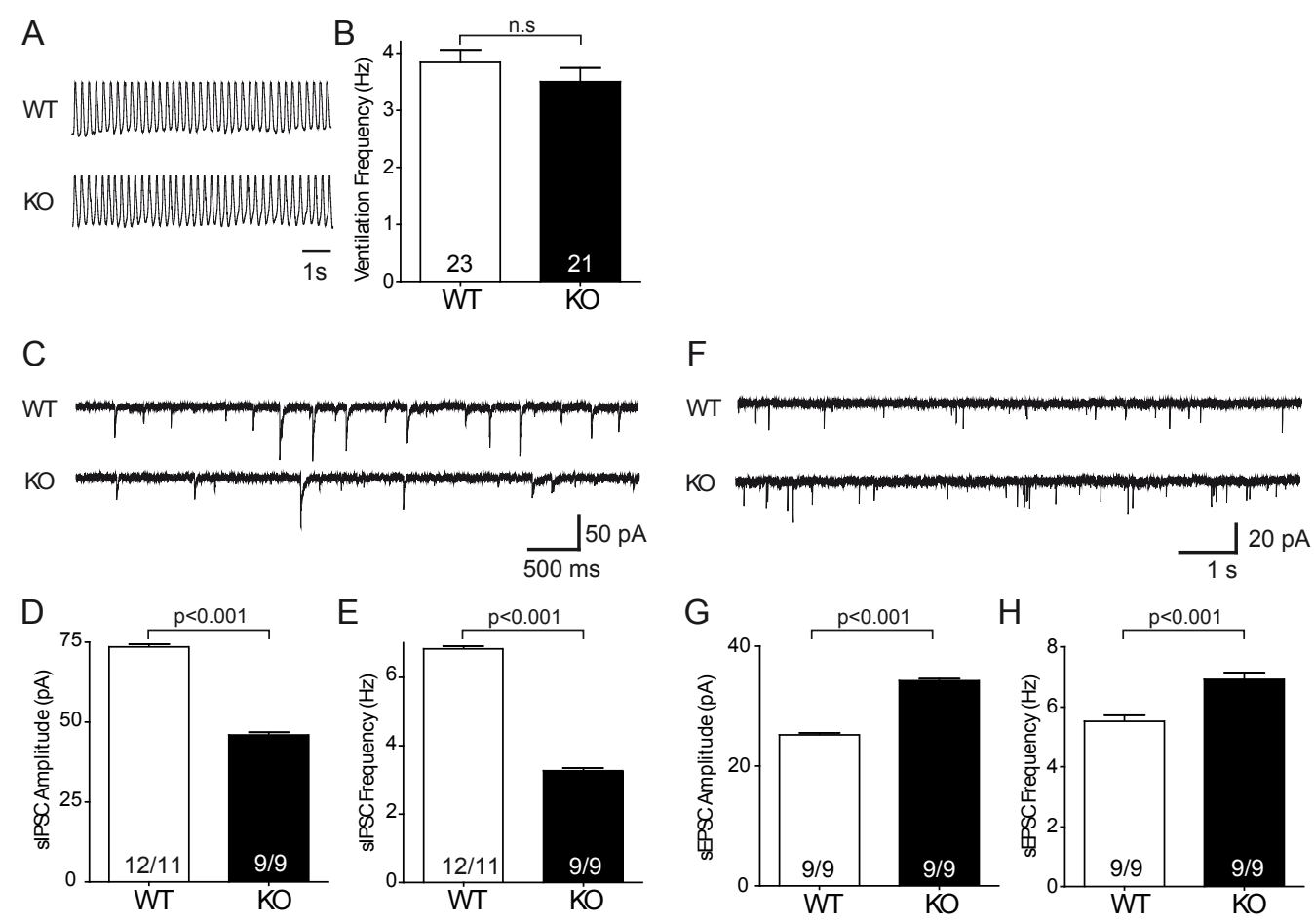

Figure 3.1 Excitatory-inhibitory imbalance in the ventrolateral medulla of MeCP2 KO mice. $(A$ and $B$ ) Representative ventilation traces $(A)$ and averaged ventilation frequencies $(B)$ of MeCP2 mutant mice (KO) and their littermate controls (WT), measured by whole-body pletysmography at postnatal day P7. (C) Representative recordings of spontaneous, pharmacologically isolated (50 $\mu \mathrm{M}$ CNQX and $20 \mu \mathrm{M}$ APV) inhibitory postsynaptic currents (sIPSC) from neurons in the ventrolateral medulla at P7. (D and E) Averaged amplitude (D) and frequency (E) of sIPSC in KO and WT neurons. (F) Representative recordings of spontaneous, pharmacologically isolated ( $1 \mu \mathrm{M}$ strychnine and 1 $\mu \mathrm{M}$ biccuculine) excitatory postsynaptic currents (sEPSC) from neurons in the hypoglossus nucleus at P7. ( $G$ and H) Averaged amplitude (D) and frequency (E) of sEPSC in KO and WT neurons. Data shown represent mean \pm SEM. Numbers within the bar graphs indicate the number of neurons/mice tested for each genotype. 


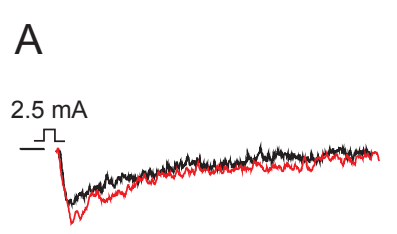

D

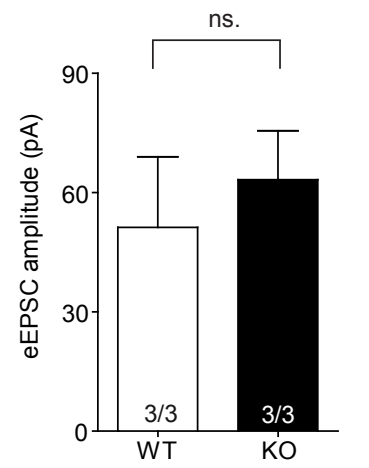

G
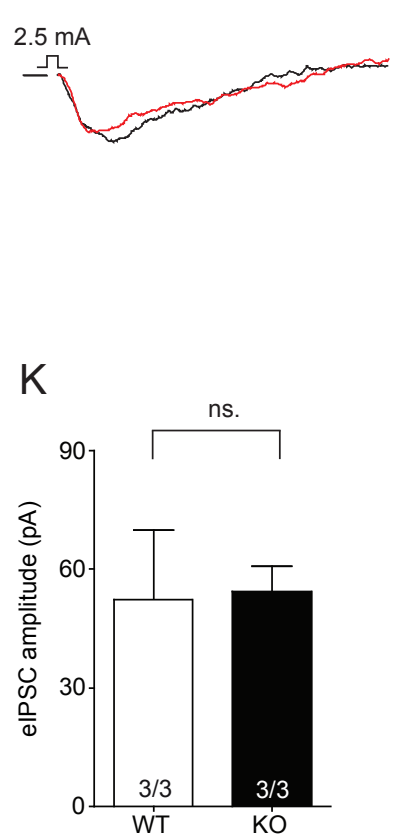

B

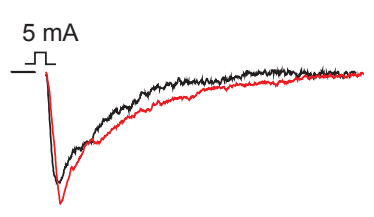

E

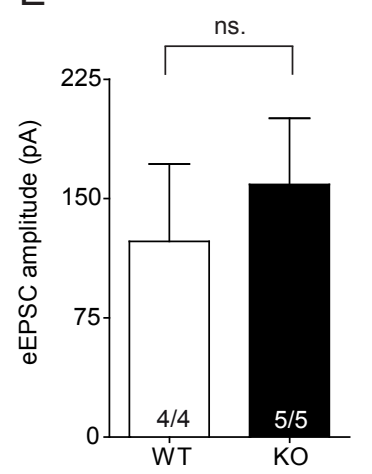

$\mathrm{H}$

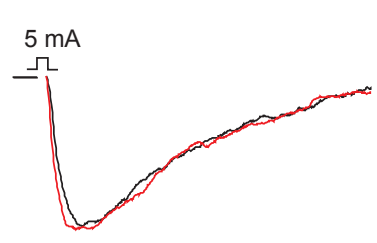

$\mathrm{L}$

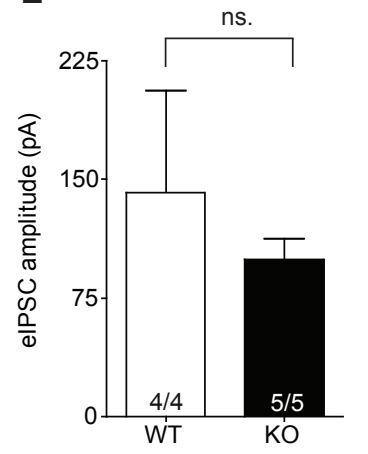

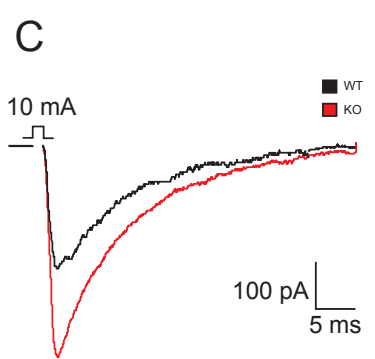

F

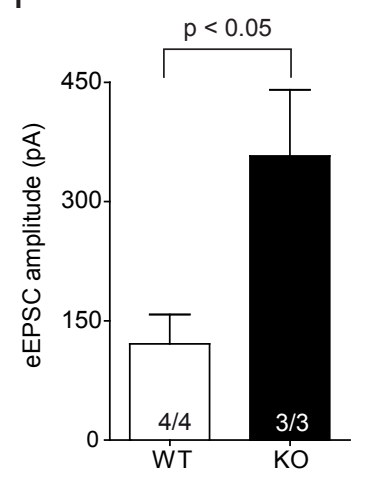

I

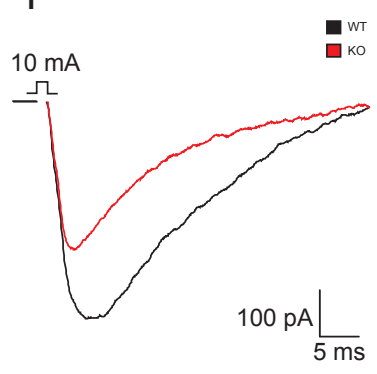

M

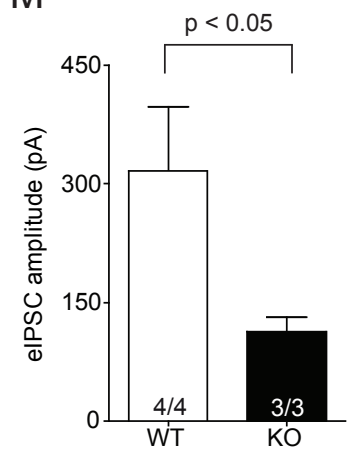

Figure 3.2 Excitatory-inhibitory imbalance in the hypoglossal nucleus of MeCP2 KO mice. (AF) Evoked excitatory eEPSCs. Sample traces (A, B, C) and their correspondent averaged amplitude (D, E, F) of pharmacologically isolated eEPSCs in NH neurons from WT (black) and KO (grey) mice, at different stimulation intensities. (G-M) Evoked inhibitory elPSCs. Sample traces (G, H, I) and their correspondent averaged amplitude (K, L, M) of pharmacologically isolated elPSCs in NH neurons from WT (black) and KO (grey) mice, at different stimulation intensities. Data shown represent mean \pm SEM. Numbers within the bar graphs indicate the number of neurons/mice tested for each genotype. 
ventilation activity between the hemizygous MeCP2 males (KO) compared to their sex- and age-matched littermate controls (WT) (Fig. 3.1A and B). However, patchclamp recordings of the overall activity in acute brainstem slices revealed a markedly depressed amplitude (WT: $73.5 \pm 0.9 \mathrm{pA}, \mathrm{KO}: 46 \pm 0.8 \mathrm{pA} ; \mathrm{p}<0.001)$ and frequency (WT: $6.8 \pm 0.1 \mathrm{~Hz}, \mathrm{KO}: 3.3 \pm 0.1 \mathrm{~Hz} ; \mathrm{p}<0.001$ ) of spontaneous inhibitory synaptic currents (sIPSCs) in MeCP2-deficient mice at P7 (Fig. 3.1C-E). In contrast, both the amplitude (WT: $25.2 \pm 0.3 \mathrm{pA}, \mathrm{KO}: 34.3 \pm 0.3 \mathrm{pA} ; \mathrm{p}<0.001$ ) and frequency (WT: $5.5 \pm 0.2 \mathrm{~Hz}, \mathrm{KO}: 6.9 \pm 0.3 \mathrm{~Hz} ; \mathrm{p}<0.001$ ) of spontaneous excitatory activity (sEPSCs) were slightly increased in MeCP2 KO mice compared to their littermate controls of the same age (Fig. 3.1F-H).

To verify if the inhibition/excitation imbalance showed above is characteristic to the entire network and not restricted to RVLM neurons we examined electrically evoked synaptic transmission in the $\mathrm{NH}$. Neurons from $\mathrm{NH}$ receive mixed inhibitory and excitatory inputs from the ipsilateral RVLM neurons (Li et. al, 2003). We placed a bipolar stimulation electrode on the dorso-medial of the nucleus ambiguous (Missler et. al, 2003; Varoqueaux et. al, 2006) on the axons that leave RVLM neurons and make synapse with $\mathrm{NH}$ neurons ( $\mathrm{Li}$ et. al, 2003). When we used lower stimulation intensities the evoked excitatory PSCs (eEPSC) amplitudes were unchanged between slices from $\mathrm{KO}$ mice as compared with slice from their WT littermates (at 2.5 $\mathrm{mA} 51.2 \pm 17.8 \mathrm{pA}$ in $\mathrm{WT}$ and $63.2 \pm 12.3 \mathrm{pA}$ in KO, Fig. 3.2 A, D; at $5 \mathrm{~mA} 123.1 \pm 48.7$ pA in WT and 158.8 $\pm 41.6 \mathrm{pA}$ in KO, Fig. 3.2 B, E). At a stimulation intensity of 10 $\mathrm{mA}$ the amplitude of evoked EPSC response was significantly higher in slices from KO mice (121 $\pm 36.9 \mathrm{pA}$ in $\mathrm{WT}$ and $357.3 \pm 83.2 \mathrm{pA}$ in $\mathrm{KO}, \mathrm{p}<0.05$, Fig. 3.2 C, F). Using the same intensity stimulations we analyzed next evoked inhibitory PSCs (elPSC) in the same nucleus. At stimulation intensities of 2.5 and $5 \mathrm{~mA}$, there was no significant difference in the amplitude of evoked IPSC between genotypes (at 2.5 $\mathrm{mA} 52.4 \pm 17.5 \mathrm{pA}$ in $\mathrm{WT}$ and $54.4 \pm 6.4$ in the KO, Fig. $3.2 \mathrm{G}, \mathrm{K}$; at $5 \mathrm{~mA} 142 \pm 99.5$ pA in WT and $64.3 \pm 12.9$ pA in KO, Fig. $3.2 \mathrm{H}, \mathrm{I}$ ). As opposite to the case of evoked EPSCs, when we increased the stimulation intensity to $10 \mathrm{~mA}$ the amplitude of the evoked EIPSC response was significantly reduced in KO slices (316 $\pm 80.9 \mathrm{pA}$ in WT and $113 \pm 18.6 \mathrm{pA}$ in $\mathrm{KO}, \mathrm{p}<0.05$, Fig. $3.2 \mathrm{I}, \mathrm{M}$ ), thus confirming in $\mathrm{NH}$ the excitatory/ inhibitory imbalance noticed in the spontaneous PSCs in RVLM (Fig. 3.1).

These results show a specific imbalance in the network activity of respiratory brainstem in the MeCP2-deficient mice, thereby confirming previous data from other brain regions but demonstrating for the first time that these cellular impairments are present already at such a very early stage of central nervous system development. 
Results

3.1.2 Miniature inhibitory synaptic transmission is depressed in the RVLM of MeCP2 KO mice

First, we analyzed in detail the impaired inhibitory (GABA- and glycinergic) synaptic transmission in the ventrolateral medulla that contains numerous inhibitory neurons (PBC, c.f. Richter and Spyer 2001). Since changes in spontaneous synaptic activity as shown above (Fig. 3.1) can be caused by pre- and/or postsynaptic defects, we next performed recordings of miniature postsynaptic currents (minis) in the presence of TTX to differentiate between the alternatives. The averaged frequency of inhibitory miniature postsynaptic currents (mIPSCs) was reduced by $>50 \%$ from $2.25 \pm 0.1 \mathrm{~Hz}$ in WT to $1.04 \pm 0.1 \mathrm{~Hz}$ in MeCP2 mutant mice ( $p<0.001$; Fig. $3.3 \mathrm{~A}, \mathrm{~B}$ ), whereas the overall amplitude did not differ significantly between the genotypes (Fig. $3.3 \mathrm{C}$ ). Since the kinetics of mIPSCs was different between WT and KO recordings we decided to further analyze this aspect.

\subsubsection{GABAergic, but not glycinergic synaptic transmission is depressed in the MeCP2 KO mice}

In the brainstem, part of the miniature IPSCs are dual-component events comprising glycine-and $\mathrm{GABA}_{A}$-receptor-mediated currents (Nabekura et al. 2004). To distinguish between the two components and to test if in the MeCP2 KO mice one component is preferentially affected over the other, we used an exponential fitting procedure to separate GABAergic and glycinergic miniature events based on their different decay times as described before (Jonas et al. 1998; Nabekura et al. 2004) (Fig. 3.3 D; see Methods for a detailed description). Using this paradigm, we observed no significant difference in the number of mixed and glycinergic miniature events between WT and MeCP2 KO neurons (Fig. 3.3 E). However, the miniature events that are mediated by GABA alone were reduced by $50 \%$ in mutant neurons (Fig. 3.3 E), suggesting

Table 3.1. Kinetics of GABAergic mini currents in WT and MeCP2 KO neurons

\begin{tabular}{ccccc}
\hline & $\begin{array}{c}\text { Rise time (10-90\%) } \\
(\mathbf{m s})\end{array}$ & $\begin{array}{c}\text { Decay time } \\
(\mathbf{m s})\end{array}$ & $\begin{array}{c}\text { Half-width } \\
(\mathbf{m s})\end{array}$ & $\begin{array}{c}\text { Area } \\
\left(\mathbf{p A} A^{*} \mathbf{m s}\right)\end{array}$ \\
\hline mGPSC & & & & \\
\hline Control & $2.6 \pm 0.4$ & $26.8 \pm 1.8$ & $14.5 \pm 1.3$ & $700.5 \pm 75.1$ \\
\hline KO & $1.8 \pm 0.3$ & $20.7 \pm 1.2^{*}$ & $11.9 \pm 0.8$ & $566.2 \pm 88.8$ \\
\hline
\end{tabular}



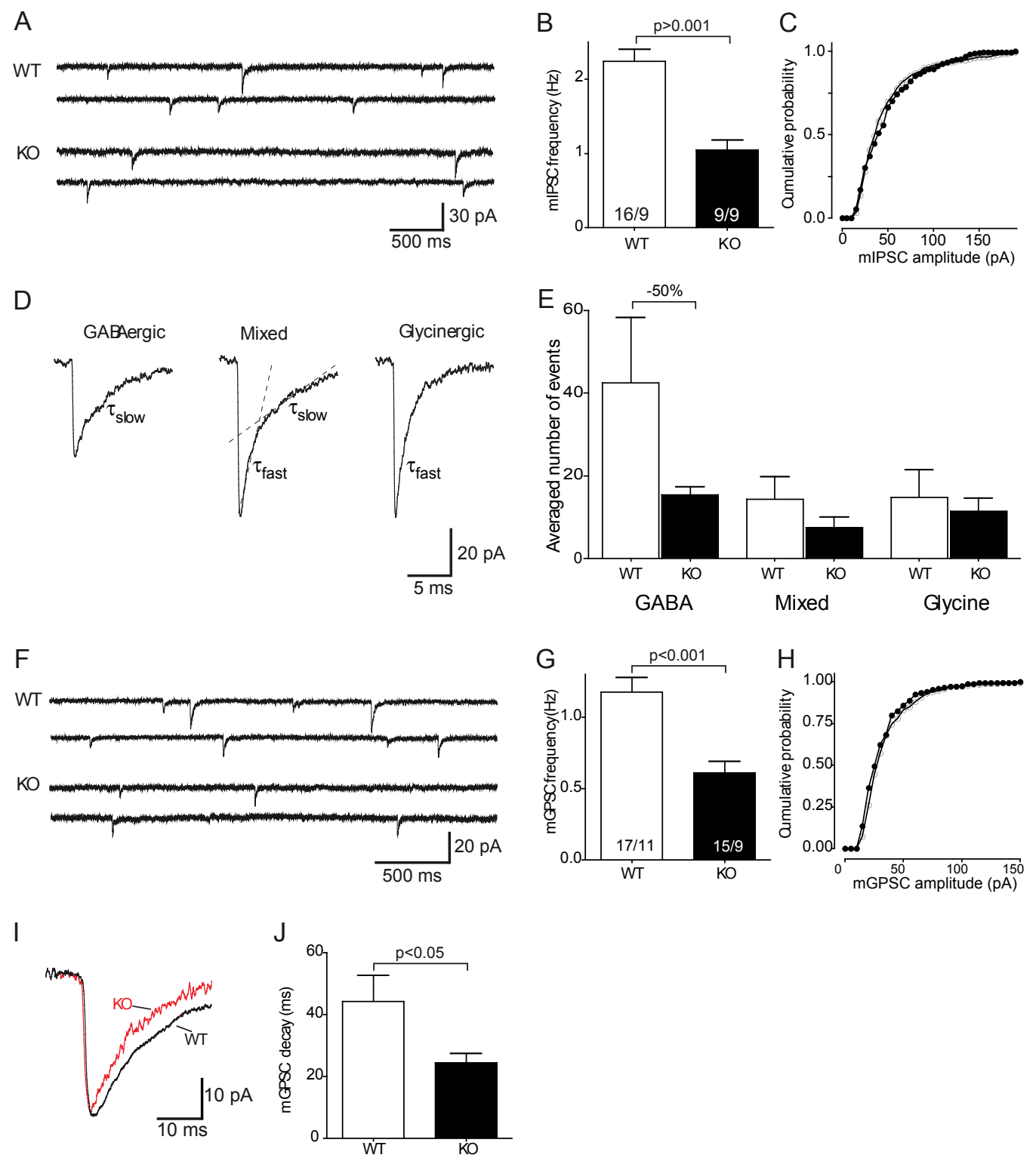

Figure 3.3 GABAergic but not glycinergic miniature postsynaptic currents are decreased in

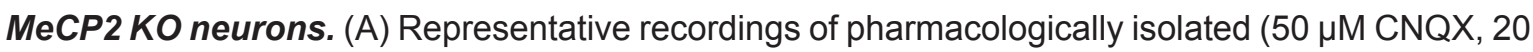
$\mu \mathrm{M} \mathrm{APV}$ and $0.5 \mu \mathrm{M} \mathrm{TTX)} \mathrm{miniature} \mathrm{postsynaptic} \mathrm{currents} \mathrm{(mIPSC)} \mathrm{in} \mathrm{neurons} \mathrm{from} \mathrm{the} \mathrm{ventrolateral}$ medulla at P7. (B and C) Averaged mean frequency (B) and cumulative amplitude (C) of mIPSCs in KO and WT neurons. (D) Prototypical averaged GABAergic, glycinergic and mixed mIPSC can be characterized by one (GABAergic with $\mathrm{t}_{\text {slow, }}$, glycinergic with $\mathrm{t}_{\text {fast }}$ ) or two (mixed) exponential functions, respectively. (E) Number of GABAergic, glycinergic and mixed events in WT and KO neurons. (F) Representative recordings of pharmacologically isolated (50 $\mu \mathrm{M}$ CNQX, $20 \mu \mathrm{M}$ APV, $0.5 \mu \mathrm{M}$ TTX and $1 \mu \mathrm{M}$ Strychnine) miniature GABAergic PSCs (mGPSC) in brainstem mutant and WT neurons. ( $G$ and $H$ ) Averaged frequency $(G)$ and cumulative amplitude $(H)$ of mGPSCs in mutant and WT neurons. (I) Representative mGPSCs currents (averaged from one trace each) from KO and WT mice. (J) Averaged decay time of mGPSCs in KO and WT mice, determined with a monoexponential fit as shown in panel (D). Data shown represent mean \pm SEM. Numbers within the bar graphs indicate the number of neurons/mice tested for each genotype. 
Results

that a specific reduction of GABAergic synaptic transmission is responsible for the reduced frequency of IPSCs in MeCP2 KO mice. To directly examine the GABAergic synaptic transmission, we pharmacologically isolated GABA-mediated miniature postsynaptic currents (mGPSCs) in the presence of $0.5 \mu \mathrm{M}$ TTX to block action potential-driven release and $1 \mu \mathrm{M}$ strychnine to suppress the glycinergic component (Fig. 3.3 F). Quantification demonstrated that the average frequency of mGPSC decreased from $1.17 \pm 0.1 \mathrm{~Hz}$ in WT to $0.6 \pm 0.1 \mathrm{~Hz}$ in MeCP2-mutant mice $(p<0.001$; Fig. $3.3 \mathrm{G}$ ), whereas no significant change in the amplitude of the GABAergic events was observed (Fig. 3.3 H). Consistent with the idea that GABA is responsible for the slower component of mIPSCs (Fig. 3.3D), analysis of sample traces (Fig. 3.3I) and quantification of the kinetics of mGPSCs (Table 3.1) revealed that the decay time was in fact faster in mutant neurons compared to littermate WT controls (WT: $44.3 \pm 8.5$ ms, KO: 24.4 \pm 3.1 ms; $p<0.05$; Fig. $3.3 \mathrm{~J}$ )

\subsubsection{Presynaptic components of GABAergic synapses are affected in the MeCP2 KO mice}

The reduction in frequency of miniature GABAergic synaptic events in the MeCP2 $\mathrm{KO}$ mice (Fig. 3.3) may suggest that presynaptic target molecules of the MeCP2dependent gene regulation exist at these synapses. To independently confirm the presynaptic impairment of GABAergic terminals and to test if molecules involved in the $\mathrm{Ca}^{2+}$ - independent steps of exocytosis are among the putative MeCP2 targets, we evoked charges of miniature GABAergic events (mGPSCs) by application of $300 \mu \mathrm{M}$ sucrose (Rosenmund and Stevens 1996). As evident from representative recordings (Fig. 3.4 A), the frequency of mGPSCs induced by the hyperosmolar solution was about three times higher in neurons of WT mice than of their MeCP2deficient littermates (Fig. 3.4 B). Since this difference reflects changes in the readily-releasable pool of synaptic vesicles, we performed immunofluorescence staining against the vesicular inhibitory transmitter transporter (VIAAT) essentially as described (Varoqueaux et al. 2006), using slices containing the ventrolateral medulla of MeCP2 KO mice and their WT littermate controls at P7 (Fig. 3.4 CD). Quantification revealed that the area density of VIAAT-positive punctae in the ventrolateral medulla was reduced in MeCP2 KO mice $\left(8.6 \pm 0.5\right.$ per $\left.100 \mu \mathrm{m}^{2}\right)$ as compared with WT controls ( $14.9 \pm 0.6$ per $100 \mu m^{2}$; Fig. $3.4 \mathrm{D}$ ), with no differences detectable in the background intensity between genotypes. Since GABA and glycine can be co-released from the same vesicles (Jonas et al. 1998; Wojcik et al. 2006) and glycinergic release was found largely intact (Fig. 3.3), these data indicate the density of GABAergic synaptic vesicles and/or terminals is specifically reduced in the ventrolateral medulla of MeCP2-deficient mice. 
Results

A

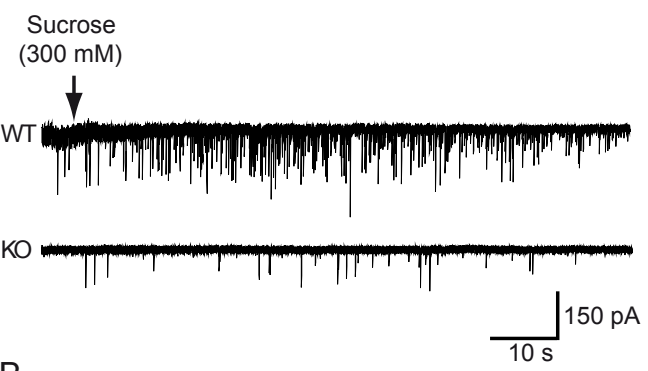

B

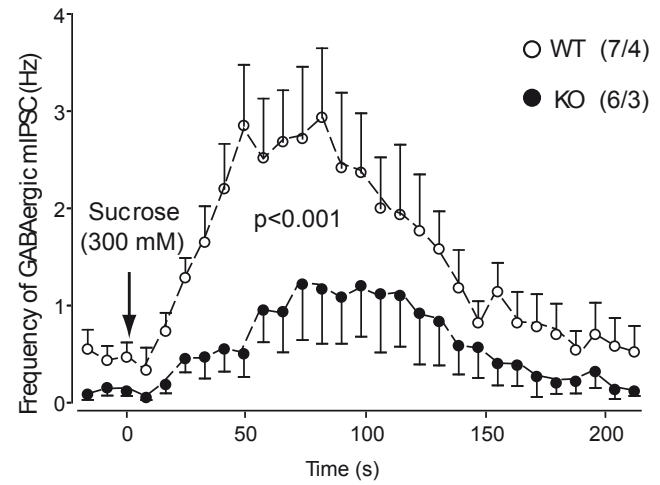

C

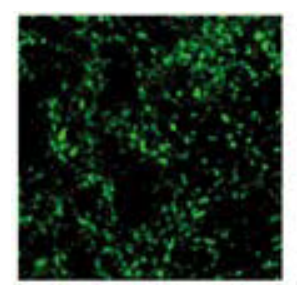

WT

D

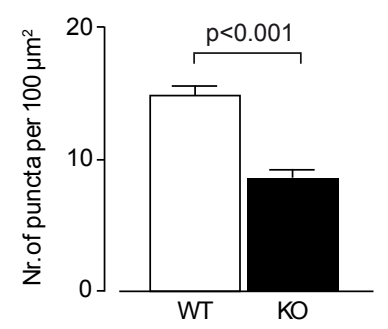

Figure 3.4 Decreased release from GABAergic terminals is caused by reduced density of inhibitory synapses in MeCP2 KO mice. (A) Representative traces of miniature GABAergic PSCs (mGPSC) in response to application of 300 $\mathrm{mM}$ sucrose (arrow) in WT and littermate KO mice. (B) Graph showing the time-frequency relationship of mGPSCs in response to the hyperosmolar sucrose stimulation. (C) Representative images of immunofluorescent stainings with anibodies against the vesicular GABA Transporter (VIAAT) in the ventrolateral medulla from $\mathrm{WT}$ and $\mathrm{KO}$ mice. (D) Quantification of VIAAT-positive puncta from three WT and KO mice (total number of punctae measured about 1500). Data shown represent mean \pm SEM. In panel $(B)$ the numbers in parentheses indicate the number of slices/mice tested for each genotype.

\subsubsection{Impaired function and subunit composition in postsynaptic GABA receptors of MeCP2 KO mice}

In addition to the presynaptic defect described above, our observation of reduced amplitudes of spontaneous inhibitory synaptic transmission in the ventrolateral medulla (Fig. 3.1) also raised the possibility of a postsynaptic defect, for example, in the expression of functional receptors. To analyze this aspect of the MeCP2 phenotype, we compared the responses of $\mathrm{GABA}_{A}$ and glycine receptors to extracellular pressure ejection of the corresponding receptor agonists in the presence of $0.5 \mu \mathrm{M} \mathrm{TTX}$, $10 \mu \mathrm{M} C N Q X, 40 \mu \mathrm{M}$ AP5, and $1 \mu \mathrm{M}$ strychnine (Fig. 3.5 A, B) or $1 \mu \mathrm{M}$ bicuculine 
Results

A

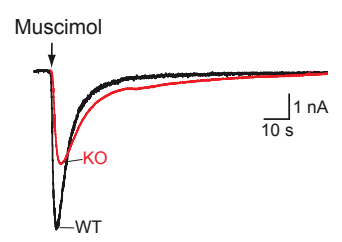

C

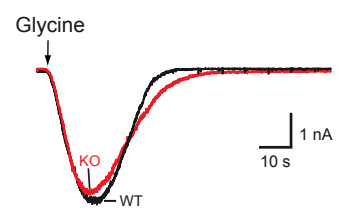

B

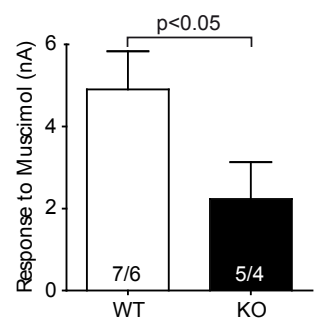

D

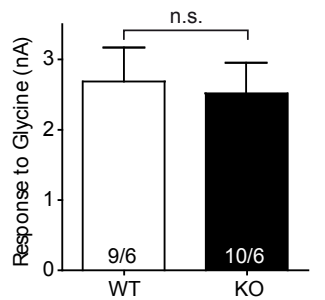

Figure 3.5 The GABA-dependent but not the glycine-mediated postsynaptic receptor response is reduced in MeCP2 KO mice. (A and B) GABA-mediated postsynaptic currents. Sample traces (A) and averaged amplitude (B) of postsynaptic responses to pressure applied GABA agonist muscimol (5 $\mathrm{mM})$ in $\mathrm{KO}$ and littermate WT neurons in the ventrolateral medulla at P7. (C and D) Glycine-mediated postsynaptic currents. Sample traces (C) and averaged amplitude (D) of responses to pressure applied glycine $(5 \mathrm{mM})$ in $\mathrm{KO}$ and WT neurons. Data shown represent mean \pm SEM. Numbers within the bar graphs indicate the number of neurons/ mice tested for each genotype.

(Fig. 3.5 C, D), respectively. Postsynaptic responses to the $\mathrm{GABA}_{\mathrm{A}}$-receptor agonist muscimol $(5 \mathrm{mM})$ were decreased from $4.9 \pm 0.9 \mathrm{nA}$ in WT to $2.2 \pm 0.9 \mathrm{nA}$ in mutant neurons from ventrolateral medulla $(p<0.05$; Fig. $3.5 \mathrm{~B}$ ), suggesting an impairment of functional $\mathrm{GABA}_{\mathrm{A}}$ receptors. In contrast, the response to glycine $(5 \mathrm{mM})$ was almost identical in both genotypes (WT: $2.7 \pm 0.5 \mathrm{nA}, \mathrm{KO}: 2.5 \pm 0.4 \mathrm{nA}$; Fig. $3.5 \mathrm{D}$ ). Interestingly, the absence of changes in glycine-mediated activity might explain the lack of an overt respiratory phenotype because the glycine receptor is essential for respiratory rhythm generation at this developmental age (Richter and Spyer 2001). Since GABA $A_{A}$ receptors that mediate phasic synaptic inhibition predominantly contain a $\gamma 2$ subunit in association with one of the $\alpha 1, \alpha 2$ or $\alpha 3$ subunits $\left(\alpha_{1 / 2 / 3} \beta_{2 / 3} \gamma_{2}\right)$, the $\alpha$

A

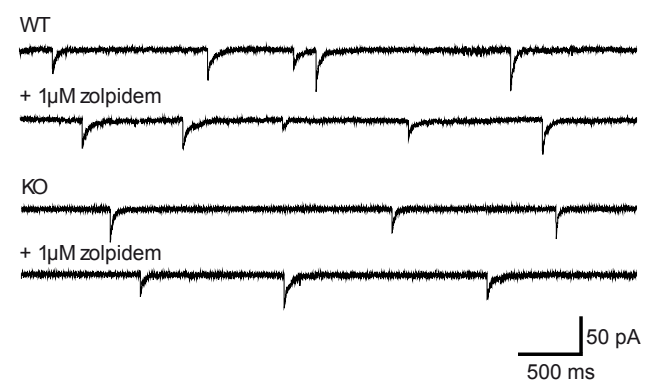

B

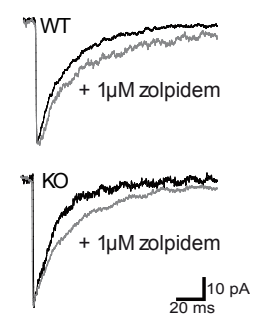

Figure 3.6 Pharmacology of $G A B A_{A}$ receptor subunit $\alpha 1$ is not altered in the absence of MeCP2. (A) Representative traces of miniature GABAergic IPSCs (mGPSC) before and after zolpidem $(1 \mu \mathrm{M})$ application in $\mathrm{WT}$ and $\mathrm{KO}$ neurons from the ventrolateral medulla at P7. (B) Averaged mGPSC currents from WT and KO mice before (black) and after (grey) application of $1 \mu \mathrm{M}$ zolpidem. (C) Averaged decay prolongation induced by zolpidem in WT and KO neurons fails to detect differences in $G_{A B A}$ a1- mediated responses between genotypes. Data shown represent mean \pm SEM. Numbers within the bar graphs indicate the number of mice/neurons tested for each genotype. 
Results

subunit present determines the deactivation kinetics of the receptor currents (Farrant and Nusser 2005). Faster decay times as observed here in MeCP2-mutant mice (Fig. $3.3 \mathrm{I}, \mathrm{J}$ ) could therefore be explained, for example, by an increased expression of $\mathrm{GABA}_{A}$ receptors that contain $\alpha 1$ subunits (McClellan and Twyman 1999; Vicini et al. 1998). To test this possibility, we utilized a specific $G_{A B A}$-receptor agonist, zolpidem, which shows a high affinity for $G_{A B A} \alpha 1$ subunit. In the presence of functional $G_{A B A}$ receptors containing $\alpha 1$ subunit, zolpidem prolongs the decay time of miniature events (Perrais and Ropert 1999). Consistent with these studies, addition of $1 \mu \mathrm{M}$ zolpidem induced a $30 \%$ increase in the decay time of mGPSC in both WT and MeCP2-deficient mice (Fig. 3.6 A-D). While zolpidem did not cause a change in frequency or amplitude (data not shown), the results indicate that an increased expression of postsynaptic $\mathrm{GABA}_{A} \alpha 1$ subunit is unlikely to be responsible for the shortening of the decay time in MeCP2-mutant mice.

A

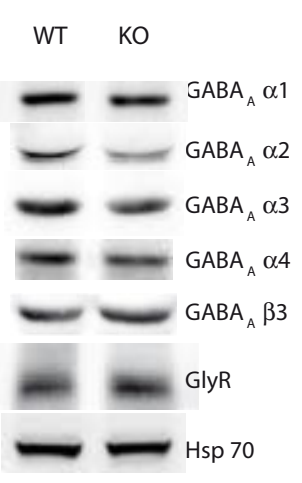

B

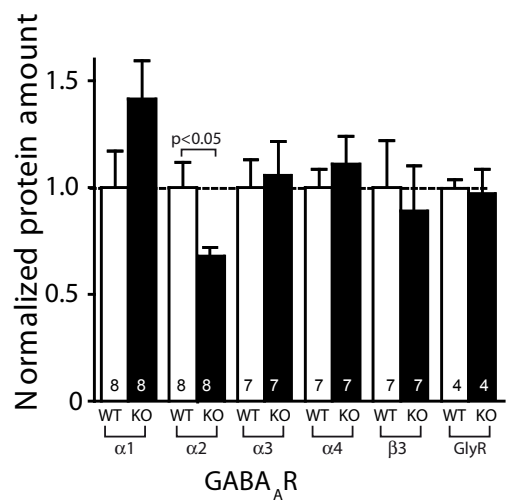

Figure 3.7 Protein levels of the $G A B A_{A}$ a2 receptor subunit are specifically decreased in MeCP2 KO mice. (A) Representative immunoblots of $\mathrm{GABA}_{A}$ receptor subunits a1, a2, a3, a4 and b3, glycine receptor GlyR, and heat shock protein Hsp70 as input control. (B) Quantitative analysis of the protein levels of $\mathrm{GABA}_{A}$ and glycine receptor subunits in brainstem lysates of littermate control (open bars, WT) and MeCP2 deficient mice (closed bars, KO) at postnatal day 7. Data shown represent mean \pm SEM. Numbers within the bar graphs indicate the number of repeats for the respective experiment. Four pairs of littermate WT and KO mice were used for each experiment.

Since pharmacological means to distinguish between different $G_{A B A}$ receptor subunit compositions are very limited, we directly compared the protein levels of different $G_{A B A_{A}}$ receptor subunits and glycine receptors in mutant and WT mice. Quantitative immunoblots of brainstem lysates showed that relative level of the $\mathrm{GABA}_{A} \alpha 2$ subunit was decreased by more than $30 \%(p<0.01)$, while the levels of $\mathrm{GABA}_{A} \alpha 1, \alpha 3, \alpha 4$ and $\beta 3$ subunits, and of glycine receptors were not significantly different between the MeCP2-mutant and the control mice (Fig. 3.7 A and B). 


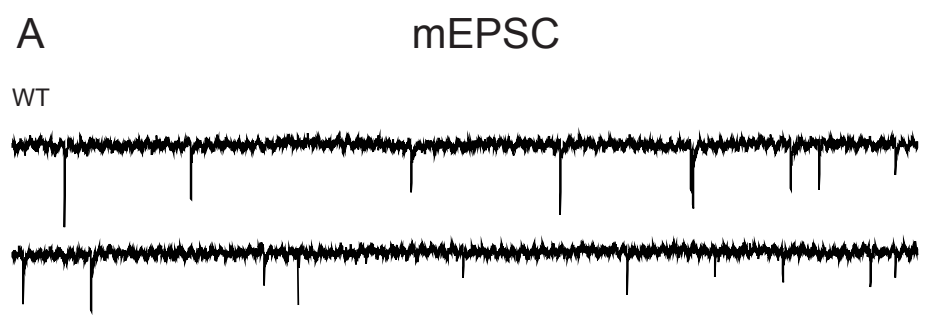

KO
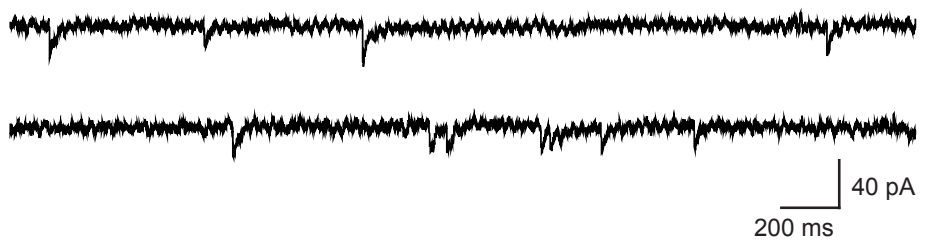

B

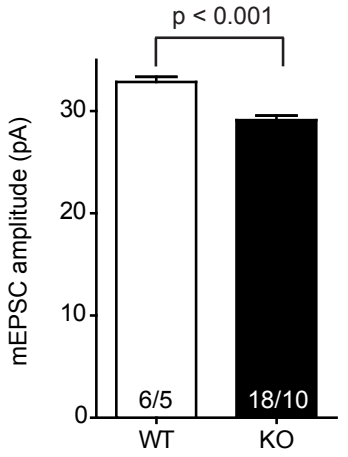

D

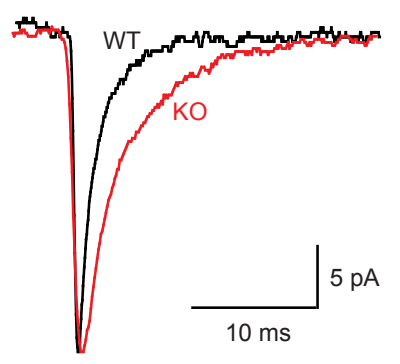

C

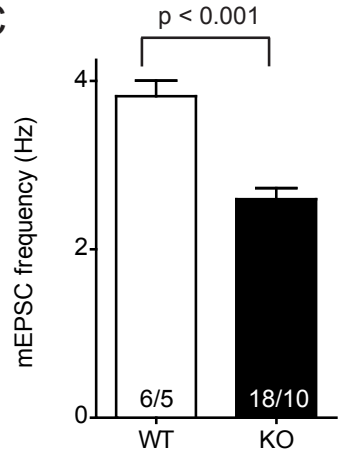

$E$

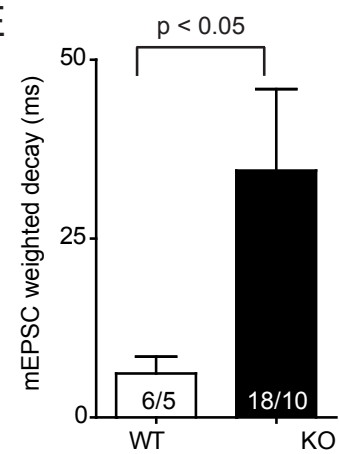

Figure 3.8 Miniature glutamatergic synaptic transmission is reduced in the $\mathrm{NH}$ of MeCP2 KO mice. (A) Representative recordings of pharmacologically isolated miniature glutamatergic PSCs from neurons in $\mathrm{NH}$. (B, C) Averaged amplitude $(E)$ and cumulative distribution of frequency $(F)$ of miniature glutamatergic PSCs in KO and control neurons. (D, E) Sample traces of averaged miniature glutamatergic events (D) and weighted mean decay time from KO and control neurons. Data shown represent mean \pm SEM. Numbers within the bar graphs indicate the number of neurons/mice tested for each genotype.

3.1.6 Miniature excitatory synaptic transmission is depressed in the hypoglossal nucleus of MeCP2 KO mice

Since we noticed that the network excitatory activity is increased in the respiratory brainstem (Fig. 3.1 E-H and Fig. 3.2 A-E) we turned next our attention to the 
Results

investigation of excitatory synapses. In order to analyze if functional synaptic changes are the basis of network related impairments of excitatory (glutamatergic) synaptic transmission described above, we performed miniature excitatory postsynaptic recordings (mEPSCs) in neurons from the hypoglossus nucleus in the presence of $0.5 \mu \mathrm{M}$ tetradotoxin. We chose to record neurons from the $\mathrm{NH}$ nucleus because the presence of all type of excitatory synapses and glutamatergic receptor subunits on

Table 3.2. Kinetics of glutamatergic mini currents in WT and MeCP2 KO neurons

\begin{tabular}{|c|c|c|c|c|}
\hline & $\begin{array}{l}\text { Rise time }(10-90 \%) \\
(\mathrm{ms})\end{array}$ & $\begin{array}{c}\text { Decay time } \\
\text { (ms) }\end{array}$ & $\begin{array}{l}\text { Half-width } \\
\text { (ms) }\end{array}$ & $\begin{array}{c}\text { Area } \\
\left(\mathrm{pA}^{*} \mathrm{~ms}\right)\end{array}$ \\
\hline \multicolumn{5}{|c|}{ mEPSC } \\
\hline WT & $0.8 \pm 0.2$ & $6.2 \pm 2.3$ & $3.2 \pm 1.0$ & $191.1 \pm 41.6$ \\
\hline KO & $1.2 \pm 0.2$ & $34.5 \pm 11.4^{*}$ & $4.6 \pm 0.7$ & $296.0 \pm 60.2$ \\
\hline
\end{tabular}

these neurons has been extensively described (Paarman et al., 2000 and 2005). To our surprise, both the amplitude $(32.8 \pm 0.5 \mathrm{pA}$ in WT and $29.1 \pm 0.4 \mathrm{pA}$ in $\mathrm{KO}$, $p<0.001$, Fig. $3.8 \mathrm{~A}, \mathrm{~B})$ and the frequency $(3.8 \pm 0.2 \mathrm{~Hz}$ in WT and $2.6 \pm 0.1 \mathrm{~Hz}$ in $\mathrm{KO}$, $\mathrm{p}<0.001$, Fig. 3.8 A, C) of mini EPSCs was significantly reduced in neurons from KO mice as compared to neurons from their WT littermates. Moreover kinetic analysis showed that the KO excitatory minis decay significantly slower (Fig. 3.8 D, E) as compared to the ones recorded from WT neurons $(6.1 \pm 2.3 \mathrm{~ms}$ in WT and $34.5 \pm 11.4$ $\mathrm{ms}$ in $\mathrm{KO}, \mathrm{p}<0.05)$. Other kinetic parameters showed no significant change between genotypes (Table 3.2).

\subsubsection{Presynaptic defects of excitatory synapses in the NH nucleus of MeCP2 KO mice}

The significant reduction in the frequency of mEPSCs in the $\mathrm{NH}$ of MeCP2KO mice prompt us to verify if impairments in the synaptic density may be the cause of this phenotype. We performed immunofluorescence staining against the vesicular glutamate transporters 1 and 2 (VGLUT 1 \& VGLUT2). We used slices containing the hypoglossal nucleus of MeCP2 KO mice and their WT littermate controls at P7 (Fig. 3.9 A). Quantification revealed that the area density of VGLUT-positive punctae in the ventrolateral medulla was reduced in MeCP2 KO mice $(8.6 \pm 0.5$ per $\left.100 \mu \mathrm{m}^{2}\right)$ as compared with WT controls (14.9 \pm 0.6 per $100 \mu \mathrm{m}^{2}$; Fig. $\left.3.9 \mathrm{~B}\right)$, 
A
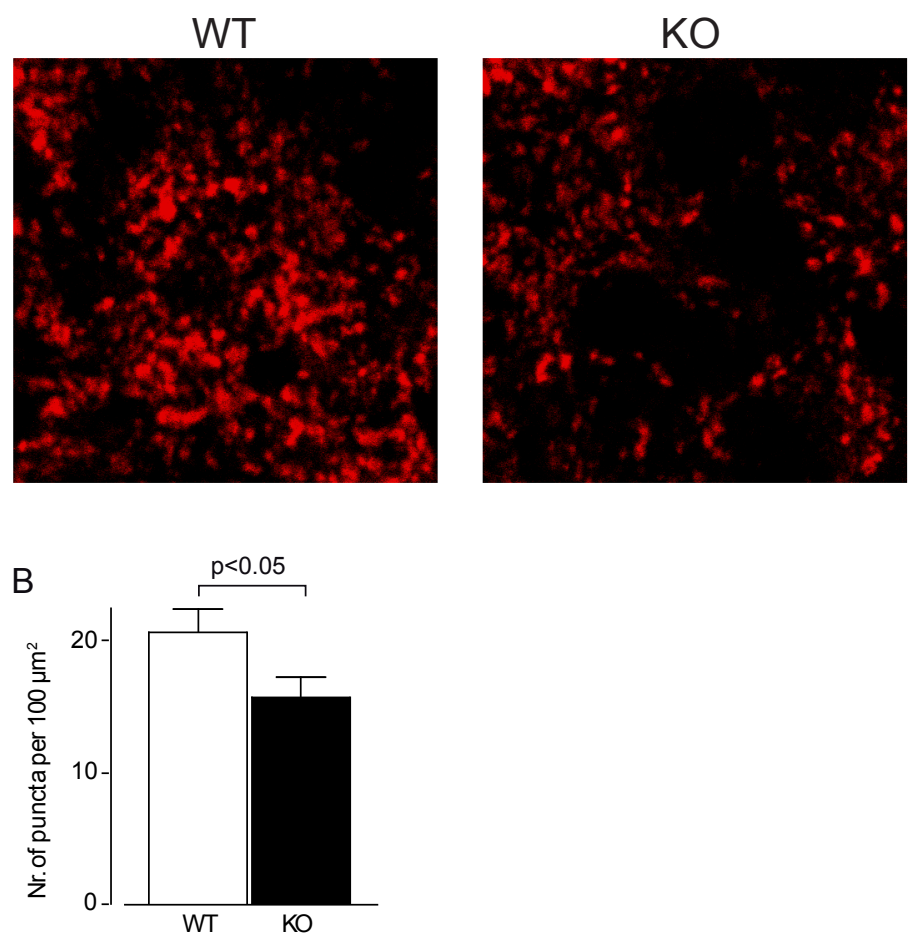

Figure 3.9 Reduced density of excitatory synapses in the NH of MeCP2 KO mice. (A) Representative images of immunofluorescent stainings with anibodies against the vesicular glutamate transporters 1 \& 2 (VGLUT 1 \&2) in the NH from WT and KO mice. (B) Quantification of VGLUTpositive puncta from one WT and one KO mouse. (total number of punctae measured about 400). Data shown represent mean \pm SEM.

with no differences detectable in the background intensity between genotypes. These are preliminary results, but they confirm a previous study that showed that the presynaptic excitatory phenotype on synaptic transmission in autaptic cultures is explained by a reduced number of glutamatergic synapses (Chao et. al., 2007).

\subsubsection{Reduction of specific subunits of NMDA and AMPA receptors in the medulla of MeCP2 KO mice}

lonotropic lutamatergic postsynaptic receptors are separated into 3 major groups: NMDA, AMPA and kainate (Hollmann and Heinemann, 1994). The difference in the amplitude and the decay times of mEPSCs between wild-type and MeCP2 KO mice may be explained by changes in the subunit composition of different glutamatergic postsynaptic receptors. Thus, we performed semiquantitative immunoblot analysis on brainstem homogenates from WT and KO mice, investigating the expression of some important subunits of NMDA and AMPA receptors at this stage of development (Fig. 3.10 A, B) since kainite receptors are weakly expressed in brainstem at this age (Paarman et. al, 2000). NMDAR2A subunit showed a $\sim 60 \%$ reduction in its expression levels (Fig. $3.10 \mathrm{~A}, \mathrm{~B} ; \mathrm{p}<0.05$ ) in the MeCP2 KO mice as compared with 
Results

their wild-type littermates. On the other hand, GluR1 subunit of AMPA receptors showed a mild but significantly increased expression in the medulla of the MeCP2 $\mathrm{KO}$ mice (Fig. 3.10 A, B; p <0.01). None of the other subunit investigated showed significant different expression levels between WT and KO homogenates. The

A

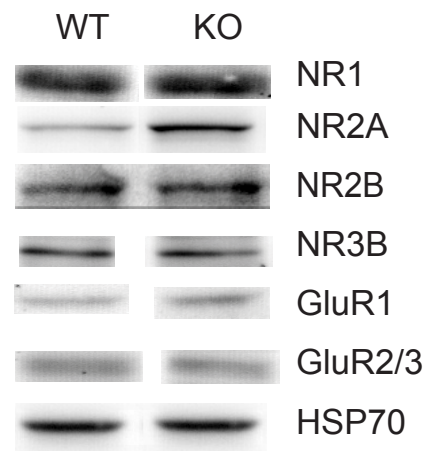

B

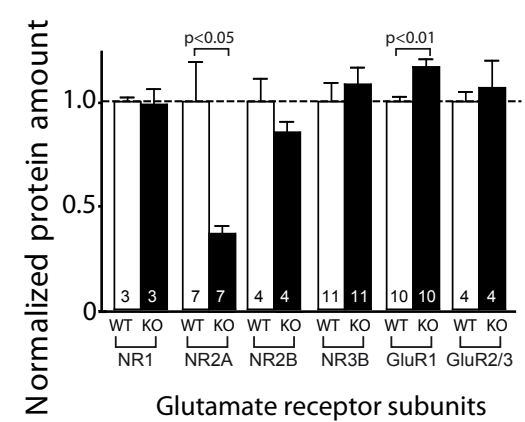

Figure 3.10 Protein levels of glutamate receptor specific subunits are changed in MeCP2 KO mice. (A) Representative immunoblots of NMDA and AMPA receptor subunits with heat shock protein Hsp70 as input control. (B) Quantitative analysis of the protein levels of NMDA and AMPA receptor subunits in medulla lysates of littermate control (open bars, WT) and MeCP2 deficient mice (closed bars, KO) at postnatal day 7. Data shown represent mean \pm SEM. Numbers within the bar graphs indicate the number of repeats for the respective experiment. Four pairs of littermate WT and $\mathrm{KO}$ mice were used for each experiment.

NMDAR2A subunit is the one that confers faster kinetics to NMDA receptors (CullCandy et. al., 2001) and the AMPA receptors have faster decays as well (Hollmann and Heinemann, 1994). Thus, these data are in line with the kinetics data shown above (Fig. 3.8 D, E)

In order to test functionally if the reduction of one subunit of NMDA receptors has an effect on the total membrane expression of the receptor we compared the responses of NMDAand AMPA receptors to extracellular pressure ejection of the corresponding receptor agonists. Experiments were performed on RVLM neurons, in the presence of $0.5 \mu \mathrm{M}$ TTX, $1 \mu \mathrm{M}$ strychnine/bicuculine and $40 \mu \mathrm{M}$ AP5 (Fig. $3.11 \mathrm{~A}, \mathrm{~B}$ ) or 10 $\mu \mathrm{M}$ CNQX (Fig. 3.11 C, D), respectively. Postsynaptic responses to AMPA (5 mM) were similar in WT and mutant neurons from ventrolateral medulla $(1172 \pm 179.3 \mathrm{pA}$ in WT to $993.1 \pm 176 \mathrm{pA}$; Fig. 3.11 A, B). The response to NMDA (5 mM), although it appeared increased in KO RVLM neurons as compared to WT neurons $(225.2 \pm 42.4$ pA in WT and 352.9 \pm 49.7 pA in KO, Fig. 3.11 C, D) was not statistically significant.

\subsubsection{Summary of the MeCP2 KO results}

Our data show that, in the absence of $\mathrm{MeCP} 2$, spontaneous and evoked inhibitory synaptic transmission is reduced in the brainstem respiratory network at P7 (Fig.3.1- 

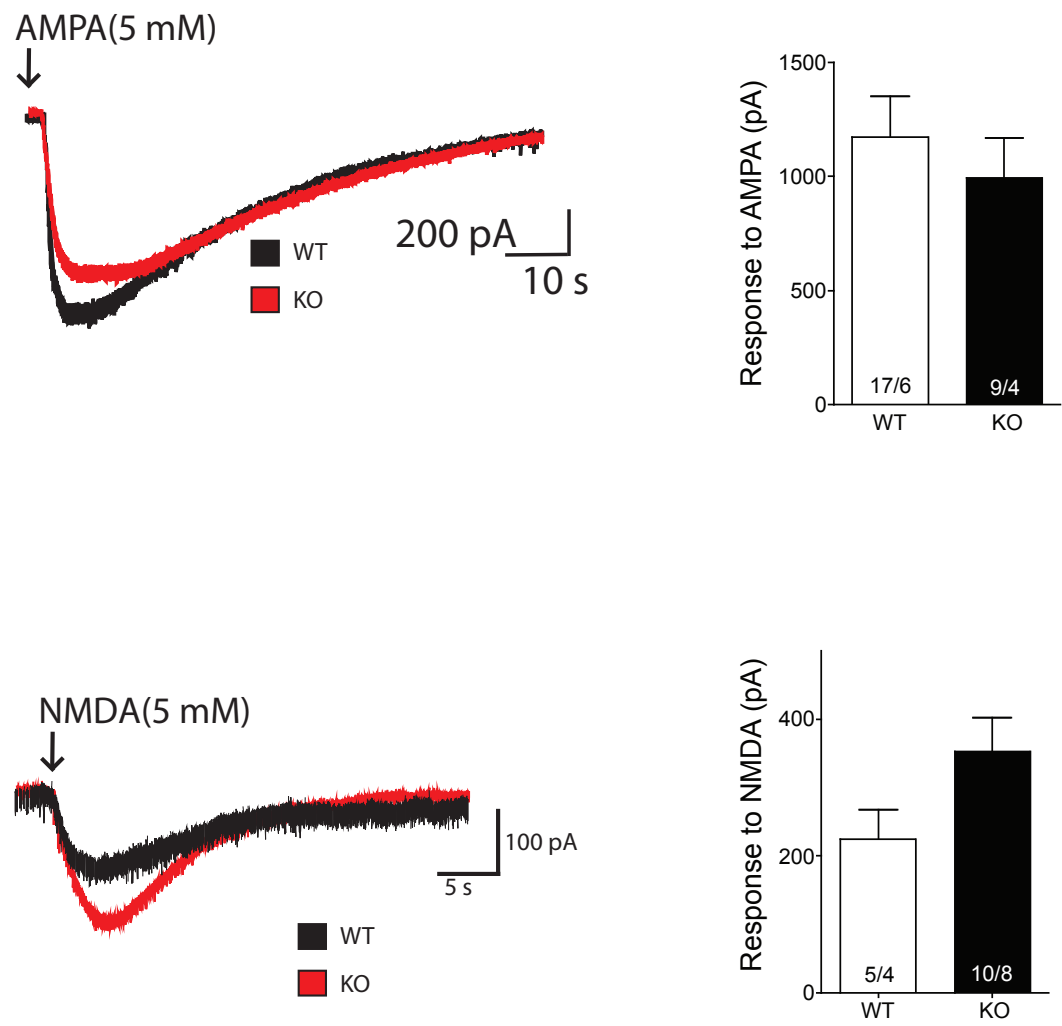

Figure 3.11 The postsynaptic NMDA and AMPA receptor response to direct agonists is unchanged in the RVLM of MeCP2 KO mice. (A and B) AMPA-mediated postsynaptic currents. Sample traces $(A)$ and averaged amplitude (B) of postsynaptic responses to pressure applied AMPA $(5 \mathrm{mM})$ in $\mathrm{KO}$ and littermate WT neurons in the ventrolateral medulla at P7. (C and D) NMDA-mediated postsynaptic currents. Sample traces (C) and averaged amplitude (D) of responses to pressure applied NMDA (5 mM) in KO and WT neurons. Data shown represent mean \pm SEM. Numbers within the bar graphs indicate the number of neurons/mice tested for each genotype.

2). The reduction is due to a specific reduction in the strength of GABAergic, synapses (Fig. 3.3-6). On the other hand both spontaneous and evoked excitatory synaptic transmission is enhanced in the same network (Fig.3.1-2) probably due to changes in network plasticity, since the miniature excitatory synaptic transmission is decreased (Fig.3.8). In MeCP2 KO mice we noticed a decrease in the density of presynaptic markers for inhibitory (VIAAT) (Fig.3.4) and excitatory (VGLUT) synapses (Fig.3.9). At the postsynaptic site, specific alterations of expression levels of GABA and glutamate receptor subunits (Fig. 3.7; Fig. 3.10) are present. From these data, we conclude that MeCP2 is involved in formation and maturation of both excitatory and inhibitory synapses. 


\subsection{NL1 KO mice}

\subsubsection{NL1 KO mice show normal physiology and normal neuronal excitability}

NL 1-3 TKO mice die within hours after birth due to a respiratory failure and published experiments from our group revealed that both glutamatergic and GABA/glycinergic synaptic transmission in the respiratory brainstem are severely reduced (Varoqueaux et. al., 2006). In order to compare the effect that the deletion of NL-1 alone has on ventilation characteristics and/or synaptic function we performed our experiments on postnatal day $1(\mathrm{P} 1)$ using the same experimental paradigms. NL1 KO mice are born normal and there is no difference neither in the appearance nor the body weight between them and their WT and $\mathrm{HZ}$ littermates $(1.7 \pm 0.05 \mathrm{~g}$ in control vs. $1.9 \pm 0.1 \mathrm{~g}$ in KO mice; Fig. 3.12. C). Because the NL TKOs show a severe respiratory failure at this age, we measured the respiratory ventilation by whole-body pletysmography in the NL1 KO mice and their control littermates. No difference could be seen between genotypes $(2.5 \pm 0.1 \mathrm{~Hz}$ in control vs. $2.6 \pm 01$. Hz in KO mice; Fig 3.12. A, B). Next, we recorded voltage-activated $\mathrm{Na}^{+}, \mathrm{K}^{+}$and $\mathrm{Ca}^{2+}$ currents in the $\mathrm{NH}$ and $\mathrm{RVLM}$ neurons in order to see if the deletion of NL1 impairs neuronal excitability. In all cases the density of measured currents was the same between the NL1 KO mice and their control littermates $\left(\mathrm{Na}^{+}: 101.9 \pm 5.9 \mathrm{pA} / \mathrm{pF}\right.$ in control vs. $79.4 \pm 9.7 \mathrm{pA} / \mathrm{pF}$ in $\mathrm{KO}$ mice; $\mathrm{K}^{+}: 135.7 \pm 7.7 \mathrm{pA} / \mathrm{pF}$ in control vs. $157.8 \pm 10.9 \mathrm{pA} / \mathrm{pF}$ in $\mathrm{KO}$ mice; $\mathrm{Ca}^{2+}: 17.8 \pm 1.2 \mathrm{in}$ control vs. $17.6 \pm 1.3$ in $\mathrm{KO}$ mice Fig. $3.13 \mathrm{~A}-\mathrm{F})$.
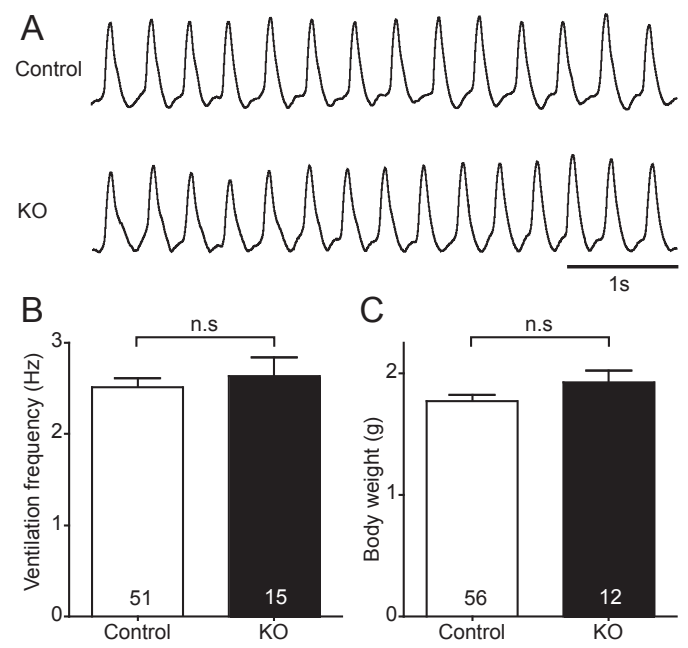

Figure 3.12 Normal physiology of early postnatal NL-1 KO mice. (A, B) Representative ventilation traces $(A)$ and averaged ventilation frequencies $(B)$ of neuroligin mutant mice $(K O)$ and their littermate controls (WT \& HZ) as measured by whole-body plethysmography at postnatal day P2. (C) Averaged body weight of neuroligin mutant mice (KO) and their littermate controls (WT \& HZ). Data shown represent mean \pm SEM. Numbers within the bar graphs indicate the number of mice tested for each genotype. 
A

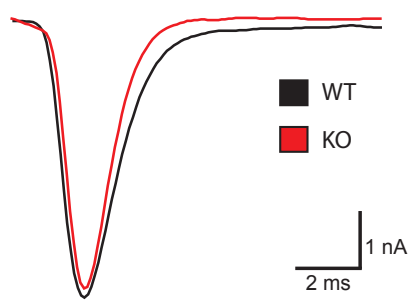

C

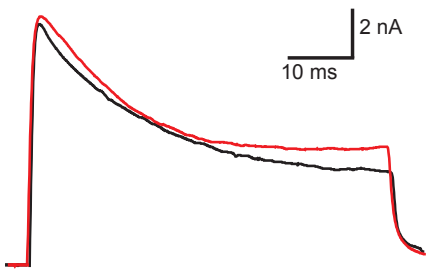

$\mathrm{E}$

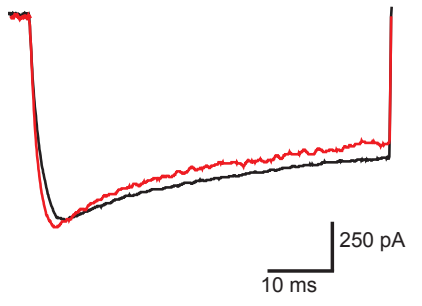

$\mathrm{B}$

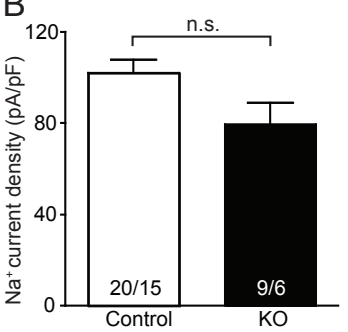

D

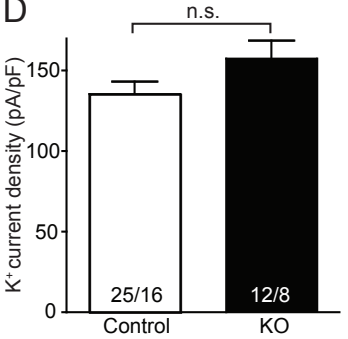

$\mathrm{F}$

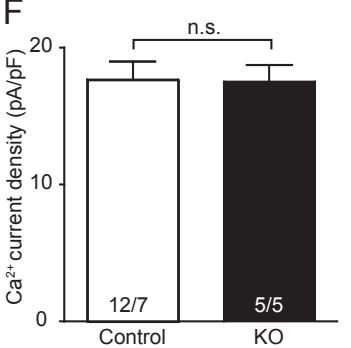

Figure 3.13 Neuronal excitability is normal in NL-1 KO mice. Representative traces of voltageactivated $\mathrm{Na}^{+}(\mathrm{A}), \mathrm{K}^{+}(\mathrm{C})$ and $\mathrm{Ca}^{2+}(\mathrm{E})$ currents and the corresponding mean current densities (B, D, $\mathrm{F}$ ) from $\mathrm{KO}$ and control neurons. Data shown represent mean $\pm \mathrm{SEM}$. Numbers within the bar graphs indicate the number of neurons/mice tested for each genotype.

\subsubsection{Spontaneous, but not miniature GABAergic and glycinergic synaptic transmission is reduced in NL1 KO mice}

Next, we analysed GABAergic and glycinergic synaptic transmission in RVLM neurons since this component of synaptic transmission was the one most affected in the NL TKO mice (Varoqueaux et. al., 2006). Both amplitude and frequency of pharmacologically isolated spontaneous GABAergic and glycinergic PSCs were significantly reduced in the NL1 KO mice as compared with their control littermates (67.5 $\pm 1.5 \mathrm{pA}$ and $3.8 \pm 0.1 \mathrm{~Hz}$ in control vs. $58.9 \pm 1.5 \mathrm{pA}$ and $2.3 \pm 0.1 \mathrm{~Hz}$ in KO mice; $\mathrm{p}<0.001$ in both cases; Fig. 3.14A, B, C). In addition we analysed miniature GABAergic and glycinergic neurons in the same RVLM neurons in the presence of $0.5 \mu \mathrm{M}$ TTX, a blocker of action-potential dependent synaptic transmission. The amplitude and frequency of miniature GABAergic and glycinergic PSCs was unchanged between the genotypes (36.3 $\pm 1.1 \mathrm{pA}$ and $1.1 \pm 0.05 \mathrm{~Hz}$ in control mice vs. $39.2 \pm 1.5 \mathrm{pA}$ and 
A SIPSC

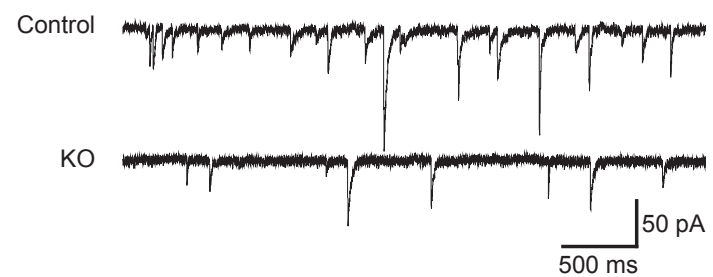

B
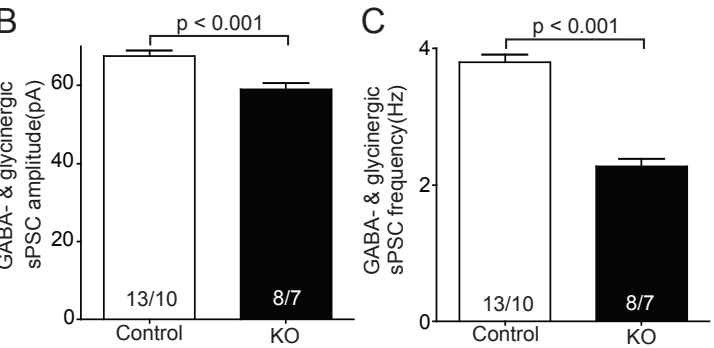

D

mIPSC

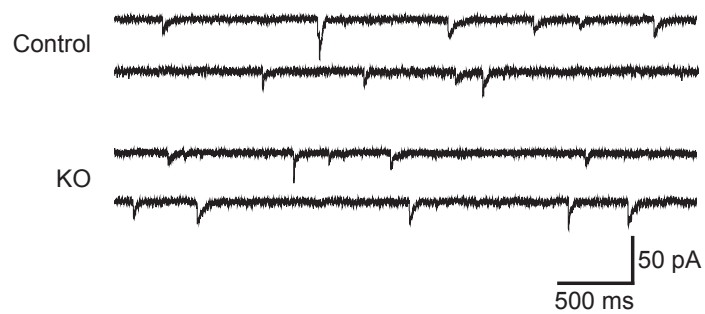

E

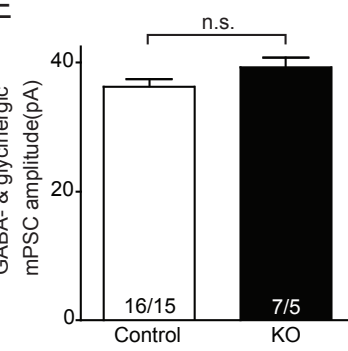

F

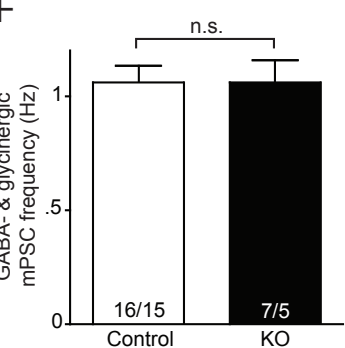

G

$\mathrm{H}$
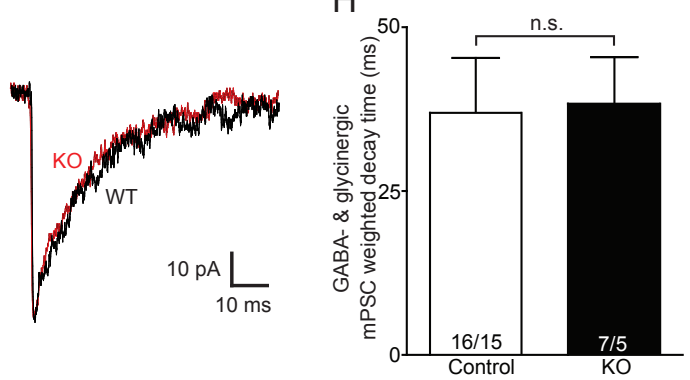

Figure 3.14 GABA- \& glycinergic spontaneous network activity, but not miniature synaptic activity, is reduced in NL-1 KO mice. (A) Representative recordings of pharmacologically isolated spontaneous GABA- \& glycinergic PSCs from neurons in $\mathrm{NH}$. (B, C) Averaged amplitude (B) and frequency (C) of spontaneous GABA- \& glycinergic PSCs in KO and control neurons. (D) Representative recordings of pharmacologically isolated miniature GABA- \& glycinergic PSCs from neurons in RVLM. (E, F) Averaged amplitude (E) and frequency (F) of miniature GABA- \& glycinergic PSCs in $\mathrm{KO}$ and control neurons. $(\mathrm{G}, \mathrm{H})$ Sample traces of averaged miniature GABA- \& glycinergic events (D) and their weighted mean decay time from $\mathrm{KO}$ and control neurons. Data shown represent mean \pm SEM. Numbers within the bar graphs indicate the number of neurons/mice tested for each genotype. 
Results

$1.1 \pm 0.1 \mathrm{~Hz}$ in $\mathrm{KO}$ mice; Fig. 3.14. D, E, F). Furthermore, analysis of mini kinetics did not reveal any difference, nor in decay time $(36.9 \pm 8.4 \mathrm{~ms}$ in control vs. $38.3 \pm 7.1 \mathrm{~ms}$ in $\mathrm{KO}$ mice; Fig. $3.14 \mathrm{G}, \mathrm{H}$ ) neither in other parameters (Table 3.3), suggesting that inhibitory synaptic function is not affected in the NL-1 KO mice.

\subsubsection{Spontaneous, miniature and evoked glutamatergic synaptic transmission is decreased in NL1 KO mice}

Since NL1 is mostly expressed at glutamatergic synapses (Song et al, 1999), we recorded the glutamatergic synaptic transmission in neurons from the hypoglossal nucleus. We pharmacologically isolated glutamatergic PSCs and we noticed that

A

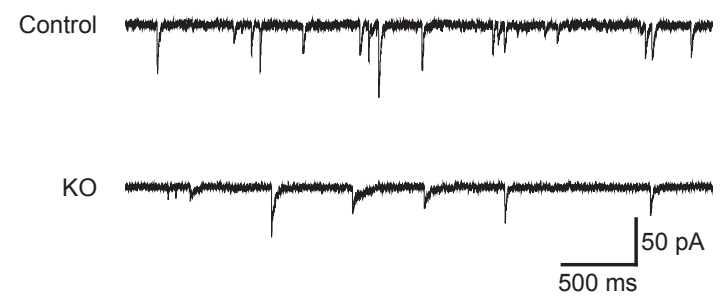

B

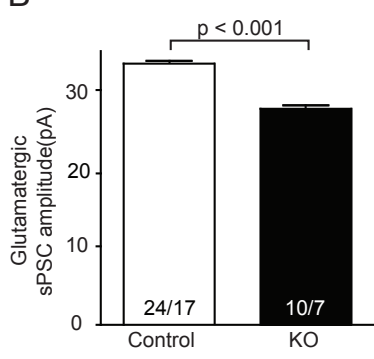

C

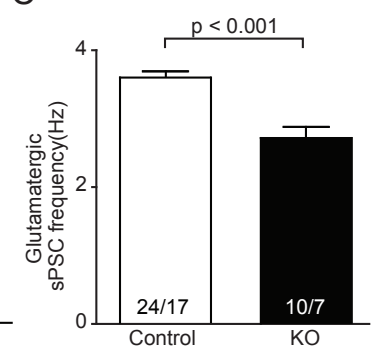

D

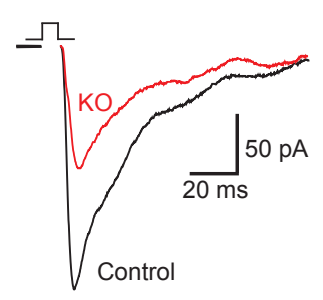

$\mathrm{E}$

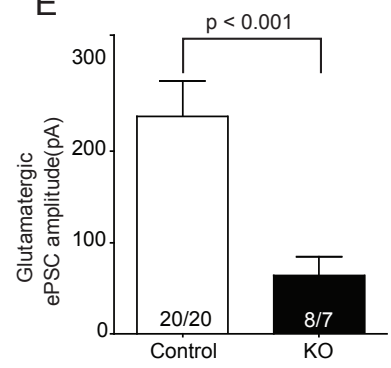

F
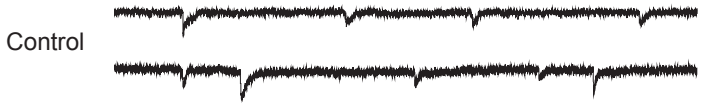

KO

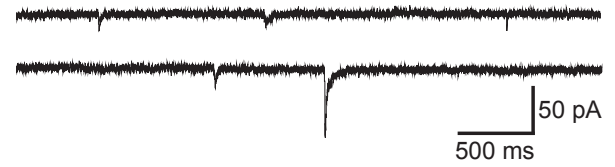

G
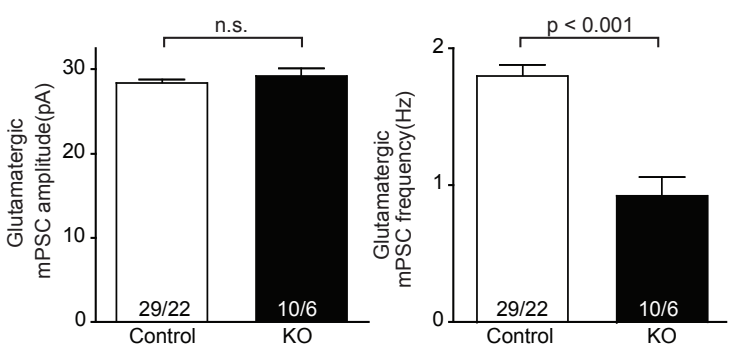

J

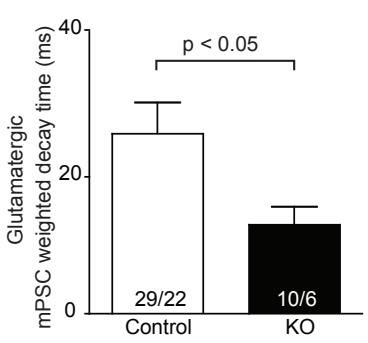

Figure 3.15 Spontaneous, miniature and evoked glutamatergic synaptic transmission is reduced in NL-1 KO mice. (A.) Representative recordings of pharmacologically isolated spontaneous glutamatergic PSCs from neurons in $\mathrm{NH}$. (B, C) Averaged amplitude (B) and frequency (C) of spontaneous glutamatergic PSCs in KO and control neurons. (D, E) Sample traces (D) and averaged amplitude (E) of evoked glutamatergic PSCs in $\mathrm{NH}$ neurons from $\mathrm{KO}$ and control mice. (F) Representative recordings of pharmacologically isolated miniature glutamatergic PSCs from neurons in $\mathrm{NH}$. $(\mathrm{G}, \mathrm{H})$ Averaged amplitude $(\mathrm{G})$ and frequency $(\mathrm{H})$ of miniature glutamatergic PSCs in $\mathrm{KO}$ and control neurons. (I, J) Sample traces of averaged miniature glutamatergic events (I) and their weighted mean decay time from $\mathrm{KO}$ and control neurons. Data shown represent mean \pm SEM. Numbers within the bar graphs indicate the number of neurons/mice tested for each genotype. 
Results

both their amplitude and frequency was significantly reduced in NL1 KO mice as compared with their control littermates $(33.4 \pm 0.4 \mathrm{pA}$ and $3.6 \pm 0.1 \mathrm{~Hz}$ in control vs. 27.7 $\pm 0.4 \mathrm{pA}$ and $2.7 \pm 0.1 \mathrm{~Hz}$ in $\mathrm{KO}$ mice; $p<0.001$ in both cases; Fig. $3.15 \mathrm{~A}-\mathrm{C}$ ). Next we analysed miniature glutamatergic synaptic transmission in $\mathrm{NH}$ neurons in the presence of $0.5 \mu \mathrm{M}$ TTX. While the amplitude of miniature glutamatergic PSCs showed no significant difference between genotypes (28.4 $\pm 0.4 \mathrm{pA}$ in control vs. 29.1 \pm 0.9 pA in KO mice; Fig.3.15 F, G) their frequency was reduced in NL1 KO mice to $~ 50 \%$ of the control values $(1.8 \pm 0.1 \mathrm{pA}$ in control vs. $0.9 \pm 0.1 \mathrm{~Hz}$ in KO mice; p $<0.001$; Fig. $3.15 \mathrm{~F}, \mathrm{H}$ ). Beside the presynaptic phenotype (the $\sim 50$ decrease in frequency) analysis of the decay time of mEPSC revealed a $\sim 50 \%$ reduction in the $\mathrm{KO}$ mice (26.3 $\pm 4.5 \mathrm{~ms}$ in control vs. $13.0 \pm 2.6 \mathrm{~ms}$ in $\mathrm{KO}$ mice; $p<0.05$; Fig. $3.15 \mathrm{I}$, J; Table 3.3). Thus, we chose to electrically evoke glutamatergic PSCs in NH neurons in order to have a different approach to investigate possible postsynaptic changes. For this purpose we stimulated axons from the RVLM neurons and we recorded neurons

Table 3.3. Kinetics of miniature PSCs in control and NL1 KO mice

\begin{tabular}{|c|c|c|c|c|}
\hline & $\begin{array}{l}\text { Rise time }(10-90 \%) \\
(\mathrm{ms})\end{array}$ & $\begin{array}{c}\text { Decay time } \\
(\mathrm{ms})\end{array}$ & $\begin{array}{l}\text { Half-width } \\
\text { (ms) }\end{array}$ & $\begin{array}{c}\text { Area } \\
\left(\mathrm{pA}^{*} \mathrm{~ms}\right)\end{array}$ \\
\hline \multicolumn{5}{|l|}{ mIPSC } \\
\hline Control & $1.6 \pm 0.5$ & $36.9 \pm 8.4$ & $15.1 \pm 2.7$ & $630.3 \pm 98.7$ \\
\hline KO & $1.8 \pm 0.3$ & $38.3 \pm 7.1$ & $16.4 \pm 1.8$ & $883.6 \pm 96.2$ \\
\hline \multicolumn{5}{|l|}{ mEPSC } \\
\hline Control & $1.6 \pm 0.2$ & $26.3 \pm 4.5$ & $5.8 \pm 0.6$ & $300.2 \pm 24.6$ \\
\hline KO & $1.2 \pm 0.2$ & $13.0 \pm 2.6^{*}$ & $4.4 \pm 0.6$ & $241.7 \pm 37.9$ \\
\hline \multicolumn{5}{|l|}{$m N M D A$} \\
\hline Control & $3.2 \pm 0.5$ & $32.9 \pm 3.7$ & $15.3 \pm 1.5$ & $524.0 \pm 51.6$ \\
\hline KO & $2.2 \pm 0.5$ & $22.2 \pm 3.1^{*}$ & $10.0 \pm 1.3^{*}$ & $478.1 \pm 78.4$ \\
\hline \multicolumn{5}{|l|}{ mAMPA } \\
\hline Control & $1.1 \pm 0.1$ & $12.1 \pm 2.4$ & $5.5 \pm 0.6$ & $373.6 \pm 52.7$ \\
\hline KO & $0.9 \pm 0.1$ & $10.9 \pm 3.8$ & $5.2 \pm 1.5$ & $377.1 \pm 61.7$ \\
\hline
\end{tabular}


Results

in the $\mathrm{NH}$ in the presence of $1 \mu \mathrm{M}$ bicuculline and $1 \mu \mathrm{M}$ strychnine. Compared to the evoked glutamatergic PSCs amplitude in neurons from control mice, the amplitude in neurons from NL1 KO mice was strongly decreased $(238.5 \pm 39.0 \mathrm{pA}$ in control vs. 63.7 \pm 20.9 pA in KO mice; Fig. 3.15 D, E).

\subsubsection{NMDA, but not AMPA synaptic transmission is affected in NL1 KO mice}

Since different postsynaptic receptors have different kinetics we decide to further investigate glutamatergic synaptic transmission in the NL-1 KO mice. For this purpose we separately analysed the NMDA and AMPA miniature synaptic transmission in the
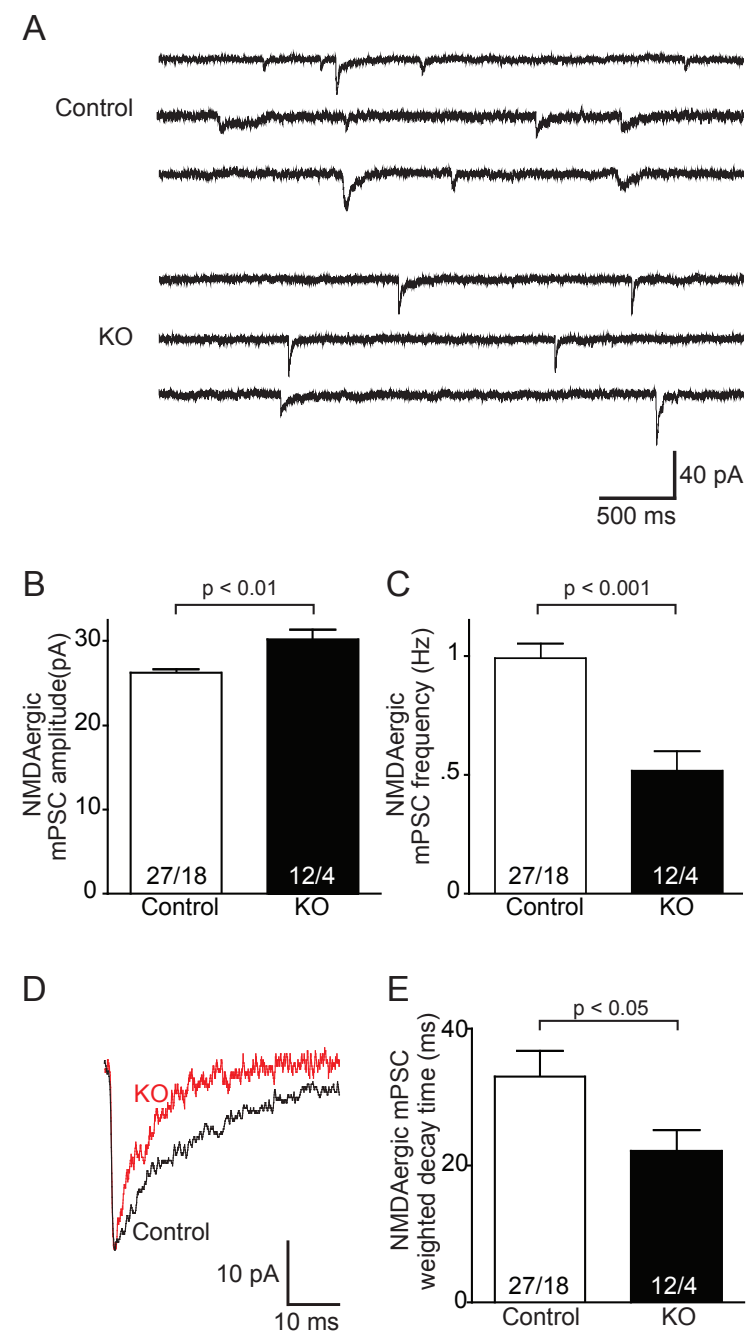

Figure 3.16 NMDAergic miniature postsynaptic currents are impaired in postnatal NL-1 KO mice. (A) Representative recordings of pharmacologically isolated miniature NMDAergic PSCs from neurons in $\mathrm{NH}$. (B, C) Averaged amplitude (E) and cumulative distribution of frequency $(F)$ of miniature NMDAergic PSCs in KO and control neurons. (D, E) Sample traces of averaged miniature NMDAergic events (D) and weighted mean decay time from KO and control neurons. Data shown represent mean \pm SEM. Numbers within the bar graphs indicate the number of neurons/mice tested for each genotype. 
Results

$\mathrm{NH}$ neurons in the presence of $1 \mu \mathrm{M}$ Strychnine, $1 \mu \mathrm{M}$ bicuculline, $0.5 \mu \mathrm{M}$ TTX and 10 $\mu \mathrm{M} C N Q X$ or $40 \mu \mathrm{M}$ AP5. The frequency of miniature NMDA PSCs was reduced in slices from NL KO1 mice to $50 \%$ as compared to slices from their control littermates $(1.0 \pm 0.1 \mathrm{~Hz}$ in control vs. $0.5 \pm 0.1 \mathrm{~Hz}$ in $\mathrm{KO}$ mice; $p<0.001$; Fig. $3.16 \mathrm{~A}, \mathrm{C}$ ), while the frequency of miniature AMPA PSCs was unchanged regardless of the genotype (1.2 $\pm 0.1 \mathrm{~Hz}$ in control vs. $1.1 \pm 0.1 \mathrm{~Hz}$ in $\mathrm{KO}$ mice; Fig. 3.17 A, C). The amplitude of miniature NMDA PSCs was higher in the NL1 KO mice $(26.7 \pm 0.5 \mathrm{pA}$ in control vs. $30.2 \pm 1.1 ; p<0.05$; Fig. 3.16 A, B). On the other side, the amplitude of miniature AMPA PSCs showed no difference in recordings from NL1 KO mice as compared
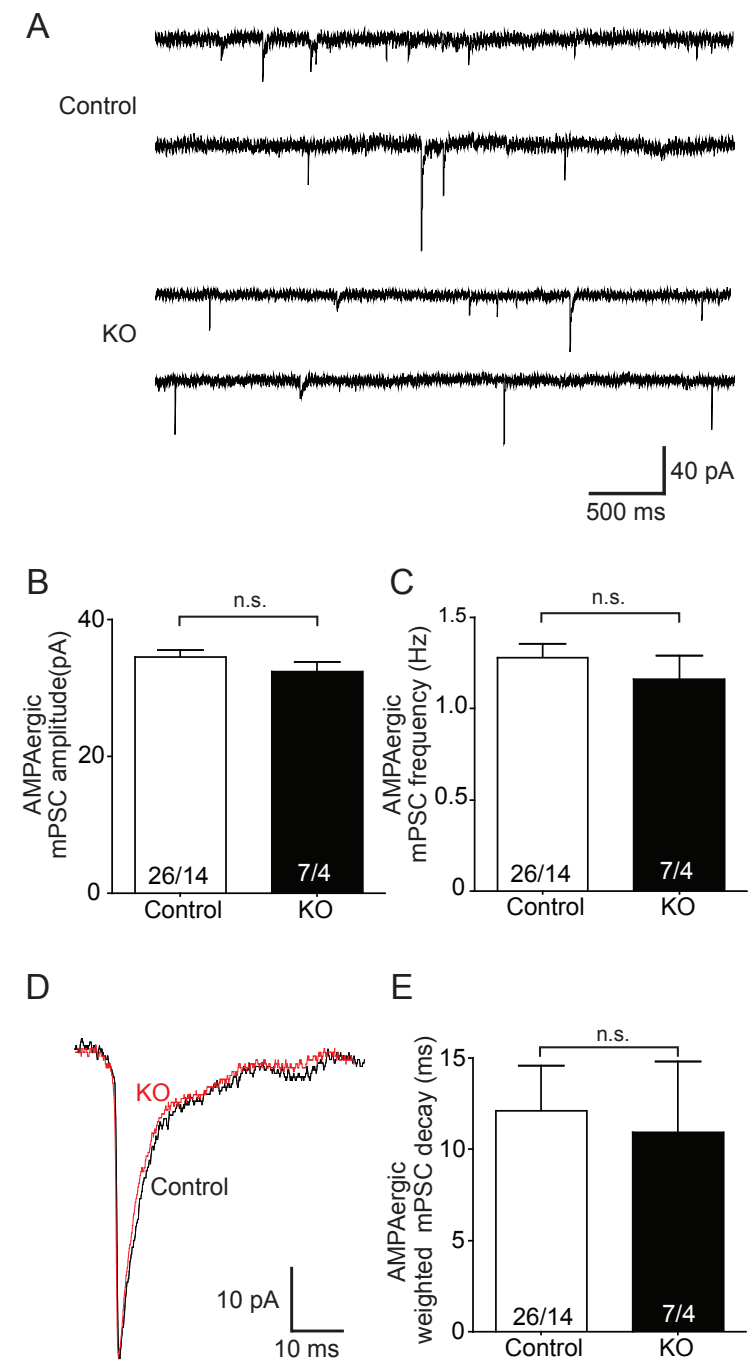

$E$

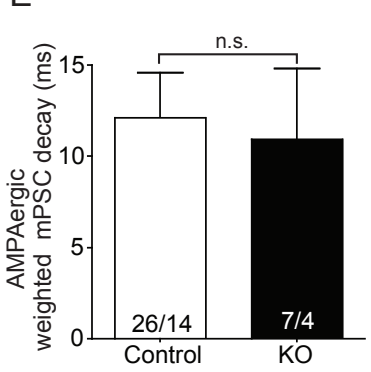

Figure 3.17 AMPAergic miniature postsynaptic currents are normal in postnatal NL-1 KO mice. (A) Representative recordings of pharmacologically isolated miniature AMPAergic PSCs from neurons in $\mathrm{NH}$. (B, C) Averaged amplitude (E) and cumulative distribution of frequency $(\mathrm{F})$ of miniature AMPAergic PSCs in KO and control neurons. (D, E) Sample traces of averaged miniature AMPAergic events (D) and weighted mean decay time from KO and control neurons. Data shown represent mean \pm SEM. Numbers within the bar graphs indicate the number of neurons/mice tested for each genotype. 
with control (34.5 $\pm 1.0 \mathrm{pA}$ in control vs. $32.4 \pm 1.4 \mathrm{pA}$ in KO mice; Fig.17 A, B) and it is most probable that it masked the mEPSC amplitude (Fig. 3.15 F, G). Finally, we analysed the decay times of both miniature NMDA and AMPA PSCs. The decay time of miniature NMDA PSCs was significantly lower in slices from NL1 KO mice (32.9 $\pm 3.7 \mathrm{~ms}$ in control vs. $22.2 \pm 3.1 \mathrm{~ms}$ in KO mice; $p<0.05$; Fig. $3.16 \mathrm{D}$, E; Table 3.3), and it probably underlies the kinetic changes noticed in mEPSC (Fig. $3.15 \mathrm{I}$, J) since the decay of miniature AMPA PSCs was unchanged between genotypes (12.1 $\pm 2.4 \mathrm{~ms}$ in control vs. $10.9 \pm 3.8 \mathrm{~ms}$ in KO mice; Fig.3.17 D, E; Table 3.3).

\subsubsection{Summary of the NL-1 KO results}

The NL-1 KO mice present a reduction in both inhibitory and excitatory spontaneous synaptic transmission, but only changes in the miniature and evoked activity of excitatory synapses were found (Fig. 3.14-15). Moreover, we show that only the function of NMDAergic and not AMPAergic synapses is altered in the absence of NL-1 (Fig. 3.16-17). Altough further experiments need to be done, changes in the frequency, amplitude and decay time of NMDA minis (Fig. 3.16) suggest structural changes in the NMDA synapses. From these data, we conclude that NL-1 plays an important role in the maturation of NMDA synapses. 
Results

\subsection{Nbea KO mice}

\subsubsection{Neurobeachin null-mutant mice die at birth}

Nbea (-/-) were smaller in size and they were easily identified from their wild-type and heterozygous littermates by their prominent hunch (Fig. 3.18). Nbea (-/-) pups were cyanotic, displayed no spontaneous movement and died immediately at birth due to primary asphyxia. The reason for such lethal primary asphyxia in Nbea (-/-) mice might be either failure in the peripheral organogenesis or neuronal impairments in the peripheral and/or central nervous system. In our experiments, the gross anatomy of the most vital organs, such as heart, lung, however, did not show any obvious abnormality (data not shown) that might explain the lethal phenotype. On
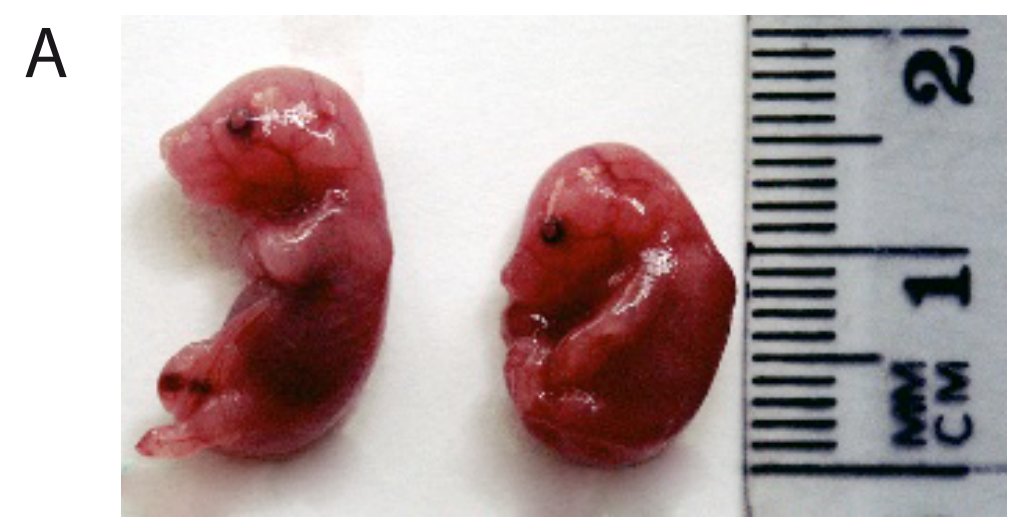

Figure 3.18 Nbea deletion in mice is leading to immediate postcaesarian death. Smaller body size and typical hunch-pack appearance of Nbea-knockout mice (right) at E18 delivered by cesarean section.

the other hand, previous data demonstrated that deletion of Nbea-gene caused a complete block of neuromuscular synaptic transmission (Su et al., 2004). As Nbea is not present in muscle (Su et al., 2004), the primary cause of the lethal asphyxia in Nbea (-/-) mice might be of neuronal nature. We therefore performed a series of experiments on mice of embryonic stage E18-19 obtained by Caesarean section (cf. Methods). In E18-19, Nbea (-/-) mice showed no spontaneous movement and did not react to mechanical stimuli as compare to their heterozygote and WT littermates.

\subsubsection{The function of voltage-activated channels is not altered in Nbea-KO mice}

Since Nbea KO mice die at birth we chose to investigate a brain region that is fully functional at perinatal stage, the respiratory brainstem (Richter and Spyer, 2001). We analyzed different cellular functions in acute slices in two brainstem areas: the preBötzinger complex (preBötC) and the hypoglossal nucleus. This double approach 
Results

ensures that the apparent phenotypes are independent of a particular area or type of synapse. Another advantage of this network is that is well established as a model for studying synaptic maturation in lethal mutant mouse models (Missler et al., 2003; Varoqueaux et. al, 2006).

As mentioned before, Nbea has been proposed to be involved in the post-Golgi sorting or targeting of neuronal membrane proteins, such as proteins of ion-channels, receptors and other membrane proteins. Thus, the lethal phenotype of Nbea-KO mice might be caused by impairment of ion channels in neuronal membranes. To directly test the function of ion channels in Nbea-KO mice, we recorded whole-cell currents of $\mathrm{Na}^{+}-, \mathrm{K}^{+}$- and $\mathrm{Ca}^{2+}$-channels in the pre-Bötzinger area of the brainstem that is essential for generating normal respiratory rhythm (Richter and Spyer, 2001). As shown in Fig. 3.19, whole-cell recordings of voltage-activated $\mathrm{Na}^{+}$-currents were similar between control and KO mice (Fig. 3.19 A, B control: $91.3 \pm 12.5$ pA/pF; KO: $79.3 \pm 8.6 \mathrm{pA} / \mathrm{pF}$; n.s.). Furthermore, no significant changes could be found in current density of either voltage-activated $\mathrm{K}^{+}-$(Fig. $3.19 \mathrm{C}$, D; control: $134.6 \pm 14.4 \mathrm{pA} / \mathrm{pF}$ :

A

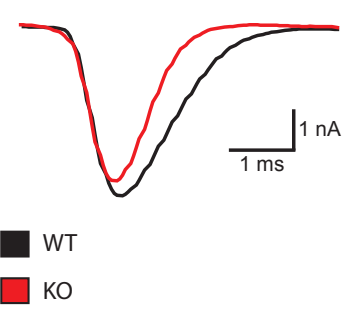

C

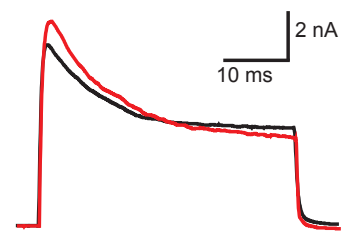

$E$

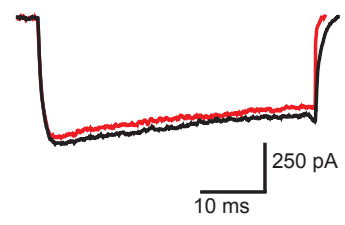

B

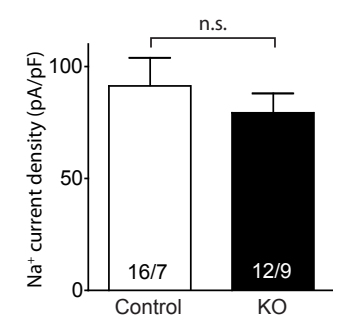

D

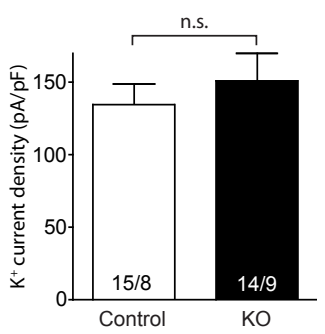

$\mathrm{F}$

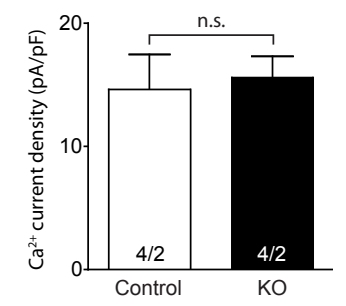

Figure 3.19 Voltage-activated currents are unchanged in Nbea KO mice. Representative traces of voltage-activated $\mathrm{Na}^{+}(\mathrm{A}), \mathrm{K}^{+}(\mathrm{C})$ and $\mathrm{Ca}^{2+}(\mathrm{E})$ currents and the corresponding mean current densities (B, D, F) from wild-type and neurobeachin knockout neurons. Data shown represent mean \pm SEM. The numbers within the bars represent the number of neurons/mice tested. 
A
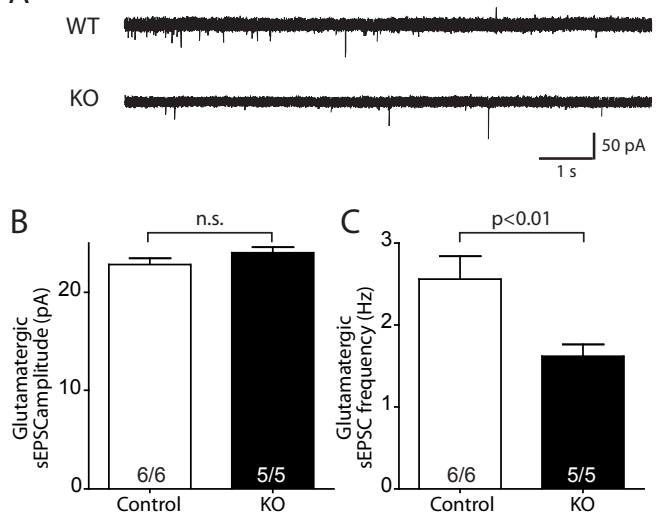

D

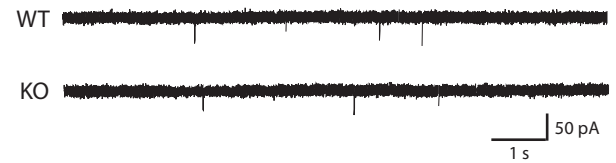

E

$\mathrm{F}$
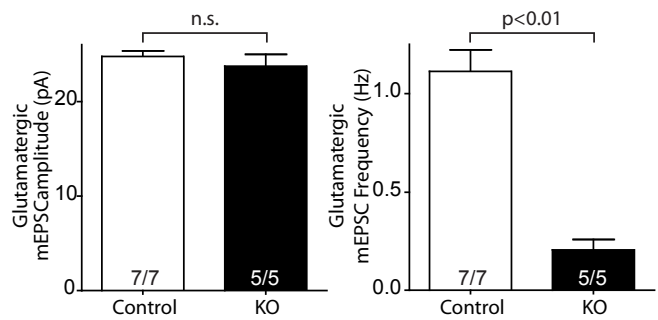

G

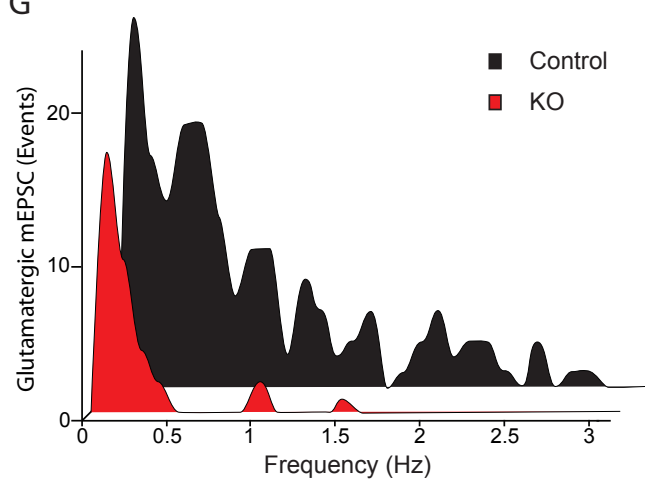

Figure 3.20 Decreased spontaneous and miniature release at glutamatergic synapses in Nbea KO mice. (A) Representative recordings of pharmacologically isolated spontaneous glutamatergic sEPSCs in brainstem RVLM neurons. (B, C) Averaged amplitude (B) and frequency (C) of spontaneous glutamatergic sEPSCs in mutant and WT neurons. (D) Representative recordings of miniature glutamatergic mEPSCs in brainstem RVLM neurons. (E, F) Averaged amplitude (E) and frequency (F) of miniature glutamatergic mEPSCs in mutant and WT neurons. (G) Frequency distribution of glutamatergic mEPSCs in RVLM neurons of littermate control (grey) and neurobeachin KO mice (black). Data shown represent mean \pm SEM. The numbers within the bars represent the number of neurons/mice tested. 
Results

KO: $151.3 \pm 18.6 \mathrm{pA} / \mathrm{pF}$; n.s.) or $\mathrm{Ca}^{2+}$-channels (Fig. $3.19 \mathrm{E}, \mathrm{F}$; control: $14.6 \pm 2.8$

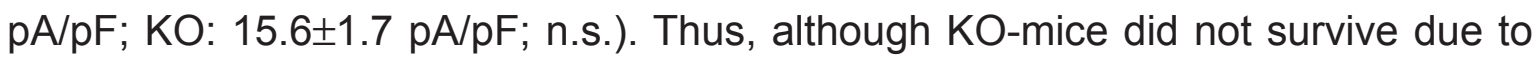
respiratory failure, the neurons were intact and no obvious functional failures could be found in voltage-dependent ion channels within the respiratory network.

\subsubsection{Excitatory synaptic transmission is diminished in Nbea-KO mice}

Neurobeachin expression is highly enriched in the central nervous system (Wang et al.) and we reasoned that central synapses could be affected in the absence of Nbea. To direct challenge the question whether deletion of Nbea-gene might compromise the targeting of synaptic proteins and thus also the synaptic function, we next monitored the spontaneous excitatory postsynaptic currents (sEPSCs) using whole-cell recording in neurons of hypoglossal nucleus in the presence of $1 \mu \mathrm{M}$ bicuculine and $1 \mu \mathrm{M}$ strychnine. The frequency of sEPSCs in hypoglossal neurons was decreased in Nbea-KO mice (Fig. $3.20 \mathrm{~A}$, C; control: $2.5 \pm 0.3 \mathrm{~Hz}$; KO: $1.6 \pm 0.2$ $\mathrm{Hz} ; \mathrm{p}<0.01$ ), while the amplitude was not affected (Fig. 3.20 A, B; control: 22.8 \pm 0.6 pA; KO: $23.8 \pm 0.5 \mathrm{pA}$; n.s.). We further analyzed miniature excitatory postsynaptic currents (mEPSC) in the presence of $0.5 \mu \mathrm{M}$ TTX. The frequency of mEPSC was clearly reduced in Nbea-KO mice (Fig. 3.20 D, F, G; control: 1.1 \pm 0.1 ; KO: $0.2 \pm 0.05$; $p<0.001$ ), but the amplitude of mEPSCs was not significantly changed between the genotypes (Fig. 3.20 D, E; control: $24.7 \pm 0.6$ pA: KO: $23.7 \pm 1.3$ pA; n.s.). In addition, analysis of the kinetics of mEPSCs revealed also no significant difference between the $\mathrm{KO}$ and the control group (see Table 3.4).

\subsubsection{Inhibitory synaptic transmission is severely compromised in Nbea-KO mice}

It is known that inhibition is essential for respiratory rhythm generation (Richter and Spyer, 2001) and the majority of synapses within the respiratory network is in fact inhibitory (McKay et al., 2005). We therefore monitored spontaneous glycine- and GABAergic inhibitory postsynaptic currents (sIPSCs) in preBötC neurons in the presence of $10 \mu \mathrm{M} \mathrm{CNQX}$ and $40 \mu \mathrm{M}$ APV. Here both the amplitude (Fig. 3.21 A, B; control: $93.7 \pm 5.8 \mathrm{pA} ; \mathrm{KO}: 33.7 \pm 6.7 \mathrm{pA} ; \mathrm{p}<0.001$ ) and the frequency (Fig. 3.21 A, C; control: $2.1 \pm 0.2 \mathrm{~Hz}$; KO: $0.35 \pm 0.1 \mathrm{~Hz}$; $p<0.001$ ) of sIPSCs in preBötC neurons were dramatically diminished in neurobeachin $\mathrm{KO}$ mice. This dramatic decrease in the spontaneous inhibitory network activity together with changes in excitatory transmission (Fig. 3.19) is probably the reason for the lethal respiratory failure in the Nbea KO mice (Richter and Spyer, 2001).

The above conspicuous changes in the sIPSCs could be caused by either pre- or/ and postsynaptic defects. To answer this question we further analyzed the miniature, 
A
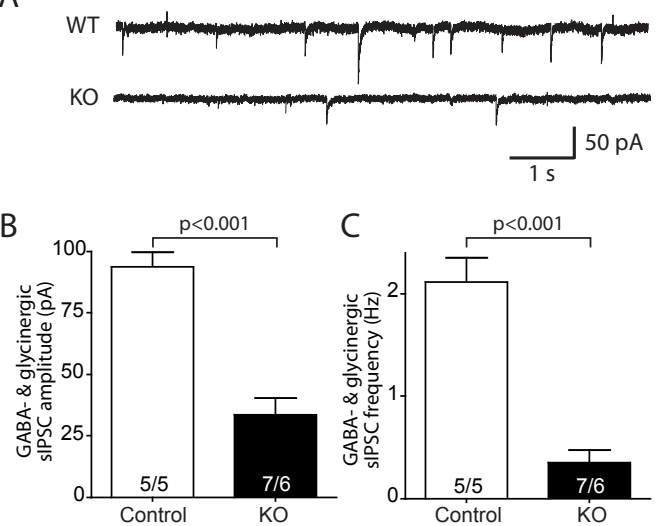

$\mathrm{D}$
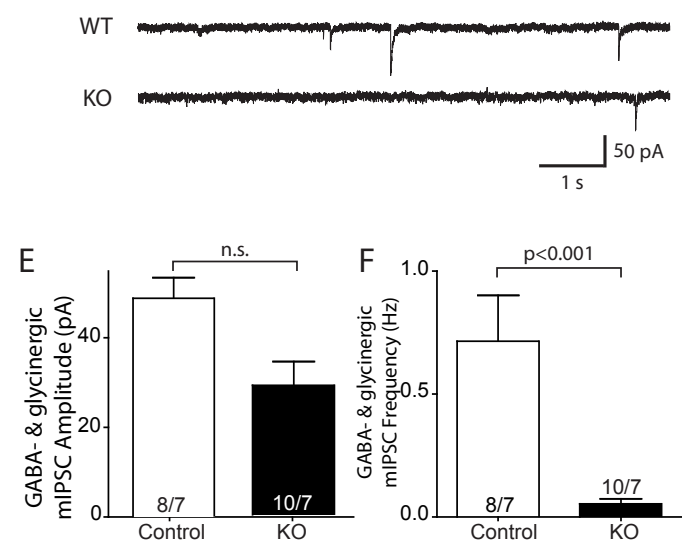

G

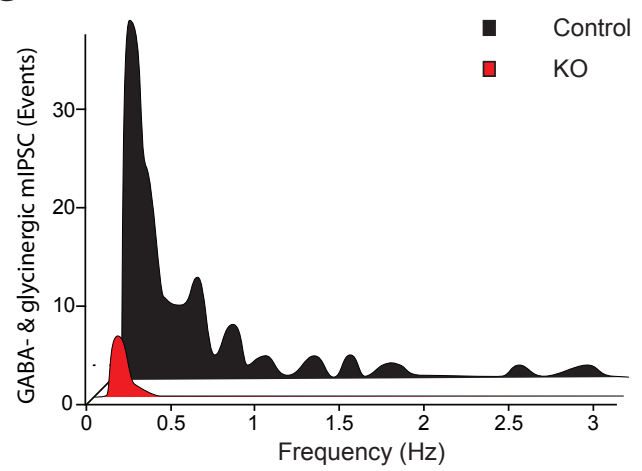

Figure 3.21 Deletion of neurobeachin almost abolishes inhibitory synaptic transmission. (A) Representative recordings of pharmacologically isolated spontaneous glycine- and GABAergic sIPSCs in brainstem RVLM neurons. $(B, C)$ Averaged amplitude $(B)$ and frequency $(C)$ of spontaneous glycine- and GABAergic sIPSCs in mutant and WT neurons. (D) Representative recordings of miniature glycine- and GABAergic sIPSCs in brainstem RVLM neurons. (E, F) Averaged amplitude $(E)$ and frequency $(F)$ of miniature glycine- and GABAergic sIPSCs in mutant and WT neurons. (G) Frequency distribution of glycine- and GABAergic mIPSCs in RVLM neurons of control (grey) and neurobeachin KO mice (black). Data shown represent mean \pm SEM. The numbers within the bars represent the number of neurons/mice tested. 
Results

action-potential independent, glycine- and GABAergic inhibitory postsynaptic currents (mIPSCs) in the presence of $0.5 \mu \mathrm{M}$ TTX. The frequency of mIPSCs in Nbea KO mice was so dramatically decreased (Fig. 3.21 D, F; control: $0.7 \pm 0.2$ $\mathrm{Hz}$; KO: $0.05 \pm 0.04 \mathrm{~Hz} ; \mathrm{p}<0.001$ ) that the miniature events were almost totally abolished in KO mice (Fig. $3.21 \mathrm{G}$ ). Despite the depletion of mIPSCs, the amplitudes

Table 3.4. Kinetics of miniature PSCs in control and Nbea KO mice

\begin{tabular}{ccccc}
\hline & $\begin{array}{c}\text { Rise time (10-90\%) } \\
(\mathbf{m s})\end{array}$ & $\begin{array}{c}\text { Decay time } \\
(\mathbf{m s})\end{array}$ & $\begin{array}{c}\text { Half-width } \\
(\mathbf{m s})\end{array}$ & $\begin{array}{c}\text { Area } \\
\left(\mathbf{p A}^{*} \mathbf{m s}\right)\end{array}$ \\
\hline mIPSC & & & & \\
\hline Control & $2.0 \pm 0.6$ & $46.2 \pm 13.0$ & $11.5 \pm 0.9$ & $715.6 \pm 166.8$ \\
\hline KO & $2.2 \pm 0.5$ & $29.9 \pm 13.5$ & $10.0 \pm 1.8$ & $652.2 \pm 266.3$ \\
\hline mEPSC & & & & \\
\hline Control & $1.7 \pm 0.4$ & $32.5 \pm 18.0$ & $5.9 \pm 1.0$ & $293.9 \pm 49.8$ \\
\hline KO & $1.6 \pm 0.5$ & $23.8 \pm 9.5$ & $3.4 \pm 0.4$ & $171.7 \pm 26.7$ \\
\hline
\end{tabular}

of the remaining miniature events were only moderately decreased in $\mathrm{KO}$ mice (Fig. 3.21 D, E; control: $44.4 \pm 4.2 \mathrm{pA}$; KO: $25.3 \pm 4.9 \mathrm{pA}$; $p<0.01$ ), whereas no significant changes were noticed in the kinetic parameters of the mIPSC between the KO and control mice (see Table 3.4). These data, thus, suggest rather a presynaptic defects in $\mathrm{KO}$ mice.

To exclude the possibility of a postsynaptic defect, we compared the responses of glycine receptors to extracellular pressure ejection of $5 \mathrm{mM}$ glycine in the presence of $0.5 \mu \mathrm{M}$ TTX, $10 \mu \mathrm{M}$ CNQX, $40 \mu \mathrm{M}$ AP5, and $1 \mu \mathrm{M}$ bicuculine. The amplitude of the response to glycine was similar between genotypes (Fig. 3.22 A, B; control: $2.22 \pm 0.8 \mathrm{nA}$; KO: $1.55 \pm 0.3 \mathrm{nA}$; n.s.), suggesting no significant changes in the postsynaptic site in the absence of neurobeachin.

The next question was whether the impairment of SIPSCs and mIPSCs in neurobeachin $\mathrm{KO}$ mice reflects a fundamental dysfunction of synapses that particularly applies to action potential evoked transmitter release. We examined evoked IPSCs of neurons of hypoglossal nucleus in presence of $10 \mu \mathrm{M} C N Q X$ and $40 \mu \mathrm{M}$ APV by extracellular field stimulation of preBötC neurons. Compared to control mice, the averaged amplitude of elPSCs did not change significantly in Nbea KO mice (Fig. 3.22 C, D; control: $118.7 \pm 54.8 \mathrm{pA}$; KO: $93.7 \pm 55.3 \mathrm{pA}$; n.s.). On the other hand, the failure 
A

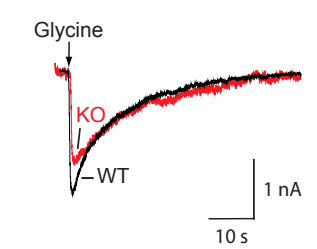

C

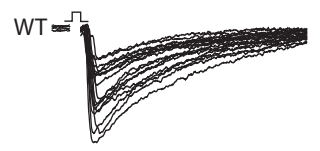

D

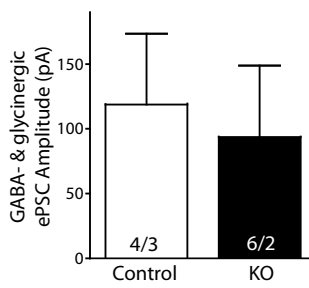

B
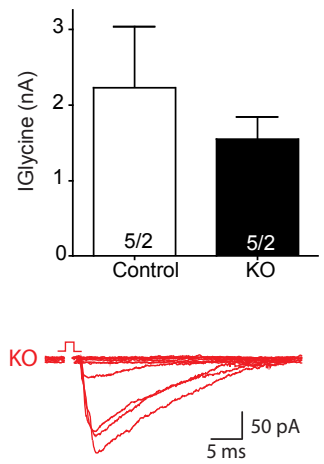

$\mathrm{E}$

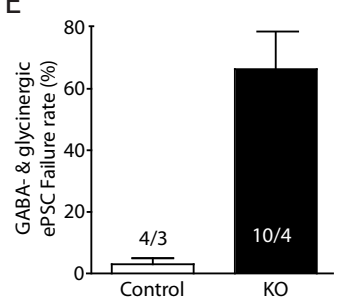

Figure 3.22 Increased failure rate with intact postsynaptic receptors characterize inhibitory synapses of Nbea KO mice. Sample traces (A) and averaged amplitudes (B) of brainstem RVLM neurons in mutant and WT mice in response to pressure-ejected glycine. Sample traces (C), failure rates (D), and averaged amplitudes (E) of evoked glycine- and GABAergic IPSC in mutant and WT neurons in response to extracellular stimulation. Data shown represent mean \pm SEM. The numbers within the bars represent the number of neurons/mice tested.

rate of stimulation evoked IPSCs manifested from $3 \pm 1.9 \%$ in control mice to 66.4 $\pm 11.8 \%$ in KO mice ( $p<0.001$; Fig. $3.22 \mathrm{E}$ ). Taken together, these data point to presynaptic defects in both inhibitory and excitatory synaptic transmission.

\subsubsection{Modified abundance of multiple synaptic proteins in Nbea KO mice}

In order to find the cellular clues of the reported functional impairments in the Nbea$\mathrm{KO}$ mice, we analysed the expression levels in whole-brainstem lysates of several pre- and postsynaptic protein markers by using quantitative Western blotting. Among the 15 presynaptic proteins tested, the relative levels of the synaptophysin and synapsin I\&II, which are among the most abundant components of synaptic vesicles (Takamori et al, 2006) were reduced to $\sim 50 \%$ in Nbea KO mice. In addition, SV2 and Mint-1 were also significantly decreased, while the levels of other proteins were unchanged in mutant mice (Fig. 3.23 A, B). There were also no significant changes in the levels of the vesicular transporters VIAAT and VGAT between the KO and the control group. At the postsynaptic site, the levels of tested NMDAR1 subunits were significantly decreased, while the levels of other postsynaptic proteins tested were not significantly different between the Nbea-mutant and the control mice (Fig. 3.23 A, B). 


A NBea $+/+$-/-
\begin{tabular}{|c|l|}
\hline PRESYNAPTIC PROTEINS \\
\hline Synaptophysin & \\
\hline Synaptobrevin & \\
\hline Synaptotagmin & \\
\hline Synapsin 1\&2 & \\
\hline Rab3A & \\
\hline Syntaxin1 & \\
\hline SV2 & \\
\hline SNAP25 & \\
\hline VGLUT1 & \\
\hline VIAAT & \\
\hline Munc18 & \\
\hline Mint1 & \\
\hline
\end{tabular}

\begin{tabular}{|} 
NBea + +/ -/- \\
\begin{tabular}{|c|l|}
\hline Synaptoporin & \\
\hline Dynamin & \\
\hline Complexin II & \\
\hline \multicolumn{2}{|c|}{ POSTSYNAPTIC PROTEINS } \\
\hline Gephyrin & \\
\hline GABAR 1 & \\
\hline GlyR & \\
\hline PSD-95 & \\
\hline NMDAR 54.1 & \\
\hline NMDAR 54.2 & \\
\hline \multicolumn{2}{|c|}{ CONTROL PROTEINS } \\
\hline ACtin & \\
\hline HSP 70 & \\
\hline
\end{tabular}
\end{tabular}

B

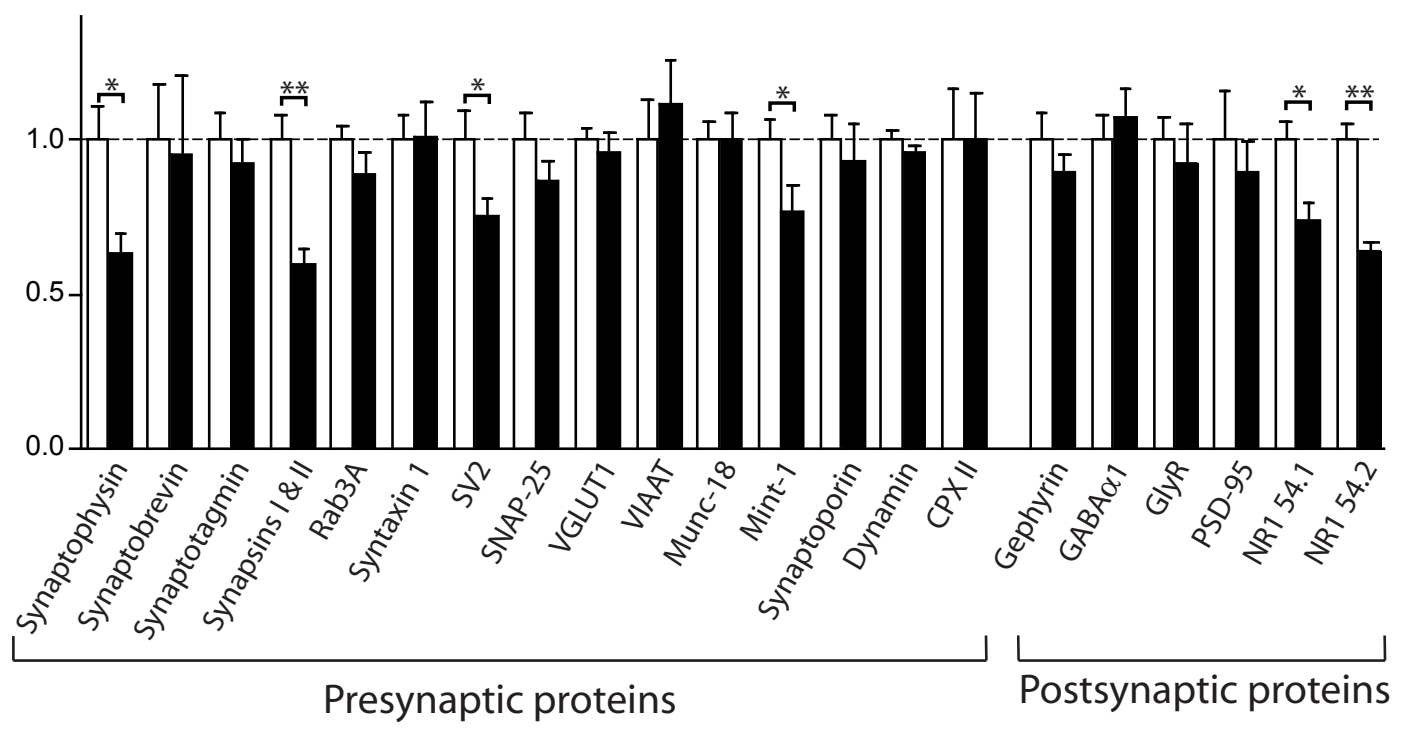

Figure 3.23 Expression levels of several synaptic marker proteins are decreased in Nbea KO mice. (A) Representative immunoblots of pre- and postsynaptic proteins in WT and Nbea KO mice, using actin and heat shock protein (Hsp70) as input control. (B) Quantitative analysis of the protein levels from brainstem lysates of littermate wild-type (open bars, WT) and Nbea-deficient mice (closed bars, KO) at embrionyc day E18. Data shown represent mean \pm SEM. Three pairs of littermate WT and $\mathrm{KO}$ mice were used for each experiment. 
Results

\subsubsection{Summary of the Nbea KO results}

Deletion of Nbea causes a significant reduction of both excitatory and inhibitory evoked and spontaneous synaptic transmission in the respiratory brainstem (Fig. 3.20-22), leading to immediate postnatal death. Analysis of miniature currents showed that the function of both inhibitory and excitatory synapses is severely reduced (Fig. 3.2021) The perturbed excitatory and inhibitory synaptic transmission in Nbea KOs is due to altered pre- and postsynaptic functions (Fig. 3.20, 3.21, 3.22) that most likely caused by aberrant cell surface and synaptic recruitment of presynaptic proteins and postsynaptic receptors (Fig. 3.23). Moreover, work done by our collaborators show that deletion of Nbea also leads to a reduction of both the number of synapses and the number of transmitter vesicles in presynaptic terminals (Fig.4.2). Thus, we show that $\mathrm{Nbea}$ is an essential protein for the formation of inhibitory and excitatory central synapses. 


\section{Discussions}

\subsection{Synaptic imbalance appears early in the developing neural networks of mice models of ASD}

\subsubsection{Inhibition is the functional driving force of the respiratory network}

We performed the experiments in the present study on unidentified neurons within the ventrolateral medulla that contains both respiratory and none-respiratory neurons. Nevertheless, since it was shown that the majority of the neurons from this structure are involved in respiration (Smith et. al., 1991) it is quite likely that the results of the present study do apply for respiratory rhythm-generating network.

Both RTT patients and MeCP2 KO mice suffer from respiratory irregularities (Chahrour et. al., 2007). Our analysis of MeCP2 KO mice demonstrate that inhibitory and excitatory spontaneous and evoked network activity in the RVLM and NH is already altered in early postnatal mutant mice (Fig. 3.1), however no obvious impairment in the overall ventilation activity was evident at this age (Viemari et al. 2005). As for the NL-1 KO mice, although both inhibitory and excitatory synaptic transmission was reduced, no changes in ventilation activity were noticed (Fig. 3.12-14), in contrast with the ventilation irregularities found in the NL-2 KO mice (Aramuni et.al., in review) or with the respiratory failure that accompanies the deletion of NL-1, 2 and 3 (Varoqueaux et al., 2006). In the case of Nbea-KO mice the severe impairment of excitatory and especially inhibitory synaptic transmission in brainstem respiratory network (Fig. 3.20-21) is probably leading to apnea. We conclude that, the central respiratory failure together with the general peripheral paralysis causes the early lethal phenotype of the Nbea (-/-) mice.

The absence of overt respiratory problems in the case of MeCP2 and NL-1 KO mice may be surprising with respect to such a strong cellular phenotype, however, the respiratory network is known to be one of the most robust networks due to the redundant assembly of its connectivity that confers stability against disturbances (Feldman and Del Negro 2006; Richter and Spyer 2001). As we notice in the case of the Nbea KO mice or in the previous studies of neuroligin-2 KO mice (Aramuni et.al., in review), neurexin triple KO mice (Missler et al., 2003) and neuroligin triple KO mice (Varoqueaux et al., 2006), a reduction of inhibitory network activity of $50 \%$ or more was necessary to cause first visible irregularities in the resting ventilation activity (Aramuni et.al., in review), and only a reduction of more than $80 \%$ caused a life-threatening failure of ventilation (Missler et al., 2003; Varoqueaux et al., 2006) (Fig. 4.1). As inhibition is an essential process for the neurons from 


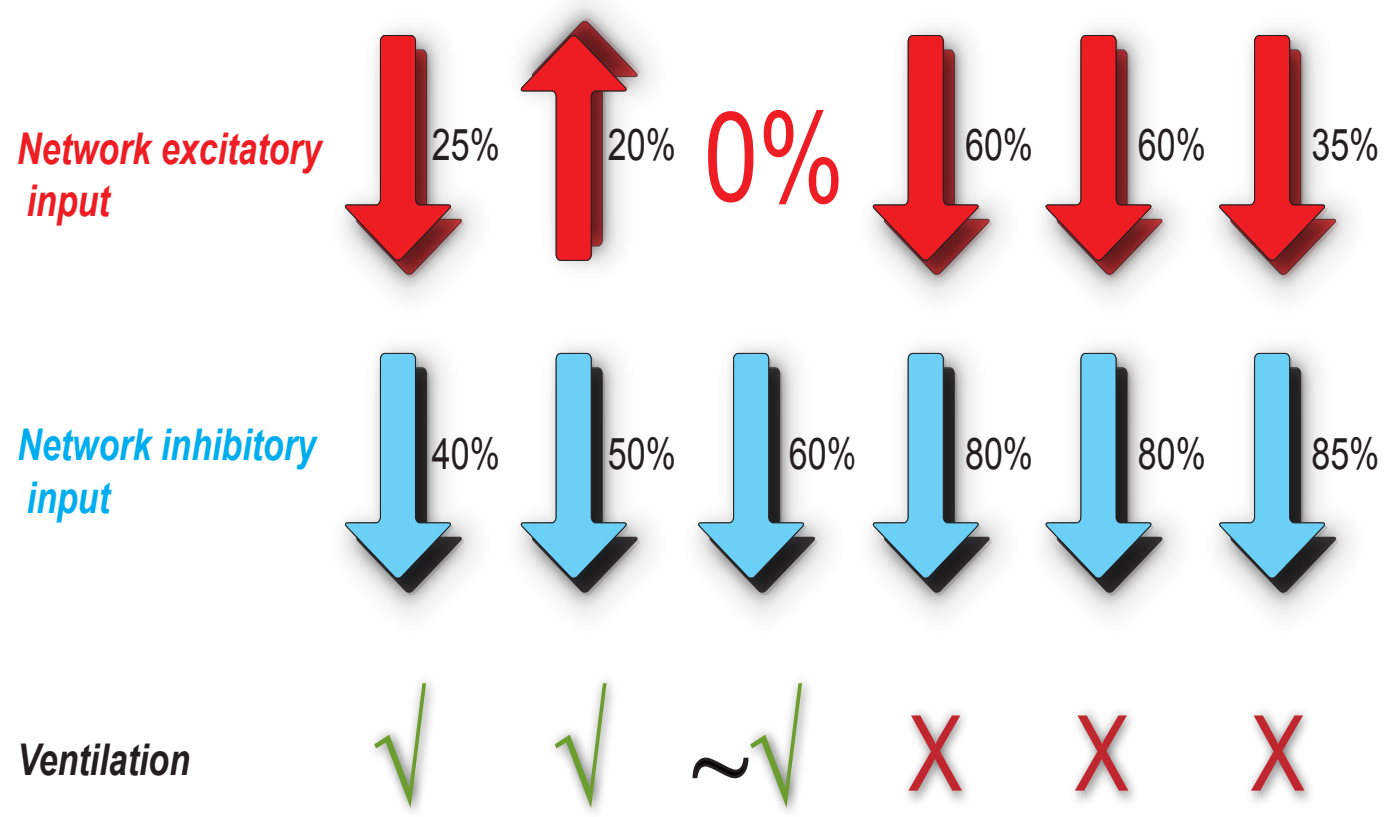

Figure 4.1 Inhibition in the brainstem respiratory network is essential for ventilation. The frequency of excitatory PSCs (red arrows) is less important than the frequency of inhibitory PSCs (blue arrows) in determining the outcome of ventilation function $(\sqrt{ }$ means normal ventilation; $\sim \sqrt{ }$ means normal ventilation, but irregular and $X$ means failure of ventilation)

RVLM in generating the respiratory rhythm (Richter and Spyer, 2001), this is most probable the underlying cause of failure in the respiratory rhythm generation and our comparison between different studied models support this notion (Fig. 4.1). Therefore, a moderate reduction of less than $50 \%$ of inhibitory network activity as reported in the present study of MeCP2-deficient mice and NL-1 KO mice is not expected to change resting ventilation activity but may have an effect on the adaptability of the respiratory network during stressful activities.

\subsubsection{Disinhibition and hyperexcitability in the brainstem respiratory network of MeCP2 KO mice}

Published data on impairments of synaptic transmission in MeCP2-deficient mice are controversial with respect to the components affected: in the hippocampus, loss of MeCP2 caused enhanced excitatory transmission (Moretti et al. 2006), and reduced paired-pulse facilitation and LTP (Asaka et al. 2006; Moretti et al. 2006), whereas Dani et al. (2005) showed that MeCP2 KO mice present a reduction of excitatory activity and an increase of spontaneous but not miniature IPSC in neocortical layer 5 neurons. Additionally, in hippocampal cultures from MeCP2 KO mice, the frequency 


\section{Discussions}

of miniature EPSCs is decreased (Nelson et al. 2006), with no effect on either the frequency and amplitude of mIPSCs (Nelson et al. 2006). Although the divergent results may reflect the different brain regions and ages investigated, these studies uniformly emphazised the general importance of the balance between inhibitory and excitatory synaptic transmission for the ethiology of RTT, and is confirmed by our current findings in the brainstem (Fig. 3.1-2). Our data in the respiratory medulla show that both evoked and spontaneous inhibitory synaptic transmission is reduced in the MeCP2 KO mice. Extending the previously published data, we now show that it is specifically the GABA- but not the glycine-mediated component of inhibitory synaptic transmission that is significantly compromised in MeCP2 mutants (Fig. 3.3$5)$.

On the other hand, the data about excitatory synaptic transmission in the present study are contradictory (Fig. 3-1-2; Fig 3.8). We have found that, although the strength of excitatory synapses is reduced (reduced mEPSC frequency and amplitude; Fig 3.8) in the hypoglossal nucleus, the network spontaneous and evoked excitatory activity in hypoglossal nucleus and RVLM is enhanced (Fig. 3-1-2; Fig 3.8). However, in the same MeCP2 KO line that we use, Zhang et. al.(2007) shows similar results in the adult hippocampus. Using whole-cell patch clamp and extracellular recordings, Zhang et. al. (2007) shows that the frequency of the IPSP-driven spontaneous rhythmic field potentials (SFRP) (extracellular) is reduced, along with the correlated IPSP (intracellular). Spontaneous glutamatergic activity in CA1 is reduced in the KO mice (Zhang et. al. 2007), however at high-frequency-stimulation (HFS), the system is prone to hyperexcitability. Chronic hyperexcitability, induced by a reduction in the frequency of spontaneous inhibitory PSCs in the functional maturation of the brainstem may be a possible explanation for our data. For example, induced chronic periods of hyperexcitability in different systems (Turrigiano et. al., 1998; O'Brien et al., 1998; Swann et. al., 2007) resulted in a dramatic decrease in the frequency and amplitude of mEPSC, as in our results. These changes may be due to intervention of activity-dependent homeostatic mechanisms (Turrigiano and Nelson, 2004), with the excitatory synapses trying to scale down their activity in order to maintain the proper excitatory/inhibitory balance. One other possible explanation for the difference between increase in the network excitatory PSCs and the decrease in the excitatory minis lies in the function of MeCP2 as a regulator of DNA methylation. Recently, it was shown that inhibitors of DNA methylation decrease the frequency of miniature excitatory PSC and this effect is mediated by MeCP2 (Nelson et. al., 2008). Moreover, the authors find that the effect of the DNA methylation inhibitors on mEPSCs overlaps with the effects induced by chronic hyperexcitability, suggesting a shared mechanism between the two in the control of spontaneous miniature 


\section{Discussions}

synaptic transmission (Nelson et. al., 2008).

\subsubsection{Specific reduction of the function of NMDA synapses underlies the network impairments in the NL-1 KO mice}

Deletion of Neuroligin 1, 2 and 3 leads to reductions in the activity of both inhibitory and excitatory synapses (Varoqueaux et. al., 2006), thus the study of individual knockouts can bring more information about the specific function of each isoform at each type of synapse. Consistent with the available results from the neuroligin field, our analysis of the NL-1 KO mice showed that the deletion of the protein affects mainly excitatory neurotransmission and has no effect on the inhibitory miniature synaptic transmission (Fig. 3.14-15). The decrease in the spontaneous inhibitory synaptic transmission is probably the result of reduced excitatory input in the network. In comparison, the study of NL-2 KO mice revealed that the inhibitory, but not excitatory synaptic transmission is reduced in the absence of NL-2 (Aramuni et. al., in review). Previous study in in vitro systems showed that overexpression of NL-1 specifically cluster postsynaptic components of excitatory synapses, leading to an increase in the frequency and amplitude of miniature excitatory currents (Chih et. al, 2005; Prange et. al., 2004). More specific, overexpression of NL-1 in hippocampal neurons primary cultures enhances both NMDA- and AMPA-evoked responses (Chubykin et. al., 2007). However, in the same study it was shown that deletion of NL-1 in mice induces a $\sim 50 \%$ reduction in the NMDA evoked response in hippocampal slice, with no change in the AMPA-mediated evoked response (Chubykin et. al., 2007). Our present study confirms that only the function of NMDAergic synapses is affected in the absence of NL-1 (Fig. 3.16). However, we notice a decrease in the frequency of miniature NMDA currents and, in opposition with Chubykin et. al. (2007) the amplitude of NMDA minis is increased. One possible explanation for this discrepancy lies in the faster decay time noticed by us in the NMDA minis from KO mice (Fig. 3.16, D, E). Faster decay times of NMDA currents are characteristic to the NMDA receptors that include NR2A subunits in their composition and NR2A subunits confers a higher amplitude to the NMDA receptor in which they are incorporated (Cull-Candy et. al., 2001; Vicini et. al., 1998; Monyer et. al., 1994), Thus, if this is the case, that may explain the discrepancies between our data and the results of Chubykin et. al. (2007). Moreover, NR2A subunits affect more the miniature currents than the evoked ones, as shown by the deletion of NR2A in mice (Townsend et.al., 2003). This may explain the difference in amplitude between our results and Chubykin et. al. (2007), as well as the difference between our increased miniature NMDA amplitude and the 


\section{Discussions}

significantly decreased amplitude of the evoked excitatory PSCs (Fig. 3.15).

\subsubsection{Loss of Nbea disrupts the function of inhibitory synapses leading to network failure}

First experimental evidence about the function of $\mathrm{Nbea}$ has been shown in a null mutant mouse line obtained by coincidental insertion mutagenesis. There, homozygous Nbea (-/-) mice were found to die immediately after birth, and displayed a complete block of evoked transmission at the neuromuscular junction (NMJ) whereas nerve conduction, NMJ morphology and spontaneous quantal release were normal (Su et al., 2004). The present study reveals that Nbea-KO mice suffer from apnea attributable to a severe impairment of excitatory and especially inhibitory synaptic transmission in brainstem respiratory network. The activity of both excitatory and especially inhibitory synapses is almost abolished. Regarding the functional role of Nbea, both the previous study (Su et al., 2004) and the current results point to a strong involvement of Nbea in synaptic function. Nevertheless, there are several discrepancies between the functional role of $\mathrm{Nbea}$ in the peripheral and central nervous system that might be very crucial for understanding the mechanisms of Nbea function. In the neuromuscular junction axons of motoneurons are able to form synapses that exhibit normal spontaneous AP-independent neurotransmitter release (mepps) but is unable to sustain evoked AP-dependent responses at the same synapse in Nbea-null mice (Su et al., 2004). In the present study, both APdependent (evoked and spontaneous) and AP-independent (miniature) synaptic transmissions are severely impaired in brainstem respiratory network (Fig. 3.20-22). One possible explanation of these discrepancies may lie in the differences in the functional assembly between CNS and NMJ synapses, as shown by other studies of proteins essential for synaptic transmission. In the Munc-13-1/2-DKO mice evoked and spontaneous synaptic transmission in hippocampus is entirely abolished (Varoqueaux et al., 2002) while at NMJ both are reduced but still present (Varoqueaux et al., 2005). SNAP-25 mutant mice present increased spontaneous transmission at the NMJ (Washbourne et al., 2002) and almost abolished spontaneous transmission in cortical slices (Tafoya et al., 2006), with the evoked neurotransmission being abolished at both synapses. One the other hand, the rich expression of Nbea in the CNS as compared with the muscle (Su et al., 2004), along with morphological and biochemical synaptic changes (see 4.2.3) suggest that the protein plays an essential role in the formation of central synapses, while at the NMJ other proteins may compensate its function. 
Discussions

\subsection{Specific impairments in synaptic maturation underlie the network imbalance in mice models of ASD}

\subsubsection{Both pre- and postsynaptic components of inhibitory and excitatory synapses are affected in the absence of MeCP2}

\subsubsection{Excitatory and inhibitory synaptic density is reduced in the absence of $\mathrm{MeCP} 2$}

The reduced frequency of GABAergic synaptic transmission in MeCP2 KO mice is due to a reduction of specific presynaptic (Fig. 3.4) components. Our findings of reduced punctae of VIAAT in the RVLM of MeCP2 mutant mice suggest a role for MeCP2 in the regulation of genes important for the formation, function and maintenance of inhibitory synapses. This is the first time when a reduction in the number of inhibitory synaptic markers is shown in the MeCP2 KO mice. Our current results are consistent with the demonstration that BDNF is a target of MeCP2 transcriptional repression (Chang et al. 2006) because BDNF promotes GABAergic synaptogenesis (Carrasco et al. 2007; Marty et al. 2000; Yamada et al. 2002), and the BDNF receptors appear to be abundant in the ventrolateral medulla of neonatal mice (Thoby-Brisson et al. 2003). Moreover, we measured the expression of the excitatory synaptic markers VGLUT (1 and 2) in the hypoglossal nucleus and we found a reduction in the number of VGLUT punctae in the MeCP2 KO mice (Fig. 3.9). This may explain the reduction in the excitatory mini frequency described above (Fig. 3.8). These data are inline with recently published data that MeCP2 might play a key role in regulating glutamatergic synapse formation in early postnatal development (Chao et al. 2007).

\subsubsection{Postsynaptic developmental maturation is impaired in the MeCP2 KO mice}

The maturation of GABA synapses depends upon switches of distinct subunits of many receptor and channel classes, e.g., in the thalamus and cortex of rats the $\mathrm{GABA}_{\mathrm{A}}$ receptor subunits undergo a change from $\alpha 2$ (or $\alpha 3$ ) to $\alpha 1$ during postnatal development (Bosman et al. 2002; Fritschy et al. 1994). Here, we found that in MeCP2-deficient mice, the expression of the $\alpha 2$ subunit of $\mathrm{GABA}_{\mathrm{A}}$ receptors in the ventrolateral medulla was significantly decreased, as shown independently by immunoblotting and quantitative RT-PCR experiments (Medrihan et. al, 2008). As GABA $_{A}$ receptors generally consist of two $\alpha$, two $\beta$ and one $\gamma$ subunits (Baumann et al. 2001; Farrant and Nusser 2005), the $\alpha 2$ subunit is very abundant in early postnatal ages in many brain regions (Laurie et al. 1992; Liu and Wong-Riley 2004) and is subsequently downregulated in the adult. However, in regions like 


\section{Discussions}

hippocampus, neocortex or midbrain, postnatal $\alpha 2$ expression does not decrease and is maintained at the same level in adult life (Laurie et al. 1992; Liu and WongRiley 2004). Interestingly, changes in $\mathrm{GABA}_{\mathrm{A}}$ receptor subunit composition can be correlated with an alteration of binding kinetics and allosteric properties of the $\mathrm{GABA}_{A}$ receptor (Okada et al. 2000). The decrease in the expression of $\mathrm{GABA}_{A} \alpha 2$ subunit observed in our study (Fig. 3.7) could explain the changes in the decay time of mGPSCs (Fig. 3.3), whereas the alternative explanation of a changed expression of $\mathrm{GABA}_{A} \alpha 1$ subunit was not validated (Fig. 3.6-7). Our results on altered $\mathrm{GABA}_{A}$ receptor composition in MeCP2 knockout mice are consistent with decreased benzodiazepine receptor binding in brains of RTT patients (Yamashita et al. 1998). However, another recent study reported a downregulation in the $\mathrm{GABA}_{\mathrm{A}} \beta 3$ subunit expression levels in both RTT patients and two strains of MeCP2 deficient mice (Samaco et al. 2005) which was not altered in our study. Our observation of a changed expression of the $\alpha 2$ subunit of the $\mathrm{GABA}_{\mathrm{A}}$ receptor in MeCP2 KO mice may be relevant to symptoms in RTT patients: the $\alpha 2$ containing GABA receptors are expressed in synapses located mainly on axon initial segment (Brunig et al. 2002; Cruz et al. 2003) of the reticular activating system, limbic system, amygdala and hippocampus (Rudolph and Mohler 2004), where it mediates the anxiolytic action of benzodiazepines (Low et al. 2000). These data suggest that $\alpha 2$ containing GABA receptors are crucially involved in processing of emotional stimuli (Rudolph and Mohler 2004), and its downregulation as reported here could provide an explanation of the autism-like symptoms of Rett syndrome patients.

The maturation of the glutamatergic synapses is a long-term process involving changes in both the ultrastructure and the electrophysiologichal properties (McAllister, 2007). One of the main characteristics at the postsynaptic site is the developmental switch to receptor subunits that speed the synaptic transmission in mature synapses (Cull-Candy et. al., 2001; Takahashi, 2005). At NMDA receptors, a developmental switch between the slow decay NR2B subunit and the fast decay NR2A subunit takes place (Cull-Candy et. al., 2001; Takahashi, 2005; Monyer et. al., 1994; Vicini et. al., 1998). In the MeCP2 KO mice we noticed a decrease in the expression levels of the NR2A subunit (Fig. 3.10), underlying the slower kinetics noticed in the excitatory minis (Fig. 3.8). These results suggest the importance of MeCP2 in the developmental maturation of the synapses: like $G_{A B A} \alpha 2, N R 2 A$ is also a subunit whose incorporation in synapses is developmentally regulated (CullCandy et. al., 2001; Takahashi, 2005). The importance of this process is increased by the fact that mutations in GRIN2A, the gene that encodes the NR2A subunit showed high significant association with ASDs, (Persico and Bourgeron, 2006). Our results show also an increase in the GluR1 subunit of postsynaptic AMPA receptors 


\section{Discussions}

(Fig 3.10). An increased expression of GluR1 should result in faster decay times and higher amplitudes (Takahashi, 2005), which is not the case in our experiments (Fig. 3.8) Since GluR1 receptors are weakly expressed in the hypoglossal nucleus but strongly expressed in the inferior olive (Paarman et. al., 2000) it may be that these discrepancies are due to different regional expression of the subunit.

\subsubsection{Deletion of NL-1 leads to impairments in the maturation of NMDAergic synapses}

The $\sim 50 \%$ reduction in the frequency of NMDA minis (Fig. 3.15-16) may be the result of a similar reduction in the density of NMDA synapses. Previous studies have correlated changes in expression of NL-1 in culture systems with changes in the density of excitatory synapses (Dean et. al., 2003; Chih et. al., 2005; Levinson et al., 2005). Our study is still at a preliminary stage, so we do not know if a reduction in the number of NMDAergic synapses is the cause of the changes in frequency noticed. However, since in the NL TKO the density of excitatory synapses is not affected (Varoqueaux et. al., 2006) we do not presume that this is the case.

NMDA receptors play critical roles in the plasticity and excitotoxicity of the CNS. As described above (see 4.2.1.2), they are tetramers composed of two NR1 subunits and two different NR2 (from A to D) subunits (Cull-Candy et. al., 2001). The identity of the NR2 subunit influences, among other properties, the time course of the excitatory PSCs(Cull-Candy et. al., 2001; Vicini et. al., 1998). Our observation of a faster decay time of NMDA miniature currents lead us to speculate of a change in the subunit composition of NMDA receptors in the NL-1 mutant mice. Compared with results from Paarman et. al. (2000) and O'Brien et. al., (1997) we find that the decay time of our NMDA minis in the WT mice from NH is comparable to those obtained by them in the same nucleus at a aproximatively similar age (second postnatal week) ( $32 \mathrm{~ms}$ for our study (Table 3.3); $38 \mathrm{~ms}$ for Paarman et. al. (2000) and 42 ms for O'Brien et. al. (1997)). In another study, Paarman et. al. (2005) shows that in the NH the NR2A, NR2B and NR2D subunits are highly expressed. Based on these data we can explain the faster decay time by either an enrichment in the expression of NR2A subunits since the decay times of NR2A are the fastest: NR2A $<$ NR2B $<<$ NR2C (Cull-Candy et. al., 2001). Since the interaction of NL-1 with PSD95 has been extensively characterized (Irie et al., 1997; Prange et. al., 2004) and PSD-95 is responsible for bringing the NR2A subunits at the synapse (Sans et. al., 2000) we may speculate that NL-1 plays a role in the postsynaptic maturation of NMDA synapses. In line with this hypothesis, experiments from NLTKO mice or NL-2 KO mice showed that the expression of specific subunits of GABA receptors is reduced in the KOs (Varoqueaux et. al., 2006; Aramuni et. al., in review). Thus, 


\section{Discussions}

different members of the Neuroligin family may control the glutamatergic/GABAergic postsynaptic differentiation and by this the excitatory/inhibitory network balance.

\subsubsection{Nbea is essential for the formation of central synapses}

Despite the complete absence of evoked synaptic transmission in NMJ, the number, the structure and the maturation of neuromuscular synapses appear normal in Nbea-null mice (Su et al., 2004). Our analysis of the distribution and ultrastructure of brainstem synapses reveals a reduction of both synaptic density and the number of synaptic vesicles per presynaptic terminals in brainstem RVLM of Nbea-KO mice (Fig. 4.2). The reduced number of synapses could at least partly explain the reduced frequency of miniature EPSC and IPSC (Fig. 3.20-21) in the brainstem synapses of Nbea-KO mice. Thus, our data provide evidence that Nbea is required for formation and functional assembly of central synapses, but is not essential for NMJ.

Taken together, the electrophysiological and morphological data presented sofar point to a strong presynaptic phenotype. Indeed, our analysis of the presynaptic markers revealed that several key protein of the presynaptic machinery, such as synaptophysin, SV2, Mint-1, are downregulated in the Nbea KO mice (Fig. 3.23). Synaptophysin $1 \mathrm{KO}$ has been shown to be not essential for neurotransmitter release (McMahon et al., 1996), while SV2A/SV2B are essential for Ca2+-dependent release (Janz et al., 1999). On the other hand, synapsin-TKO causes decrease of inhibitory synaptic transmission decreased (Gitler et al., 2004), whereas Mint1-KO

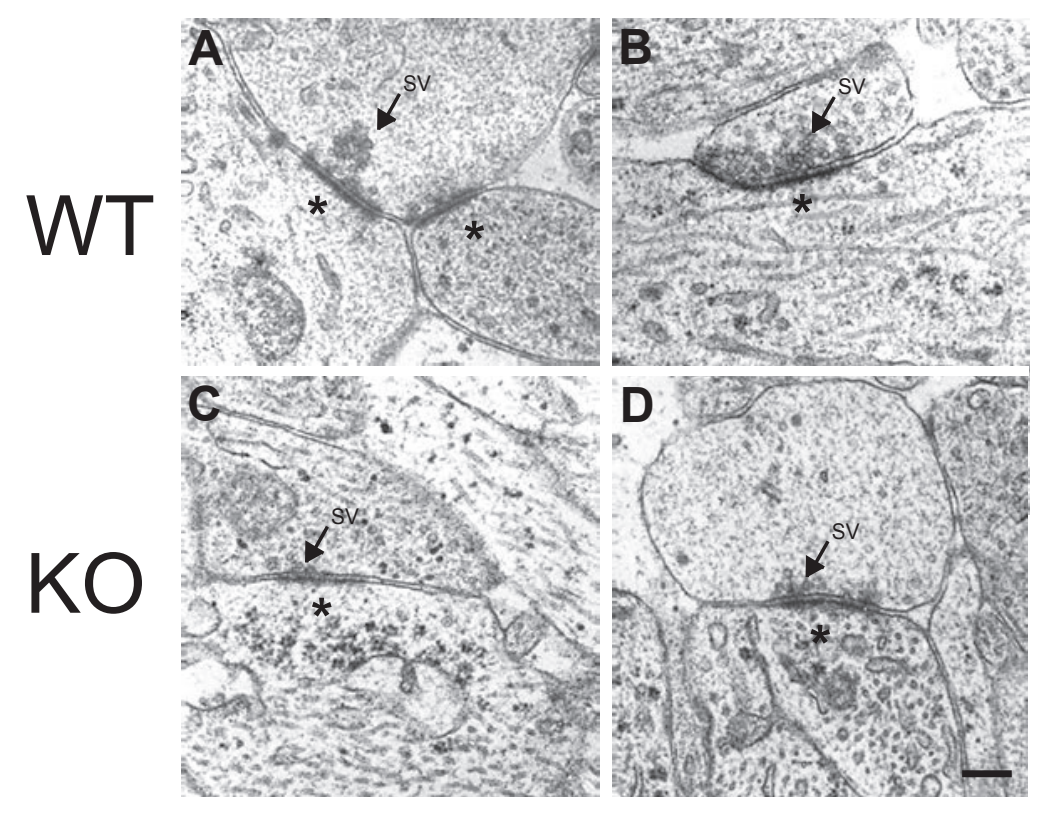

Figure 4.2 Ultrastructure of synapses is affected in the neurobeachin-deficient mice. $(A-D)$ Electron micrographs of representative synapses (asterisks) in the ventral rostral medulla of littermate control $(A, B)$ and knockout animals $(C, D)$. Presynaptic terminals of mutant mice contain synaptic vesicles (SV, arrows). Scale bar, $0.2 \mu \mathrm{m}$ 


\section{Discussions}

impairs GABAergic inhibitory synaptic transmission (Ho et al., 2003). But, despite their involvement in presynaptic exocytosis the complete lost the above presynaptic proteins does only moderately impair synaptic functions and almost all the nullmutant mice are viable, except for the SV2A/SV2B DKO (McMahon et al., 1996; Janz et al., 1999; Gitler et al., 2004; Ho et al., 2003). Therefore, a moderate reduction of presynaptic proteins as shown in the present study (Fig. 3.23) cannot be the primary cause of the lethal phenotype of Nbea-null mice. These data, thus, suggest that Nbea the reduced of presynaptic proteins, might be the consequence of reduced number of synapses or the reduced number of vesicles noticed in the brainstem of Nbea KO mice (Fig. 4.2), but not the primary cause for the phenotype.

In the present study the amplitude of spontaneous IPSCs is significantly reduced in Nbea-KO mice. Nbea-KO also reveals a tendency of reduced decay time in mIPSC and mEPSC (Table 3.4). In addition the amount of postsynaptic NMDA-Receptor was significantly reduced in brainstem homogenates of Nbea-KO mice. Thus, these data point to an additional postsynaptic phenotype, even not in the same extent as the presynaptic phenotype of Nbea-KO mice. These findings also differ from the previous finding that the function of postsynaptic AchR is normal in NMJ of Nbeanull mice and the absence of evoked epps could not be explained by disruption of postsynaptic function (Su et al., 2004). One possible explanation of this discrepancy is that the postsynapses of NMJ are not neuronal where Nbea does not play a functional role in the postsynaptic assembly in NMJ.

\subsection{General discussions}

Unlike brain diseases caused by sudden lesions, the clinical symptoms of developmental disorders result from complex interactions among many brain regions, networks, and proteins. We show here that the maintenance of a proper balance between excitation and inhibition in a neural network is a delicate process that starts early in development. Furthermore, we show that changes in both the maturation and the function of inhibitory and/or excitatory synapses underlie the network imbalance and further the output function of the network.

The resting ventilation is normal in the MeCP2 and NL-1 mice and is absent in the Nbea KO mice. Since respiratory network is a highly modulated and compensated network (Feldman and Del Negro 2006; Richter and Spyer 2001) we show that more than $\sim 50 \%$ reductions in network inhibitory activity are necessary to produce visible changes in the ventilation (Fig. 4.1).

An early imbalance in the network activity underlied by changes in synaptic function is noticed in all our mice models. In all the mice analysed we see a reduction in inhibition, produced either by direct reduction in the function of inhibitory synapses, 


\section{Discussions}

as it it the case for Nbea KO mice, or even more specific, by direct reduction in the function of GABAergic synapses, as it results from the deletion of MeCP2. As for the $\mathrm{NL}-1 \mathrm{KO}$ mice, the reduction in inhibition is probably an indirect effect induced by the reduction in excitation, since at this age both GABA and glycine are excitatory due to the depolarizing $\mathrm{Cl}^{-}$reversal potential (Ben-Ari et al., 2004). The reduced excitation in the NL-1 KO mice is underlied by a specific reduction in the function of NMDAergic synapses and in the case of $\mathrm{Nbea}$, by a general reduction of the function of excitatory synapses. In the absence of MeCP2 it was surprising to notice that the network is prone to hyperexcitability, although the function of excitatory synapses is reduced. Our interpretation of this data is that the network is trying to balance the loss-of-function at synaptic level by homeostatic mechanism (Nelson et. al., 2008). It may be possible in the case of MeCP2 KO mice that this imbalance may eventually lead to the apparition of the later severe phenotype of these mice, at an age when the modulatory systems can not counterbalance anymore this lossof-function.

In the mice models we analysed we notice structural changes at the synaptic level that may represent the underlying cause of the described functional imbalance. In the absence of MeCP2 the density of both excitatory and inhibitory synapses is reduced, strengthening the synaptogenic role that was proposed for this transcriptional repressor (Zoghbi, 2003). A reduction in the density of synapses is a dramatic effect especially starting at such an early stage of the development, when the network is barely formed, and it may lead to severe impairments in its future development. In the absence of Nbea not only the density, but also the presynaptic organization of inhibitory and excitatory synapses is severely altered, suggesting an important role for this protein in the formation of synapses. Indeed, the function of the Nbea KO synapses is almost abolished, leading to respiratory failure, paralysis and immediate death. Due to such effects Nbea KO mice are not suitable mice models for ASDs since it is obvious that in autistic patients such a loss-of-function is not present. It may be the case that point mutations in the gene, as the one noticed in patients (Castermans et. al., 2003), may lead to a milder effect, with the protein partially maintaining its function.

One interesting aspect noticed in the analysed mice is the loss of specific postsynaptic receptor subunits, such as $\mathrm{GABA}_{A} \alpha 2$ or NMDAR2A. These subunits are normally under strict developmental regulation, and their incorporation in the respective receptors at specific developmental times gives specific kinetic properties (Takahashi, 2005; Cull-Candy et. al., 2001; Farrant and Nusser, 2005) and their absence may lead to temporal network imbalance, disabling the capacity of the network to react to activity-dependent changes. The downregulation of these subunits in the MeCP2 


\section{Discussions}

$\mathrm{KO}$ mice and probably in the $\mathrm{NL}-1 \mathrm{KO}$ mice suggest that these proteins play also an important role in maintaining the temporal network imbalance.

In conclusion, each of the protein analysed plays an important role in the function and maturation of the synapses and their absence leads to spatio-temporal network imbalance. Their adjacent association with autistic spectrum disorders suggest that these neurodevelopmental disorders may have an earlier cellular onset than it is believed. It may be possible that these early network imbalance, barely noticeable in the unstressful life of an infant may manifest itself when the environmental factors and/or the multitude of sensorial stimuli subject the network to adaptive stress. Since early diagnostics are essential in the treatment of ASDs we can only hope that our present work may bring a little more knowledge to the few we have about the onset of these terrible disorders. 


\section{Summary}

Maintaining a proper balance between excitation and inhibition is a key feature of neural networks. Autistic spectrum disorders (ADSs) have been proposed to result from an excitatory/inhibitory network imbalance caused by synaptic impairments. Mice models in which selected candidate genes are mutated were generated and the behavioural phenotype of these mice presented strong similarities with the symptoms of human patients. However, the developmental onset of these symptoms is still largely unknown.

Here, we analysed three mice models in which genes that cause special forms of ASDs (MeCP2), belong to a family responsible for many cases of ASDs (NLGN-1) or their mutations induce cases of idiopathic ASD (NBEA) have been knocked-out. Since all of these proteins are presumably involved in formation and maturation, we investigated the functional and structural synaptic and subsequent network changes caused by their absence in the first postnatal week. We used the brainstem respiratory network as an experimental model, since this network is functional immediately after birth.

Our results show that the deletion of these proteins in mice leads to specific alterations in the function and the maturation of the synapses starting from an earl developmental stage. The deletion of MeCP2 results in a decreased density of both inhibitory and excitatory synapses and in the reduced expression of developmentally important GABA and NMDA postsynaptic receptor subunits. The absence of NL-1 leads to reduced function of NMDAergic synapses, while the Nbea KO mice present severe alterations in the formation and function of both excitatory and inhibitory synapses. These synaptic impairments are translated in imbalance in the overall network inhibition and excitation, and the severity of this imbalance is correlated with the ability of the neural network to perform its output function, in our case respiration.

From our data we hypothesise that early developmental synaptic changes in the genetic mice models of ASDs may lead to the loss of experience-dependent synaptic plasticity noticed in these mice models and to their behavioural symptoms. 


\section{References}

\section{References}

Akerman CJ \& Cline HT. (2007). Refining the roles of GABAergic signaling during neural circuit formation. Trends Neurosci 30, 382-389.

American Psychiatric Association. Task Force on DSM-IV. Diagnostic and Statistical Manual of Mental Disorders: DSM-IV-TR. 4th ed. Washington, DC: American Psychiatric Association; 2000

Amir RE, Van den Veyver IB, Wan M, Tran CQ, Francke U \& Zoghbi HY. (1999). Rett syndrome is caused by mutations in X-linked MECP2, encoding methyl-CpGbinding protein 2. Nat Genet 23, 185-188.

Angleson JK \& Betz WJ. (2001). Intraterminal $\mathrm{Ca}(2+)$ and spontaneous transmitter release at the frog neuromuscular junction. J Neurophysiol 85, 287-294.

Aramuni G., Varoqueaux F., Poulopoulos A., Brose N. \& Zhang W. Neuroligin 2 determines the maturation and function of GABAergic and glycinergic synapses. J.Neuroscience. In review.

Armstrong DD. (2005). Can we relate MeCP2 deficiency to the structural and chemical abnormalities in the Rett brain? Brain Dev 27 Suppl 1, S72-S76.

Asaka Y, Jugloff DG, Zhang L, Eubanks JH \& Fitzsimonds RM. (2006). Hippocampal synaptic plasticity is impaired in the Mecp2-null mouse model of Rett syndrome. Neurobiol Dis 21, 217-227.

Bailey A, Le Couteur A, Gottesman I, Bolton P, Simonoff E, Yuzda E \& Rutter M. (1995). Autism as a strongly genetic disorder: evidence from a British twin study. Psychol Med 25, 63-77.

Balmer D, Goldstine J, Rao YM \& LaSalle JM. (2003). Elevated methyl-CpG-binding protein 2 expression is acquired during postnatal human brain development and is correlated with alternative polyadenylation. J Mol Med 81, 61-68.

Banks MI, Hardie JB \& Pearce RA. (2002). Development of GABA(A) receptormediated inhibitory postsynaptic currents in hippocampus. J Neurophysiol 88, 30973107. 
References

Barrett S, Beck JC, Bernier R, Bisson E, Braun TA, Casavant TL, Childress D, Folstein SE, Garcia M, Gardiner MB, Gilman S, Haines JL, Hopkins K, Landa R, Meyer NH, Mullane JA, Nishimura DY, Palmer P, Piven J, Purdy J, Santangelo SL, Searby C, Sheffield V, Singleton J, Slager S \& et al. (1999). An autosomal genomic screen for autism. Collaborative linkage study of autism. Am J Med Genet 88, 609615.

Baumann SW, BaurR \& SigelE. (2001). Subunit arrangement of gamma-aminobutyric acid type A receptors. J Biol Chem 276, 36275-36280.

Beaulieu C, Campistron G \& Crevier C. (1994). Quantitative aspects of the GABA circuitry in the primary visual cortex of the adult rat. J Comp Neurol 339, 559-572.

Belmonte MK \& Bourgeron T. (2006). Fragile X syndrome and autism at the intersection of genetic and neural networks. Nat Neurosci 9, 1221-1225.

Ben-Ari Y, Khalilov I, Represa A \& Gozlan H. (2004). Interneurons set the tune of developing networks. Trends Neurosci 27, 422-427.

Blue ME, Naidu S \& Johnston MV. (1999). Altered development of glutamate and GABA receptors in the basal ganglia of girls with Rett syndrome. Exp Neurol 156, 345-352.

Bolton P, Macdonald H, Pickles A, Rios P, Goode S, Crowson M, Bailey A \& Rutter M. (1994). A case-control family history study of autism. J Child Psychol Psychiatry 35, 877-900.

Bosman LW, Heinen K, Spijker S \& Brussaard AB. (2005). Mice lacking the major adult GABAA receptor subtype have normal number of synapses, but retain juvenile IPSC kinetics until adulthood. J Neurophysiol 94, 338-346.

Bosman LW, Rosahl TW \& Brussaard AB. (2002). Neonatal development of the rat visual cortex: synaptic function of GABAA receptor alpha subunits. J Physiol 545, 169-181.

Boucard AA, Chubykin AA, Comoletti D, Taylor P \& Sudhof TC. (2005). A splice code for trans-synaptic cell adhesion mediated by binding of neuroligin 1 to alpha- and beta-neurexins. Neuron 48, 229-236. 
References

Brunig I, Scotti E, Sidler C \& Fritschy JM. (2002). Intact sorting, targeting, and clustering of gamma-aminobutyric acid A receptor subtypes in hippocampal neurons in vitro. J Comp Neurol 443, 43-55.

Carrasco MA, Castro P, Sepulveda FJ, Tapia JC, Gatica K, Davis MI \& Aguayo LG. (2007). Regulation of glycinergic and GABAergic synaptogenesis by brain-derived neurotrophic factor in developing spinal neurons. Neuroscience 145, 484-494.

Castermans D, Wilquet V, Parthoens E, Huysmans C, Steyaert J, Swinnen L, Fryns JP, Van de Ven W \& Devriendt K. (2003). The neurobeachin gene is disrupted by a translocation in a patient with idiopathic autism. J Med Genet 40, 352-356.

Chahrour M \& Zoghbi HY. (2007). The story of Rett syndrome: from clinic to neurobiology. Neuron 56, 422-437.

Chao HT, Zoghbi HY \& Rosenmund C. (2007). MeCP2 Controls Excitatory Synaptic Strength by Regulating Glutamatergic Synapse Number. Neuron 56, 58-65.

Chen RZ, Akbarian S, Tudor M \& Jaenisch R. (2001). Deficiency of methyl-CpG binding protein-2 in CNS neurons results in a Rett-like phenotype in mice. Nat Genet 27, 327-331.

Chen WG, Chang Q, Lin Y, Meissner A, WestAE, Griffith EC, Jaenisch R \& Greenberg ME. (2003). Derepression of BDNF transcription involves calcium-dependent phosphorylation of MeCP2. Science 302, 885-889.

Chih B, Gollan L \& Scheiffele P. (2006). Alternative splicing controls selective transsynaptic interactions of the neuroligin-neurexin complex. Neuron 51, 171-178.

Christodoulou J \& Weaving LS. (2003). MECP2 and beyond: phenotype-genotype correlations in Rett syndrome. J Child Neurol 18, 669-674.

Chubykin AA, Atasoy D, Etherton MR, Brose N, Kavalali ET, Gibson JR \& Sudhof TC. (2007). Activity-dependent validation of excitatory versus inhibitory synapses by neuroligin-1 versus neuroligin-2. Neuron 54, 919-931.

Collins AL, Levenson JM, Vilaythong AP, Richman R, Armstrong DL, Noebels JL, David Sweatt J \& Zoghbi HY. (2004). Mild overexpression of MeCP2 causes a 
progressive neurological disorder in mice. Hum Mol Genet 13, 2679-2689.

Craig AM \& Kang Y. (2007). Neurexin-neuroligin signaling in synapse development. Curr Opin Neurobiol 17, 43-52.

Cruz DA, Eggan SM \& Lewis DA. (2003). Postnatal development of pre- and postsynaptic GABA markers at chandelier cell connections with pyramidal neurons in monkey prefrontal cortex. J Comp Neurol 465, 385-400.

Cull-Candy S, Brickley S \& Farrant M. (2001). NMDA receptor subunits: diversity, development and disease. Curr Opin Neurobiol 11, 327-335.

Dani VS, Chang Q, Maffei A, Turrigiano GG, Jaenisch R \& Nelson SB. (2005). Reduced cortical activity due to a shift in the balance between excitation and inhibition in a mouse model of Rett syndrome. Proc Natl Acad Sci U S A 102, 12560-12565.

De Felipe J, Marco P, Fairen A \& Jones EG. (1997). Inhibitory synaptogenesis in mouse somatosensory cortex. Cereb Cortex 7, 619-634.

Dean C, Scholl FG, Choih J, DeMaria S, Berger J, Isacoff E \& Scheiffele P. (2003). Neurexin mediates the assembly of presynaptic terminals. Nat Neurosci $6,708-$ 716.

DiCicco-Bloom E, Lord C, Zwaigenbaum L, Courchesne E, Dager SR, Schmitz C, Schultz RT, Crawley J \& Young LJ. (2006). The developmental neurobiology of autism spectrum disorder. J Neurosci 26, 6897-6906.

Durand CM, Betancur C, Boeckers TM, Bockmann J, Chaste P, Fauchereau F, Nygren G, Rastam M, Gillberg IC, Anckarsater H, Sponheim E, Goubran-Botros H, Delorme R, Chabane N, Mouren-Simeoni MC, de Mas P, Bieth E, Roge B, Heron D, Burglen L, Gillberg C, Leboyer M \& Bourgeron T. (2007). Mutations in the gene encoding the synaptic scaffolding protein SHANK3 are associated with autism spectrum disorders. Nat Genet 39, 25-27.

Einspieler C, Kerr AM \& Prechtl HF. (2005a). Abnormal general movements in girls with Rett disorder: the first four months of life. Brain Dev 27 Suppl 1, S8-S13.

Einspieler C, Kerr AM \& Prechtl HF. (2005b). Is the early development of girls with 


\section{References}

Rett disorder really normal? Pediatr Res 57, 696-700.

Farrant M \& Nusser Z. (2005). Variations on an inhibitory theme: phasic and tonic activation of GABA(A) receptors. Nat Rev Neurosci 6, 215-229.

Feldman JL \& Del Negro CA. (2006). Looking for inspiration: new perspectives on respiratory rhythm. Nat Rev Neurosci 7, 232-242.

Folstein S \& Rutter M. (1977). Genetic influences and infantile autism. Nature 265, 726-728.

Frerking M, Borges S \& Wilson M. (1997). Are some minis multiquantal? J Neurophysiol 78, 1293-1304.

Fritschy JM, Paysan J, Enna A \& Mohler H. (1994). Switch in the expression of rat GABAA-receptor subtypes during postnatal development: an immunohistochemical study. J Neurosci 14, 5302-5324.

Fukuda T, Itoh M, Ichikawa T, Washiyama K \& Goto Y. (2005). Delayed maturation of neuronal architecture and synaptogenesis in cerebral cortex of Mecp2-deficient mice. J Neuropathol Exp Neurol 64, 537-544.

Futai K, Okada M, Matsuyama K \& Takahashi T. (2001). High-fidelity transmission acquired via a developmental decrease in NMDA receptor expression at an auditory synapse. J Neurosci 21, 3342-3349.

Gitler D, Takagishi Y, Feng J, Ren Y, Rodriguiz RM, Wetsel WC, Greengard P \& Augustine GJ. (2004). Different presynaptic roles of synapsins at excitatory and inhibitory synapses. J Neurosci 24, 11368-11380.

Guy J, Gan J, Selfridge J, Cobb S \& Bird A. (2007). Reversal of neurological defects in a mouse model of Rett syndrome. Science 315, 1143-1147.

Guy J, Hendrich B, Holmes M, Martin JE \& Bird A. (2001). A mouse Mecp2-null mutation causes neurological symptoms that mimic Rett syndrome. Nat Genet 27 , 322-326.

Hagberg B, Aicardi J, Dias K \& Ramos O. (1983). A progressive syndrome of autism, 
References

dementia, ataxia, and loss of purposeful hand use in girls: Rett's syndrome: report of 35 cases. Ann Neurol 14, 471-479.

Hanefeld F, Hanefeld U, Wilichowski E \& Schmidtke J. (1986). Rett syndrome-search for genetic markers. Am J Med Genet Suppl 1, 377-382.

Ho A, Morishita W, Hammer RE, Malenka RC \& Sudhof TC. (2003). A role for Mints in transmitter release: Mint 1 knockout mice exhibit impaired GABAergic synaptic transmission. Proc Natl Acad Sci U S A 100, 1409-1414.

Horike S, Cai S, Miyano M, Cheng JF \& Kohwi-Shigematsu T. (2005). Loss of silentchromatin looping and impaired imprinting of DLX5 in Rett syndrome. Nat Genet 37, 31-40.

Ichtchenko K, Hata Y, Nguyen T, Ullich B, Missler M, Moomaw C \& Sudhof TC. (1995). Neuroligin 1: a splice site-specific ligand for beta-neurexins. Cell 81, 435443.

Ide S, Itoh M \& Goto Y. (2005). Defect in normal developmental increase of the brain biogenic amine concentrations in the mecp2-null mouse. Neurosci Lett 386, 14-17.

Irie M, Hata Y, Takeuchi M, Ichtchenko K, Toyoda A, Hirao K, Takai Y, Rosahl TW \& Sudhof TC. (1997). Binding of neuroligins to PSD-95. Science 277, 1511-1515.

Jamain S, Quach H, Betancur C, Rastam M, Colineaux C, Gillberg IC, Soderstrom H, Giros B, Leboyer M, Gillberg C \& Bourgeron T. (2003). Mutations of the X-linked genes encoding neuroligins NLGN3 and NLGN4 are associated with autism. Nat Genet 34, 27-29.

Jamain S, Radyushkin K, Hammerschmidt K, Granon S, Boretius S, Varoqueaux F, Ramanantsoa N, Gallego J, Ronnenberg A, Winter D, Frahm J, Fischer J, Bourgeron T, Ehrenreich H \& Brose N. (2008). Reduced social interaction and ultrasonic communication in a mouse model of monogenic heritable autism. Proc Natl Acad Sci U S A 105, 1710-1715.

Janz R, Goda Y, Geppert M, Missler M \& Sudhof TC. (1999). SV2A and SV2B function as redundant $\mathrm{Ca} 2+$ regulators in neurotransmitter release. Neuron 24, 1003-1016.

Jian L, Nagarajan L, de Klerk N, Ravine D, Bower C, Anderson A, Williamson S, 
References

Christodoulou J \& Leonard H. (2006). Predictors of seizure onset in Rett syndrome. J Pediatr 149, 542-547.

Johnston MV, Jeon OH, Pevsner J, Blue ME \& Naidu S. (2001). Neurobiology of Rett syndrome: a genetic disorder of synapse development. Brain Dev 23 Suppl 1, S206-213.

Johnston MV, Mullaney B \& Blue ME. (2003). Neurobiology of Rett syndrome. J Child Neurol 18, 688-692.

Jonas P, Bischofberger J \& Sandkuhler J. (1998). Corelease of two fast neurotransmitters at a central synapse. Science $281,419-424$.

Jones PL, Veenstra GJ, Wade PA, Vermaak D, Kass SU, Landsberger N, Strouboulis J \& Wolffe AP. (1998). Methylated DNA and MeCP2 recruit histone deacetylase to repress transcription. Nat Genet 19, 187-191.

Jorde LB, Mason-Brothers A, Waldmann R, Ritvo ER, Freeman BJ, Pingree C, McMahon WM, Petersen B, Jenson WR \& Mo A. (1990). The UCLA-University of Utah epidemiologic survey of autism: genealogical analysis of familial aggregation. Am J Med Genet 36, 85-88.

Julu PO \& Witt Engerstrom I. (2005). Assessment of the maturity-related brainstem functions reveals the heterogeneous phenotypes and facilitates clinical management of Rett syndrome. Brain Dev 27 Suppl 1, S43-S53.

Kanner L. Autistic Disturbances of Affective Contact.Nervous Child 2:217-50, 1943.

Katz B \& Miledi R. (1969). Spontaneous and evoked activity of motor nerve endings in calcium Ringer. J Physiol 203, 689-706.

Kerr AM \& Burford B. (2001). Towards a full life with Rett disorder. Pediatr Rehabil 4, 157-168; discussion 155-156.

Kishi N \& Macklis JD. (2004). MECP2 is progressively expressed in post-migratory neurons and is involved in neuronal maturation rather than cell fate decisions. Mol Cell Neurosci 27, 306-321. 
Koike-Tani M, Saitoh N \& Takahashi T. (2005). Mechanisms underlying developmental speeding in AMPA-EPSC decay time at the calyx of Held. J Neurosci 25, 199-207.

Kozinetz CA, Skender ML, MacNaughton N, Almes MJ, Schultz RJ, Percy AK \& Glaze DG. (1993). Epidemiology of Rett syndrome: a population-based registry. Pediatrics 91, 445-450.

Laumonnier F, Bonnet-Brilhault F, Gomot M, Blanc R, David A, Moizard MP, Raynaud M, Ronce N, Lemonnier E, Calvas P, Laudier B, Chelly J, Fryns JP, Ropers HH, Hamel BC, Andres C, Barthelemy C, Moraine C \& Briault S. (2004). X-linked mental retardation and autism are associated with a mutation in the NLGN4 gene, a member of the neuroligin family. Am J Hum Genet 74, 552-557.

Laurie DJ, Wisden W \& Seeburg PH. (1992). The distribution of thirteen GABAA receptor subunit mRNAs in the rat brain. III. Embryonic and postnatal development. J Neurosci 12, 4151-4172.

Levinson JN, Chery N, Huang K, Wong TP, Gerrow K, Kang R, Prange O, Wang YT \& El-Husseini A. (2005). Neuroligins mediate excitatory and inhibitory synapse formation: involvement of PSD-95 and neurexin-1 beta in neuroligin-induced synaptic specificity. J Biol Chem 280, 17312-17319.

Lewis JD, Meehan RR, Henzel WJ, Maurer-Fogy I, Jeppesen P, Klein F \& Bird A. (1992). Purification, sequence, and cellular localization of a novel chromosomal protein that binds to methylated DNA. Cell 69, 905-914.

Li YM, Shen L, Peever JH \& Duffin J. (2003). Connections between respiratory neurones in the neonatal rat transverse medullary slice studied with cross-correlation. J Physiol 549, 327-332.

Liu Q \& Wong-Riley MT. (2004). Developmental changes in the expression of GABAA receptor subunits alpha1, alpha2, and alpha3 in the rat pre-Botzinger complex. $\mathrm{J}$ Appl Physiol 96, 1825-1831.

Liu Q \& Wong-Riley MT. (2005). Postnatal developmental expressions of neurotransmitters and receptors in various brain stem nuclei of rats. J Appl Physiol 98, 1442-1457.

Liu Q \& Wong-Riley MT. (2006). Developmental changes in the expression of GABAA 
References

receptor subunits alpha1, alpha2, and alpha3 in brain stem nuclei of rats. Brain Res 1098, 129-138.

Llano I, Gonzalez J, Caputo C, Lai FA, Blayney LM, Tan YP \& Marty A. (2000). Presynaptic calcium stores underlie large-amplitude miniature IPSCs and spontaneous calcium transients. Nat Neurosci 3, 1256-1265.

Lowe AA. (1980). The neural regulation of tongue movements. Prog Neurobiol 15, 295-344.

Marty S, Wehrle R \& Sotelo C. (2000). Neuronal activity and brain-derived neurotrophic factor regulate the density of inhibitory synapses in organotypic slice cultures of postnatal hippocampus. J Neurosci 20, 8087-8095.

Matarazzo V, Cohen D, Palmer AM, Simpson PJ, Khokhar B, Pan SJ \& Ronnett GV. (2004). The transcriptional repressor Mecp2 regulates terminal neuronal differentiation. Mol Cell Neurosci 27, 44-58.

McAllister AK. (2007). Dynamic aspects of CNS synapse formation. Annu Rev Neurosci 30, 425-450.

McClellan AM \& Twyman RE. (1999). Receptor system response kinetics reveal functional subtypes of native murine and recombinant human GABAA receptors. $J$ Physiol 515 (Pt 3), 711-727.

McKay LC, Janczewski WA \& Feldman JL. (2005). Sleep-disordered breathing after targeted ablation of preBotzinger complex neurons. Nat Neurosci 8, 1142-1144.

McKinney RA, Capogna M, Durr R, Gahwiler BH \& Thompson SM. (1999). Miniature synaptic events maintain dendritic spines via AMPA receptor activation. Nat Neurosci 2, 44-49.

McMahon HT, Bolshakov VY, Janz R, Hammer RE, Siegelbaum SA \& Sudhof TC. (1996). Synaptophysin, a major synaptic vesicle protein, is not essential for neurotransmitter release. Proc Natl Acad Sci U S A 93, 4760-4764.

Megias M, Emri Z, Freund TF \& Gulyas Al. (2001). Total number and distribution of inhibitory and excitatory synapses on hippocampal CA1 pyramidal cells. Neuroscience 102, 527-540. 
Micheva KD \& Beaulieu C. (1996). Quantitative aspects of synaptogenesis in the rat barrel field cortex with special reference to GABA circuitry. J Comp Neurol 373, 340-354.

Missler M, Zhang W, Rohlmann A, Kattenstroth G, Hammer RE, Gottmann K \& Sudhof TC. (2003). Alpha-neurexins couple Ca2+ channels to synaptic vesicle exocytosis. Nature 423, 939-948.

Monyer H, Burnashev N, Laurie DJ, Sakmann B \& Seeburg PH. (1994). Developmental and regional expression in the rat brain and functional properties of four NMDA receptors. Neuron 12, 529-540.

Moretti P, Levenson JM, Battaglia F, Atkinson R, Teague R, Antalffy B, Armstrong D, Arancio O, Sweatt JD \& Zoghbi HY. (2006). Learning and memory and synaptic plasticity are impaired in a mouse model of Rett syndrome. J Neurosci 26, 319327.

Muhle R, Trentacoste SV \& Rapin I. (2004). The genetics of autism. Pediatrics 113, e472-486.

Mullaney BC, Johnston MV \& Blue ME. (2004). Developmental expression of methylCpG binding protein 2 is dynamically regulated in the rodent brain. Neuroscience 123, 939-949.

Nabekura J, Katsurabayashi S, Kakazu Y, Shibata S, Matsubara A, Jinno S, Mizoguchi Y, Sasaki A \& Ishibashi H. (2004). Developmental switch from GABA to glycine release in single central synaptic terminals. Nat Neurosci 7, 17-23.

Nan X, Campoy FJ \& Bird A. (1997). MeCP2 is a transcriptional repressor with abundant binding sites in genomic chromatin. Cell 88, 471-481.

Nan X, Ng HH, Johnson CA, Laherty CD, Turner BM, Eisenman RN \& Bird A. (1998). Transcriptional repression by the methyl-CpG-binding protein MeCP2 involves a histone deacetylase complex. Nature 393, 386-389.

Nelson ED, Kavalali ET \& Monteggia LM. (2006). MeCP2-dependent transcriptional repression regulates excitatory neurotransmission. Curr Biol 16, 710-716. 
Nelson ED, Kavalali ET \& Monteggia LM. (2008). Activity-dependent suppression of miniature neurotransmission through the regulation of DNA methylation. J Neurosci 28, 395-406.

Nikitina T, Ghosh RP, Horowitz-Scherer RA, Hansen JC, Grigoryev SA \& Woodcock CL. (2007). MeCP2-chromatin interactions include the formation of chromatosomelike structures and are altered in mutations causing Rett syndrome. J Biol Chem 282, 28237-28245.

Nomura Y. (2005). Early behavior characteristics and sleep disturbance in Rett syndrome. Brain Dev 27 Suppl 1, S35-S42.

Nusser Z, Sieghart W, Benke D, Fritschy JM \& Somogyi P. (1996). Differential synaptic localization of two major gamma-aminobutyric acid type $A$ receptor alpha subunits on hippocampal pyramidal cells. Proc Natl Acad Sci U S A 93, 1193911944.

O’Brien RJ, Kamboj S, Ehlers MD, Rosen KR, Fischbach GD \& Huganir RL. (1998). Activity-dependent modulation of synaptic AMPA receptor accumulation. Neuron 21, 1067-1078.

Okada M, Onodera K, Van Renterghem C, Sieghart W \& Takahashi T. (2000). Functional correlation of GABA(A) receptor alpha subunits expression with the properties of IPSCs in the developing thalamus. J Neurosci 20, 2202-2208.

Paarmann I, Frermann D, Keller BU \& Hollmann M. (2000). Expression of 15 glutamate receptor subunits and various splice variants in tissue slices and single neurons of brainstem nuclei and potential functional implications. J Neurochem 74, 1335-1345.

Paarmann I, Frermann D, Keller BU, Villmann C, Breitinger HG \& Hollmann M. (2005). Kinetics and subunit composition of NMDA receptors in respiratory-related neurons. J Neurochem 93, 812-824.

Pelka GJ, Watson CM, Radziewic T, Hayward M, Lahooti H, Christodoulou J \& Tam PP. (2006). Mecp2 deficiency is associated with learning and cognitive deficits and altered gene activity in the hippocampal region of mice. Brain 129, 887-898. 
Persico AM \& Bourgeron T. (2006). Searching for ways out of the autism maze: genetic, epigenetic and environmental clues. Trends Neurosci 29, 349-358.

Picker JD, Yang R, Ricceri L \& Berger-Sweeney J. (2006). An altered neonatal behavioral phenotype in Mecp2 mutant mice. Neuroreport 17, 541-544.

Prange O, Wong TP, Gerrow K, Wang YT \& El-Husseini A. (2004). A balance between excitatory and inhibitory synapses is controlled by PSD-95 and neuroligin. Proc Natl Acad Sci U S A 101, 13915-13920.

Rett A. (1966). [On a unusual brain atrophy syndrome in hyperammonemia in childhood]. Wien Med Wochenschr 116, 723-726.

Richter DW \& Spyer KM. (2001). Studying rhythmogenesis of breathing: comparison of in vivo and in vitro models. Trends Neurosci 24, 464-472.

Ritter B \& Zhang W. (2000). Early postnatal maturation of GABAA-mediated inhibition in the brainstem respiratory rhythm-generating network of the mouse. Eur J Neurosci 12, 2975-2984.

Ritvo ER, Freeman BJ, Mason-Brothers A, Mo A \& Ritvo AM. (1985). Concordance for the syndrome of autism in 40 pairs of afflicted twins. Am J Psychiatry 142, 7477.

Ritvo ER, Mason-Brothers A, Menkes JH \& Sparkes RS. (1988). Association of autism, retinoblastoma, and reduced esterase D activity. Arch Gen Psychiatry 45, 600.

Rosenmund C \& Stevens CF. (1996). Definition of the readily releasable pool of vesicles at hippocampal synapses. Neuron 16, 1197-1207.

Rudolph U \& Mohler H. (2004). Analysis of GABAA receptor function and dissection of the pharmacology of benzodiazepines and general anesthetics through mouse genetics. Annu Rev Pharmacol Toxicol 44, 475-498.

Samaco RC, Hogart A \& LaSalle JM. (2005). Epigenetic overlap in autism-spectrum 
References

neurodevelopmental disorders: MECP2 deficiency causes reduced expression of UBE3A and GABRB3. Hum Mol Genet 14, 483-492.

Sans N, Petralia RS, Wang YX, Blahos J, 2nd, Hell JW \& Wenthold RJ. (2000). A developmental change in NMDA receptor-associated proteins at hippocampal synapses. J Neurosci 20, 1260-1271.

Santos M, Silva-Fernandes A, Oliveira P, Sousa N \& Maciel P. (2007). Evidence for abnormal early development in a mouse model of Rett syndrome. Genes Brain Behav 6, 277-286.

Savelyeva L, Sagulenko E, Schmitt JG \& Schwab M. (2006). The neurobeachin gene spans the common fragile site FRA13A. Hum Genet 118, 551-558.

Scheiffele P, Fan J, Choih J, Fetter R \& Serafini T. (2000). Neuroligin expressed in nonneuronal cells triggers presynaptic development in contacting axons. Cell 101, 657-669.

Shahbazian M, Young J, Yuva-Paylor L, Spencer C, Antalffy B, Noebels J, Armstrong D, Paylor R \& Zoghbi H. (2002a). Mice with truncated MeCP2 recapitulate many Rett syndrome features and display hyperacetylation of histone H3. Neuron 35, 243-254.

Shahbazian MD, Antalffy B, Armstrong DL \& Zoghbi HY. (2002b). Insight into Rett syndrome: MeCP2 levels display tissue- and cell-specific differences and correlate with neuronal maturation. Hum Mol Genet 11, 115-124.

Smalley SL. (1997). Genetic influences in childhood-onset psychiatric disorders: autism and attention-deficit/hyperactivity disorder. Am J Hum Genet 60, 12761282.

Smith JC, Ellenberger HH, Ballanyi K, Richter DW \& Feldman JL. (1991). PreBotzinger complex: a brainstem region that may generate respiratory rhythm in mammals. Science 254, 726-729.

Song JY, Ichtchenko K, Sudhof TC \& Brose N. (1999). Neuroligin 1 is a postsynaptic cell-adhesion molecule of excitatory synapses. Proc Natl Acad Sci U S A 96, $1100-$ 1105. 


\section{References}

Stettner GM, Huppke P, Brendel C, Richter DW, Gartner J \& Dutschmann M. (2007). Breathing dysfunctions associated with impaired control of postinspiratory activity in Mecp2-/y knockout mice. J Physiol 579, 863-876.

Stocca G \& Vicini S. (1998). Increased contribution of NR2A subunit to synaptic NMDA receptors in developing rat cortical neurons. J Physiol 507 (Pt 1), 13-24.

Stuart G, Spruston N, Sakmann B \& Hausser M. (1997). Action potential initiation and backpropagation in neurons of the mammalian CNS. Trends Neurosci 20, 125131.

Su Y, Balice-Gordon RJ, Hess DM, Landsman DS, Minarcik J, Golden J, Hurwitz I, Liebhaber SA \& Cooke NE. (2004). Neurobeachin is essential for neuromuscular synaptic transmission. J Neurosci 24, 3627-3636.

Sudhof TC. (2004). The synaptic vesicle cycle. Annu Rev Neurosci 27, 509-547.

Sutton MA, Wall NR, Aakalu GN \& Schuman EM. (2004). Regulation of dendritic protein synthesis by miniature synaptic events. Science 304, 1979-1983.

Swann JW, Le JT, Lam TT, Owens J \& Mayer AT. (2007). The impact of chronic network hyperexcitability on developing glutamatergic synapses. Eur J Neurosci 26, 975-991.

Tabuchi K, Blundell J, Etherton MR, Hammer RE, Liu X, Powell CM \& Sudhof TC. (2007). A neuroligin-3 mutation implicated in autism increases inhibitory synaptic transmission in mice. Science 318, 71-76.

Tafoya LC, Mameli M, Miyashita T, Guzowski JF, Valenzuela CF \& Wilson MC. (2006). Expression and function of SNAP-25 as a universal SNARE component in GABAergic neurons. J Neurosci 26, 7826-7838.

Takahashi T. (2005). Postsynaptic receptor mechanisms underlying developmental speeding of synaptic transmission. Neurosci Res 53, 229-240.

Takamori S, Holt M, Stenius K, Lemke EA, Gronborg M, Riedel D, Urlaub H, Schenck S, Brugger B, Ringler P, Muller SA, Rammner B, Grater F, Hub JS, De Groot BL, Mieskes G, Moriyama Y, Klingauf J, Grubmuller H, Heuser J, Wieland F \& Jahn R. 


\section{References}

(2006). Molecular anatomy of a trafficking organelle. Cell 127, 831-846.

Thoby-Brisson M, Cauli B, Champagnat J, Fortin G \& Katz DM. (2003). Expression of functional tyrosine kinase $B$ receptors by rhythmically active respiratory neurons in the pre-Botzinger complex of neonatal mice. J Neurosci 23, 7685-7689.

Tokumasu M, Nakazono Y, Ide H, Akagawa K \& Onimaru H. (2001). Optical recording of spontaneous respiratory neuron activity in the rat brain stem. Jpn J Physiol 51, 613-619.

Townsend M, Yoshii A, Mishina M \& Constantine-Paton M. (2003). Developmental loss of miniature N-methyl-D-aspartate receptor currents in NR2A knockout mice. Proc Natl Acad Sci U S A 100, 1340-1345.

Trevarthen C \& Daniel S. (2005). Disorganized rhythm and synchrony: early signs of autism and Rett syndrome. Brain Dev 27 Suppl 1, S25-S34.

Turrigiano GG, Leslie KR, Desai NS, Rutherford LC \& Nelson SB. (1998). Activitydependent scaling of quantal amplitude in neocortical neurons. Nature 391, 892896.

Turrigiano GG \& Nelson SB. (2004). Homeostatic plasticity in the developing nervous system. Nat Rev Neurosci 5, 97-107.

Varoqueaux F, Aramuni G, Rawson RL, Mohrmann R, Missler M, Gottmann K, Zhang W, Sudhof TC \& Brose N. (2006). Neuroligins determine synapse maturation and function. Neuron 51, 741-754.

Varoqueaux F, Jamain S \& Brose N. (2004). Neuroligin 2 is exclusively localized to inhibitory synapses. Eur J Cell Biol 83, 449-456.

Varoqueaux F, Sigler A, Rhee JS, Brose N, Enk C, Reim K \& Rosenmund C. (2002). Total arrest of spontaneous and evoked synaptic transmission but normal synaptogenesis in the absence of Munc13-mediated vesicle priming. Proc Natl Acad Sci U S A 99, 9037-9042.

Varoqueaux F, Sons MS, Plomp JJ \& Brose N. (2005). Aberrant morphology and residual transmitter release at the Munc13-deficient mouse neuromuscular synapse. Mol Cell Biol 25, 5973-5984. 
Vicini S, Wang JF, Li JH, Zhu WJ, Wang YH, Luo JH, Wolfe BB \& Grayson DR. (1998). Functional and pharmacological differences between recombinant $\mathrm{N}$-methylD-aspartate receptors. J Neurophysiol 79, 555-566.

Viemari JC, Roux JC, Tryba AK, Saywell V, Burnet H, Pena F, Zanella S, Bevengut M, Barthelemy-Requin M, Herzing LB, Moncla A, Mancini J, Ramirez JM, Villard L \& Hilaire G. (2005). Mecp2 deficiency disrupts norepinephrine and respiratory systems in mice. J Neurosci 25, 11521-11530.

Wang X, Herberg FW, Laue MM, Wullner C, Hu B, Petrasch-Parwez E \& Kilimann MW. (2000). Neurobeachin: A protein kinase A-anchoring, beige/Chediak-higashi protein homolog implicated in neuronal membrane traffic. J Neurosci 20, 85518565.

Washbourne P, Thompson PM, Carta M, Costa ET, Mathews JR, Lopez-Bendito G, Molnar Z, Becher MW, Valenzuela CF, Partridge LD \& Wilson MC. (2002). Genetic ablation of the t-SNARE SNAP-25 distinguishes mechanisms of neuroexocytosis. Nat Neurosci 5, 19-26.

Watase K \& Zoghbi HY. (2003). Modelling brain diseases in mice: the challenges of design and analysis. Nat Rev Genet 4, 296-307.

World Health Organization. The ICD-10 Classification of Mental and Behavioural Disorders: Clinical Descriptions and Diagnostic Guidelines. Geneva, Switzerland: World Health Organization; 1992

Yamada MK, Nakanishi K, Ohba S, Nakamura T, Ikegaya Y, Nishiyama N \& Matsuki N. (2002). Brain-derived neurotrophic factor promotes the maturation of GABAergic mechanisms in cultured hippocampal neurons. J Neurosci 22, 7580-7585.

Yamashita Y, Matsuishi T, Ishibashi M, Kimura A, Onishi Y, Yonekura Y \& Kato H. (1998). Decrease in benzodiazepine receptor binding in the brains of adult patients with Rett syndrome. J Neurol Sci 154, 146-150.

Zhang L, He J, Jugloff DG \& Eubanks JH. (2008). The MeCP2-null mouse hippocampus displays altered basal inhibitory rhythms and is prone to hyperexcitability. Hippocampus 18, 294-309. 
References

Zhang W, Elsen F, Barnbrock A \& Richter DW. (1999). Postnatal development of GABAB receptor-mediated modulation of voltage-activated $\mathrm{Ca} 2+$ currents in mouse brain-stem neurons. Eur J Neurosci 11, 2332-2342.

Zhang W, Rohlmann A, Sargsyan V, Aramuni G, Hammer RE, Sudhof TC \& Missler M. (2005). Extracellular domains of alpha-neurexins participate in regulating synaptic transmission by selectively affecting $\mathrm{N}$ - and P/Q-type Ca2+ channels. J Neurosci $25,4330-4342$.

Zoghbi HY. (2003). Postnatal neurodevelopmental disorders: meeting at the synapse? Science 302, 826-830. 


\section{Acknowledgements}

\section{Acknowledgements}

First, I would like to express my gratitude to my supervisor, Weiqi Zhang, for offering me the opportunity to work in his lab, for all the discussions we had and the guidance he gave me during these years and also for the patience he dealt with my impossible working hours.

I would like to thank to my other two supervisors and collaborators, Nils Brose and Markus Missler, for all the input they gave to my project and for being open and available whenever I needed them.

Special thanks to my colleagues and friends that started in this program with me or that I have met on the way, people that supported me and with whom I shared the goods and the bads of the life of a PhD student. Thank you Stephan, Felipe, Katarina, Andrea, Kamila, Sonia, Ben, Lila, and especially Alex, which made my $\mathrm{PhD}$ seem much more easier than it was.

At the end I would like to thank to my long time friends, Simona and Catalin, for their constant support and love, and also to the people to whom I owe my life itself: to my mother Marcela, to my grandmother Eleonora and to my uncle Lucian. 


\section{Curriculum vitae}

Personal data:

Name: Lucian Adrian Medrihan

Date of birth: $\quad 22.11 .1978$

Place of birth: Bucharest, Romania

Nationality: Romanian

Address: $\quad$ Mauerstrasse 32, D-37073, Göttingen, Germany

Mail address: Imedrik@gwdg.de

Phones: $\quad$ +49-551-9995362 (home)/+49-1601802208 (mobile)

Education:

2004-2008

PhD in Neurosciences, University of Göttingen, Germany

2003-2004 International Max-Planck Research School for Neuroscience, Göttingen, Germany

1999-2003

Faculty of Biology, University of Bucharest, Romania

1993-1997

National College "Cantemir-Voda", Bucharest, Romania

Scholarships:

2005-present

Lichtenberg Stipend from the State of Lower Saxony

2003-2004

Max-Planck Scholarship

2000-2002

University of Bucharest Scholarship 


\section{Publications}

Papers:

"Early defects of GABAergic synapses in the brain stem of a MeCP2 mouse model of Rett syndrome" Medrihan L., Tantalaki E., Aramuni G., Sargsyan V., Dudanova I., Missler M. and Zhang W. J. Neurophysiology, 2008, Jan; 99(1): $112-21$

"Neurobeachin is required for the formation and function of central excitatory and inhibitory synapses" Medrihan L., Rohlmann A., Fairless R., Missler M., Zhang W. and Kilimann M.W. Journal of Neuroscience, under review.

"Erythropoietin enhances hippocampal long-term potentiation and memory" Adamcio B., Sargin D., Stradomska A., Medrihan L., Gertler C., Theis F., Zhang M., Müller M., Hassouna I., Hannke K., Sperling S., Radyushkin K., El Kordi A., Ronnenberg A., Wolf F., Brose N., Rhee J.S., Zhang W., and Ehrenreich H. BMC Biology, 2008, September; 6: 37.

\section{Abstracts:}

Medrihan L., Aramuni G., Varoqueaux F, Brose N. and Zhang W. (2005). "Neuroligins are essential for neuronal network function in the respiratory network of mice" Pflügers Archiv 449 (Suppl. 1): S86

L. Medrihan, R. Fairless, M. Missler, M. W. Kilimann and W.Zhang (2006). "Neurobeachin is essential for inhibitory synaptic transmission" Acta Physiologica 186 (Suppl. 1): p. 134

L. Medrihan, W. Zhang (2006). "Deletion of MeCP2 causes progressive GABAergic and glutamatergic dysbalance in early postnatal stage of mouse" FENS Abstr., vol.3, A026.16, 2006 